
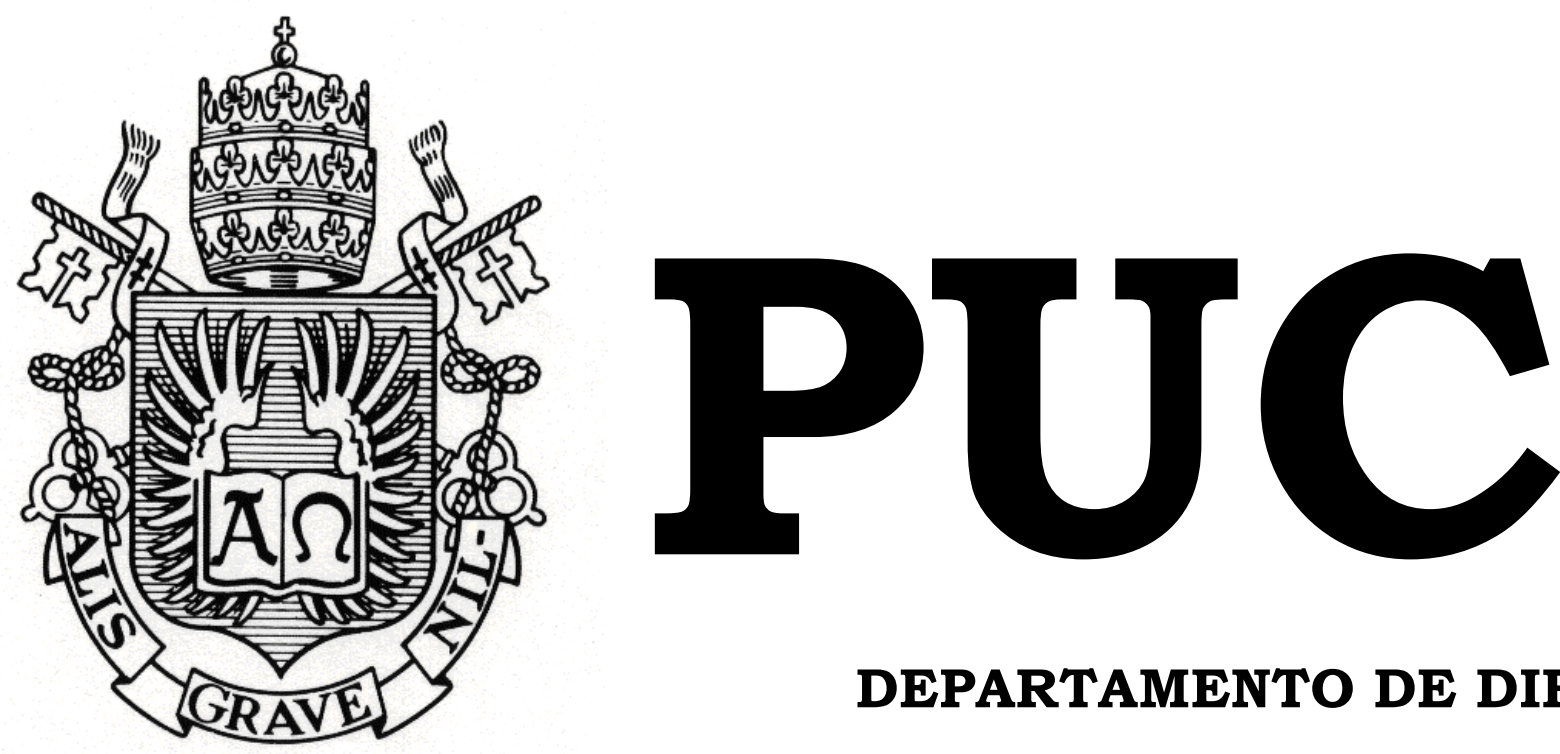

DEPARTAMENTO DE DIREITO

\title{
O seguro de responsabilidade civil de administradores à luz da nova regulamentação da SUSEP
}

por

Carolina Estarque da Cunha

ORIENTADOR(A): Pablo Waldemar Renteria

2017.2

PONTIFÍCIA UNIVERSIDADE CATÓLICA DO RIO DE JANEIRO

RUA MARQUÊS DE SÃO VICENTE, 225 - CEP 22453-900

RIO DE JANEIRO - BRASIL 


\title{
O seguro de responsabilidade civil de administradores à luz da nova regulamentação da SUSEP
}

\author{
por
}

Carolina Estarque da Cunha

Monografia apresentada ao

Departamento de Direito da

Pontificia Universidade Católica do

Rio de Janeiro (PUC-Rio) para a obtenção do Título de Bacharel em Direito.

Orientador(a): Pablo Waldemar Renteria 
Ao meu tio, Francisco Estarque, por todo o amor e por ter tornado essa jornada um caminho possível. 


\section{Agradecimentos}

Em primeiro lugar, agradeço à pessoa sem a qual nada disso seria possível: minha mãe, Fátima, pelo amor e apoio incondicionais em todos os momentos e por ter vivido comigo essa jornada, do início ao fim.

Ao meu pai, Neto, por desde cedo me incentivar a buscar o meu melhor.

Ao meu amor e melhor amigo, Flávio, pelo companheirismo, compreensão e carinho. Não poderia deixar de agradecer, ainda, pela grande ajuda com este projeto e por ter me "apresentado" ao direito.

À minha família, pelos valores que me foram transmitidos, pela compreensão e apoio irrestritos e por estarem tão presentes em mim.

Às minhas amigas de sempre, Ana Paula Mello, Ana Paula Couto, Carolina Coelho, Elisa Pessoa e Luiza Ribeiro, por compartilharem comigo as melhores recordações e por permanecerem tão presentes na minha vida.

Aos amigos da PUC/RJ, em especial, André Milech, Bruna Mello, Isabella Estabile, Juliana Mathias, Mariele Milhorance e Victoria Bottrel, por compartilharem comigo estes últimos cinco anos e contribuírem para que esse período representasse algo tão especial.

Por fim, mas não menos importante, agradeço ao meu orientador, Pablo Renteria, pela confiança, aprendizado e pela oportunidade de ter sido sua aluna, estagiária e orientanda. 


\section{Resumo}

CUNHA, Carolina Estarque da. O seguro de responsabilidade civil de administradores à luz da nova regulamentação da SUSEP. 121 p. Monografia (Graduação em Direito) - Pontifícia Universidade Católica do Rio de Janeiro: Rio de Janeiro, 2017.

$\mathrm{O}$ presente trabalho tem por objetivo analisar o seguro de responsabilidade civil de administradores sob o enfoque do novo regime regulatório trazido pela Circular SUSEP $n^{\circ}$ 553/2017, ressaltando as aproximações e os distanciamentos das novas regras às práticas de mercado até então adotadas pelas seguradoras, bem como avaliando a sua adequação às necessidades das companhias tomadoras e de seus administradores. Para tanto, serão apresentados os aspectos gerais do contrato de seguro, notadamente a estrutura técnico-econômica que serve de base às operações securitárias e os elementos desta modalidade contratual. Em seguida, a partir da análise do regime legal de responsabilidade dos administradores, serão delimitados os riscos aos quais estão expostos estes profissionais em razão da função por eles desempenhada na gestão de sociedades anônimas. Abordar-se-ão as disposições referentes à responsabilidade dos administradores nos âmbitos cível, administrativo e penal, com destaque às disposições da Lei $\mathrm{n}^{\mathrm{o}}$ 6.404/76 e à regulação do mercado de valores mobiliários. Ao final, serão descritas as principais disposições da nova regulamentação editada pela Superintendência de Seguros Privados SUSEP no que diz respeito às partes envolvidas no seguro de responsabilidade civil de administradores, a modalidade de apólice adotada, a cobertura securitária e as hipóteses de exclusão e os limites de garantia.

Palavras Chave: Direito Securitário - Direito Societário - Mercado de Valores Mobiliários - Responsabilidade Civil - Responsabilidade Administrativa - Sociedades Anônimas - Seguro de Responsabilidade Civil de Administradores - Seguro D\&O - Superintendência de Seguros Privados - Circular SUSEP no 553/2017. 


\section{SUMÁRIO}

INTRODUÇÃ O …......................................................................

CAPÍTULO 1 - ASPECTOS GERAIS DAS OPERAÇÕES DE

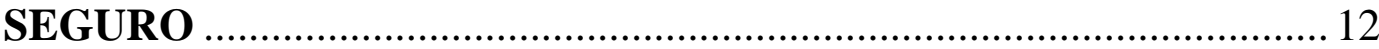

1.1. O contrato de seguro como instrumento de prevenção de riscos... 12

1.2. Fundamentos técnicos das operações de seguro ............................. 15

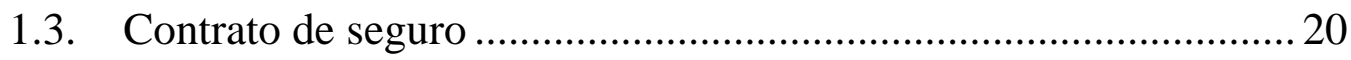

1.3.1. Aspectos jurídicos do contrato ............................................... 20

1.3.2. Elementos do contrato .............................................................. 24

1.3.2.1. Interesse Legítimo ........................................................... 24

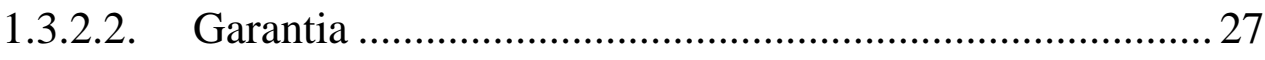

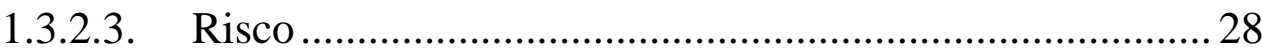

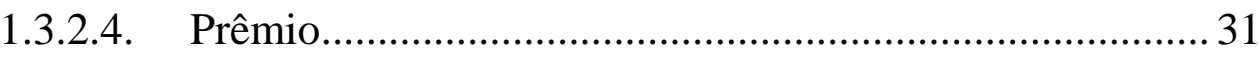

1.3.3. Aplicação da máxima boa-fé no contrato de seguro ................ 32 CAPÍTULO 2 - O REGIME LEGAL DE RESPONSABILIDADE DOS

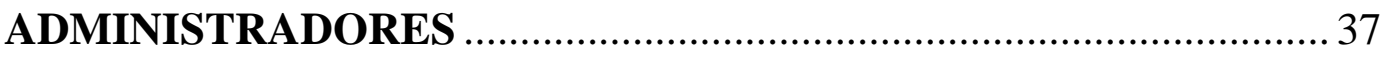

2.1. As esferas de responsabilização do administrador .......................... 38

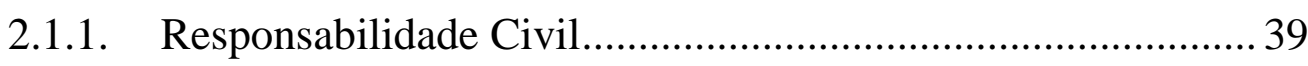

2.1.1.1. A responsabilidade civil dos administradores na Lei das S.A. 40

2.1.2. Responsabilidade Administrativa............................................... 54

2.1.2.1. Aspectos da responsabilidade administrativa .......................57 57

2.1.2.2. O papel da CVM na regulação do mercado de valores

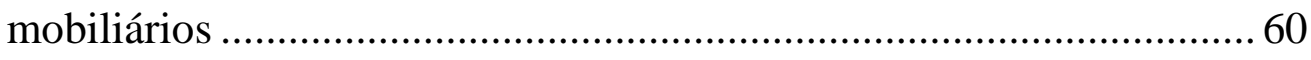

2.1.2.3. O termo de compromisso no âmbito da CVM...................... 63

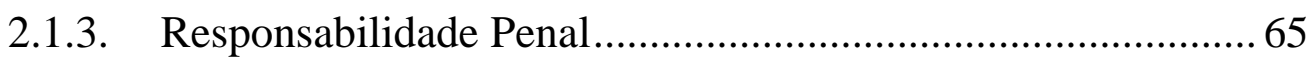

CAPÍTULO 3 - O SEGURO D\&O E A REGULAMENTAÇÃO DA

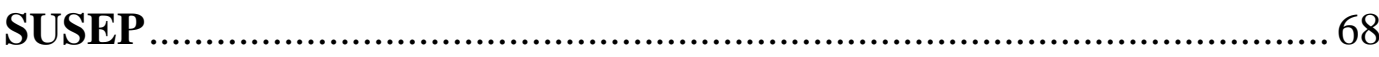

3.1. A relevância do seguro $\mathrm{D} \& \mathrm{O}$ como instrumento de tutela de

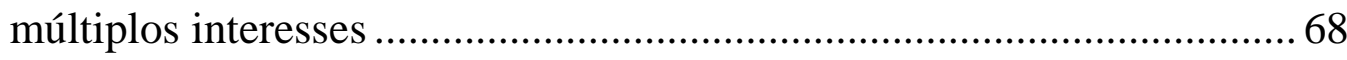

3.2. Intervenção do Estado na atividade securitária: o papel da SUSEP 72

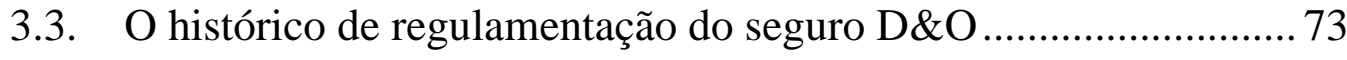


3.4. O regime regulatório da Circular SUSEP $\mathrm{n}^{\circ}$ 553/2017................ 81

3.4.1. Apólice à base de reclamação (claim made basis)................. 83

3.4.2. Tomador e Segurado ........................................................... 85

3.4.3. Garantia e Cobertura Securitária........................................... 88

3.4.4. Exclusões de Cobertura................................................... 97

3.4.5. Limite Máximo de Indenização (LMI), Limite Agregado (LA) e Limite Máximo de Garantia (LMG) ............................................. 102

3.4.6. Direito de reembolso ou pagamento direto a terceiro ........... 103

3.5. O risco moral (moral hazard) .............................................. 105

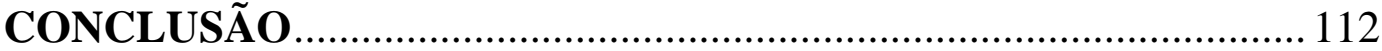

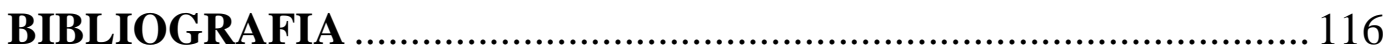




\section{INTRODUÇÃO}

Em um cenário em que o fenômeno de dissociação entre a propriedade e a gestão social se intensifica, o papel desempenhado pelos administradores na condução dos negócios sociais é cada vez mais relevante, o que se reflete na ampliação dos poderes e atribuições conferidos a tais profissionais.

No entanto, em contrapartida ao alargamento de suas funções, o legislador estabeleceu algumas limitações à atuação dos administradores, fixadas a partir de um regime legal que procura equilibrar deveres e responsabilidades, de modo a coibir abusos e condutas alheias ao interesse social, bem como resguardar os interesses de terceiros que se relacionem com a sociedade.

Em razão da complexidade das relações econômicas e da influência que a sociedade empresária exerce em seu meio social, as decisões negociais tomadas no âmbito interno da sociedade repercutem na esfera de interesses de diversos indivíduos (acionistas, consumidores, credores, empregados, prestadores de serviços, etc.), razão pela qual o regime legal de responsabilidade atribuído ao administrador se estende por diversas esferas do direito (societária, administrativa, consumerista, trabalhista, falimentar, tributária, criminal, previdenciária e ambiental).

Desse modo, se, por um lado, a opção por assumir riscos e tomar decisões ousadas e criativas é o que impulsiona a atividade econômica e o que se espera de administradores qualificados e comprometidos com a realização do objetivo social, por outro, a extensão dos deveres e responsabilidades a eles impostos pode incentivar uma gestão excessivamente conservadora.

Neste cenário, o seguro de responsabilidade civil de administradores, também conhecido como seguro D\&O (Directors' and Officers '), desponta 
como um instrumento apto a harmonizar os diferentes interesses envolvidos na gestão social.

Trata-se de modalidade de seguro usualmente contratada pela própria sociedade por meio de apólice coletiva em benefício de seus administradores, visando garantir o interesse legítimo destes últimos de ter o seu patrimônio pessoal resguardado de eventuais efeitos econômicos negativos decorrentes de sua responsabilização.

Por esta razão, além de conferir maior segurança aos administradores para a assunção de riscos na condução dos negócios sociais, a contratação do seguro D\&O contribui para a atração de profissionais capacitados para ocupar cargos na administração da sociedade, de modo que esta modalidade de seguro pode figurar como instrumento de remuneração indireta do administrador.

Diante das limitações do patrimônio pessoal do administrador para recomposição dos prejuízos causados em decorrência de atos praticados na gestão social, o seguro D\&O atende ainda os interesses dos sujeitos lesados, uma vez que a reparação dos danos será assegurada não apenas por um único patrimônio, mas pelos recursos constantes de fundo comum, constituído a partir das contribuições individuais de cada um dos tomadores do seguro e administrado pela seguradora.

Em vista de sua capacidade de conciliar interesses distintos e do estímulo conferido a administrações ousadas e criativas, o seguro de responsabilidade civil de administradores vem ganhando cada vez mais espaço no mercado brasileiro.

À luz das evoluções do mercado e das modificações no regime legal de responsabilidade dos administradores, as condições de contratação, as situações objeto de cobertura e os procedimentos de análise de risco adotados para o seguro D\&O vinham sendo desenvolvidos e aprimorados 
pelas próprias seguradoras conforme as necessidades dos agentes econômicos.

No entanto, o aumento da sinistralidade decorrente, em parte, da intensificação das investigações realizadas pela polícia federal no âmbito da operação Lava Jato e da recessão econômica vivenciada nos últimos anos, e, em parte, do próprio crescimento do mercado securitário, levantou questionamentos quanto à necessidade de delimitar a cobertura do seguro D\&O e afastar expressamente a sua garantia para determinados riscos.

Nessa esteira, verificou-se um esforço da Superintendência de Seguros Privados - SUSEP, entidade responsável pela fiscalização e supervisão do mercado securitário privado brasileiro, para estabelecer diretrizes gerais aplicáveis ao seguro de responsabilidade civil de administradores, que, até a edição da Circular SUSEP $n^{\circ}$ 541, de 14 de outubro de 2016 posteriormente substituída pela Circular SUSEP n ${ }^{\circ} 553$, de 23 de maio de 2017 -, não era objeto de regulamentação específica, sendo regido pelas normas gerais aplicáveis aos seguros de responsabilidade civil.

Assim, o presente estudo tem por objetivo analisar as principais disposições trazidas pela regulamentação do seguro D\&O e o potencial impacto dessas novas regras sobre as práticas de mercado que, até então, vinham sendo adotadas pelas seguradoras e pelos demais agentes de mercado, com especial atenção à adequação desta nova regulamentação às necessidades dos indivíduos segurados e das sociedades tomadoras.

Para tanto, este trabalho será dividido em três capítulos: (i) breve análise dos aspectos gerais do contrato de seguro; (ii) exposição do regime legal de responsabilidade dos administradores; e (iii) descrição das principais características do seguro D\&O e análise do regime regulatório da Circular SUSEP n ${ }^{\circ} 553 / 2017$.

Em um primeiro momento, serão apresentados os aspectos gerais do contrato de seguro, com destaque para a estrutura técnico-econômica que 
viabiliza as operações de seguro a partir do mapeamento e pulverização de riscos, bem como para os elementos que são, tradicionalmente, apontados como integrantes desta modalidade contratual, quais sejam, (i) o interesse segurável; (ii) a garantia; (iii) o risco; e (iv) o prêmio.

Em um segundo momento, será apresentado o regime legal de responsabilidade dos administradores, de forma a evidenciar e delimitar os riscos aos quais estão expostos os administradores em razão de sua atuação na gestão social e que, eventualmente, poderão ser objeto de garantia pelo seguro $\mathrm{D} \& \mathrm{O}$ ou que estarão expressamente excluídos da cobertura securitária.

Esclarece-se, no entanto, que não obstante a multiplicidade de normas jurídicas aplicáveis aos administradores de companhias, serão abordados neste estudo os três planos de destaque em que são projetadas as responsabilidades dos administradores: civil, administrativo e penal.

Vale ressaltar que o enfoque do presente trabalho é a contratação do seguro de responsabilidade civil de administradores por sociedades anônimas, fechadas e abertas, razão pela qual serão apresentadas as disposições específicas da Lei $n^{0}$ 6.404, de 15 de dezembro de 1976 ("Lei das S.A.") para fins de apuração da responsabilidade civil do administrador.

Ademais, muito embora se reconheça que a responsabilidade administrativa dos diretores e conselheiros perpassa a atuação de diferentes entidades reguladoras, tais como o Conselho Administrativo de Defesa Econômica - CADE e o Banco Central do Brasil, bem como a apuração de responsabilidade em matéria tributária e ambiental, o presente estudo se limitará a analisar o regime de responsabilidade decorrente da atuação da Comissão de Valores Mobiliários - CVM, entidade responsável pela fiscalização de companhias abertas, de forma que não será objeto de análise a conduta de administradores em instituições financeiras ou a responsabilidade decorrente da legislação concorrencial. 
Por fim, o terceiro capítulo enfrentará o tema central objeto deste trabalho: o regime regulatório trazido pela Circular SUSEP n ${ }^{\circ}$ 553/2017. Além de apresentar as novas regras aplicáveis ao seguro D\&O, procura-se analisar o seu distanciamento das práticas de mercado até então adotadas pelas seguradoras em suas apólices, bem como avaliar a sua adequação às necessidades das companhias tomadoras e de seus administradores.

Cumpre observar que as principais características do seguro D\&O, tal como a espécie de apólice adotada (apólice à base de ocorrências ou à base de reclamações), as pessoas destinatárias da garantia do seguro ("segurados"), a cobertura securitária e as hipóteses de exclusão ou limitação de garantia, serão abordadas à luz das disposições da nova regulamentação.

Desse modo, ressalta-se que o presente trabalho não busca esgotar o tema, que apresenta inúmeras particularidades e desdobramentos, ou tampouco discorrer sobre todos os aspectos desta modalidade de seguro, mas tão apenas apresentar uma avaliação das alterações e inovações propostas pela SUSEP em sua regulamentação.

Por último, ressalta-se que todas as considerações apresentadas quanto aos potenciais efeitos decorrentes dessa nova regulamentação no mercado partem de uma análise teórica, haja vista que a Circular SUSEP nº 553/2017 concedeu o prazo de cento e oitenta dias para que as seguradoras possam ajustar as apólices já comercializadas, de modo que somente com a submissão de novos pedidos de registro pelas seguradoras será possível avaliar o entendimento da SUSEP quanto a determinadas regras da nova circular. 


\section{CAPÍTULO 1 - ASPECTOS GERAIS DAS OPERAÇÕES DE SEGURO}

\subsection{O contrato de seguro como instrumento de prevenção de riscos}

Muito embora os riscos tenham se notado presentes durante toda a história do desenvolvimento humano, é certo que o avanço econômico, a maior complexidade das relações comerciais e as transformações cientifico tecnológicas guardam relação direta com a maior exposição a riscos vivenciada pela sociedade atual, apontada por alguns autores como a "sociedade de risco" 1 .

Ainda que se admita que os riscos são indissociáveis do progresso humano e, em especial, das atividades econômicas, nem por isso deixam de representar externalidades negativas que impactam não somente a atuação dos agentes econômicos, como também, e talvez ainda mais claramente, as relações diárias em sociedade ${ }^{2}$.

A intensificação dos riscos foi acompanhada de um esforço criativo por parte de estudiosos que se dedicaram à compreensão deste elemento e à análise de suas consequências e, por conseguinte, contribuíram para o desenvolvimento de instrumentos voltados à prevenção do risco e à administração dos efeitos danosos dele decorrentes, entre os quais, o contrato de seguro ${ }^{3}$.

\footnotetext{
${ }^{1}$ BECK, Ulrich. Sociedade de Risco. Rumo a uma outra modernidade. Trad. Sebastião Nascimento. São Paulo: Ed. 34,2010, p. 275. Ver também TZINURIK, Ernesto. O Futuro do Seguro de Responsabilidade Civil. In: JUNIOR, Nelson Nery; NERY, Rosa Maria de Andrade (org.). Doutrinas Essenciais - Responsabilidade Civil: Direito das Obrigações e Direito Negocial. $2^{\mathrm{a}}$ ed. São Paulo: Revista dos Tribunais, 2010. p. 718.

${ }^{2}$ Nesse sentido, conforme ressaltado por Angélica Carlini e Maria da Glória Faria, os riscos estão presentes no cotidiano dos indivíduos, seja o risco de roubo, furto ou colisão de um automóvel, seja o risco de incêndio, roubos ou furtos em residências ou, ainda, o risco de acidentes pessoais. (CARLINI, Angélica; FARIA, Maria da Glória. Fundamentos Jurídicos e Técnicos dos Contratos de Seguro - O dever de proteção da mutualidade, In: MIRAGEM, Bruno; CARLINI, Angélica (Org.). Direitos dos Seguros: Fundamentos de Direito Civil, Direito Empresarial e Direito do Consumidor. São Paulo: Revista dos Tribunais, 2014, pp. 65-66)

${ }^{3}$ Ibidem, pp. 68-69.
} 
Neste cenário, o domínio da teoria das probabilidades, da Lei dos Grandes Números e das ciências atuariais estabeleceu as bases técnicas das operações de seguro e foi determinante para a compreensão do contrato de seguro como operação de prevenção e não mera transferência de riscos, conforme esclarece Vera Helena de Melo Franco ${ }^{4}$.

Seria justamente a sua qualificação como instrumento de prevenção de riscos que distinguiria o seguro de outras operações econômicas, que, embora assemelhadas e consideradas modalidades primitivas de seguros, não podem ser classificadas como tal, uma vez que pressupõem tão somente a transferência do risco a outro participante da relação econômica, ainda que mediante o pagamento de contraprestação previamente ajustada.

Este é o caso, por exemplo, das operações de "seguro marítimo" do final do século XIV. Neste caso, celebrava-se um contrato entre o capitalista ("segurador") e o armador do navio ("segurado"), segundo o qual, em troca do recebimento de uma contraprestação fixa ("prêmio"), caso o navio ou a carga não chegassem em segurança ao porto de destino, o "segurador" estaria obrigado ao pagamento de determinada soma ${ }^{5}$.

Verifica-se, portanto, que, muito embora estas operações marítimas possam ser consideradas uma versão embrionária do contrato de seguro, tal qual previsto atualmente, há uma diferença fundamental em sua estrutura que as afasta da noção de prevenção de risco que fundamenta as operações de seguro.

Isso porque ao transferir ao capitalista o risco de insucesso do empreendimento marítimo, inicialmente suportado pelo armador do navio, faz-se surgir um novo risco: o de insolvência do "segurador", posto que a

\footnotetext{
${ }^{4}$ Nesse sentido, Vera Helena de Melo Franco afirma que "O seguro, com a função que o caracteriza atualmente, somente se tornou possível com o avanço das ciências matemáticas, criando dois novos ramos: a estatística e a atuária. Graças a essas ciências é que se tornou possivel estabelecer as bases técnicas da operação de seguros, afastando a álea de forma a tornar o seguro, efetivamente, uma operação de prevenção de riscos" (FRANCO, Vera Helena de Mello. Operação de seguro e sua qualificação jurídica, In: Revista de Direito Mercantil, Industrial, Econômico e Financeiro. São Paulo. nº 67, jul./set. 1987, p. 40).

${ }^{5}$ Ibidem, p. 40.
} 
obrigação de pagamento de determinado montante será suportada exclusivamente pelo patrimônio pessoal do capitalista ${ }^{6}$.

Resta evidente, portanto, que tal operação importaria apenas uma substituição de riscos, afastando-se o risco do insucesso da campanha marítima, mas agregando em seu lugar o risco de não recebimento da soma pactuada em razão da ausência de recursos do capitalista.

Por esta razão, a origem do contrato de seguro em sua estrutura atual é identificada também no campo dos empreendimentos marítimos, mas em período posterior, com a criação das primeiras companhias náuticas no século XVII ${ }^{7}$.

Neste momento, a aplicação das ciências estatística e atuarial à técnica securitária contribuiu para o desenvolvimento do mecanismo central das operações de seguro, qual seja, a pulverização dos riscos por um grande número de patrimônios submetidos a riscos comuns e homogêneos, que importam cobertura recíproca dos danos eventualmente incorridos.

Nesse sentido, Vera Helena de Melo Franco esclarece que:

"Seguro, economicamente falando, é a cobertura recíproca de uma necessidade fortuita e estimável, relativa às múltiplas economias ameaçadas de igual forma. (...) Somente quando esta reparação [econômica do dano] for obtida, mediante um sistema de compensação entre as diversas economias ameaçadas pelos mesmos riscos é que se terá uma operação de seguro" ${ }^{8}$.

Esclarecida a função do contrato de seguro, antes de passar a análise da estrutura técnico-econômica das operações securitárias, cumpre ressaltar a importância deste instrumento para o avanço do sistema econômico, uma vez que o seu desenvolvimento não somente permitiu que os agentes

\footnotetext{
${ }^{6}$ Ibidem, p. 40.

${ }^{7}$ CARA, Marília de. A aplicabilidade do seguro de responsabilidade civil de administradores e diretores no âmbito da administração das companhias. 142 p. Dissertação de Mestrado, USP, 2013, p. 30. Disponível em http://biblioteca.cvm.gov.br/bnportal/upload/acervo33911/A\%20aplica bilidade $\% 20 \mathrm{do} \% 20$ seguro $\% 20 \mathrm{de} \% 20$ responsabilidade $\% 20$ civil $\% 20 \mathrm{de} \% 20 \mathrm{administradores} \% 20 \mathrm{e} \%$ 20diretores.pdf. Acessado em 21 de outubro de 2017.

${ }^{8}$ Ibidem, p. 42.
} 
econômicos convivessem com o risco, como impulsionou a sua vontade de tomar decisões inovadoras e se expor a situações arriscadas.

Ademais, a própria atividade securitária revela que o domínio do conhecimento matemático, estatístico e atuarial transformou a exposição do risco, originalmente um entrave aos agentes econômicos que buscavam expandir os seus negócios e criar novas oportunidades comerciais, em uma possibilidade de exploração econômica, incorporando-o em proveito próprio.

\subsection{Fundamentos técnicos das operações de seguro}

A partir da transposição da ciência atuarial e da teoria das probabilidades para a técnica securitária, verificou-se que, muito embora o agente que assume a obrigação de suportar os danos decorrentes da concretização do risco, na qualidade de segurador, não seja capaz de antever, para um único contrato, a incidência do sinistro contra o qual o segurado busca se precaver, mediante a observação da incidência de determinado evento em um grande número de casos passados, obtidos a partir de levantamentos estatísticos, é possível indicar, em um dado número de experiências, a probabilidade de ocorrência do sinistro, ao longo de determinado intervalo de tempo e em certa região ${ }^{9}$.

Dito de outro modo, ainda que não seja possível ao segurador prever a incidência do sinistro para cada um dos segurados, a partir da aplicação conjunta dos dados estatísticos e da teoria das probabilidades, ele é capaz de antever a ocorrência deste evento entre um grupo homogêneo de indivíduos submetidos aos mesmos riscos.

Este é justamente o fundamento em que se baseia a Lei dos Grandes Números, segundo a qual "acontecimentos [que] são imprevisíveis para indivíduos se tornam previsíveis entre grupos grandes de indivíduos" 10.

\footnotetext{
${ }^{9}$ GUERREIRO, Marcelo da Fonseca. Seguros Privados: doutrina, legislação e jurisprudência. $2^{\mathrm{a}}$ ed. Rio de Janeiro: Forense Universitária, 2004. pp. 10-11.

${ }^{10}$ CARLINI, Angélica; FARIA, Maria da Glória. Op. Cit., p. 70.
} 
Segundo esta teoria tem-se, ainda, que, quanto maior o conjunto de pessoas submetidas ao risco comum e quanto mais homogêneos forem tais riscos, menor será a diferença entre a probabilidade teórica e aquela verificada empiricamente, isto é, mais próxima da realidade será a previsão de ocorrência de determinado evento ${ }^{11}$.

Deste modo, a técnica securitária pressupõe, para cada tipo de sinistro, a identificação de grupos homogêneos, formados por indivíduos submetidos aos mesmos riscos, e a análise, durante determinado período de tempo, da incidência do sinistro no âmbito destes grupos, de modo que o segurador possa determinar, com razoável grau de certeza, a frequência de incidência do sinistro, bem como a extensão dos danos dele decorrentes, obtendo o montante provável de indenizações, com base no qual será calculado o prêmio puro, o qual, acrescido das despesas operacionais da seguradora, de sua remuneração e despesas com as operações financeiras ${ }^{12}$, corresponderá ao valor a ser pago pelos segurados em contraprestação à garantia prestada pelo segurador ${ }^{13}$.

A contribuição de cada um dos segurados integrantes do mesmo grupo assegura a formação de um fundo comum, que será "administrado" pelo segurador por meio da constituição de provisões técnicas que responderão pelo pagamento das indenizações quando da ocorrência dos sinistros ${ }^{14}$.

É certo, no entanto, que o prêmio pago pelo segurado, que contribuirá para a formação de tais provisões, é muito inferior ao valor que aquele teria

\footnotetext{
${ }^{11}$ RIBEIRO, Amadeu Carvalhaes. Direito de seguros: resseguro, seguro direto e distribuição de serviços. São Paulo: Atlas, 2006, p.73.

${ }^{12}$ Nesse sentido, Ernesto Tzirulnik esclarece a composição do valor do prêmio nos seguintes termos: "Obtido o prêmio puro, são acrescidas as despesas operacionais (comerciais, administrativas, etc.) da empresa de seguros e a remuneração da seguradora, a que se denominam carregamentos. A soma desses elementos constitutivos do prêmio resultado no denominado prêmio comercial. Finalmente, com o acréscimo de adicionais de fracionamento (parcelamento da prestação), despesas com a emissão do documento probatório ou custo de apólice e tributos incidentes (atualmente imposto sobre operação financeira), chega-se ao denominado prêmio bruto." (TZIRULNIK, Ernesto; CAVALCANTI, Flávio de Queiroz B.; PIMENTEL, Ayrton. $O$ Contrato de Seguro de acordo com o novo código civil brasileiro. $3^{\mathrm{a}}$ ed. São Paulo: Editora Roncarati, 2016, p.60, nota de rodapé no ${ }^{\circ}$ ).

${ }^{13}$ FRANCO, Vera Helena de Mello. Op. Cit., p.43.

${ }^{14}$ RIBEIRO, Amadeu Carvalhaes. Op. Cit. p. 83.
} 
que despender caso tivesse de arcar sozinho com as consequências patrimoniais decorrentes do sinistro ${ }^{15}$.

Desse modo, o que garante o equilíbrio entre as receitas oriundas dos prêmios pagos pelos segurados e as despesas incorridas pelo segurador em caso de sinistro é justamente a previsibilidade de que, entre um grupo homogêneo de segurados, somente em alguns casos o risco se concretizará, originando o sinistro e, por conseguinte, a obrigação de pagamento da indenização.

Nota-se, portanto, que o contrato de seguro deve ser operado em massa, uma vez que a sua operacionalização mediante a constituição de um fundo comum e a própria noção de pulverização de riscos (em oposição à ideia de transferência de riscos própria das operações de seguro embrionárias) dependem da contratação simultânea de diversos seguros voltados à garantia de riscos comuns e homogêneos ${ }^{16}$.

Tem-se, então, a base técnico-econômica do contrato de seguro: a mutualidade, a qual, por sua vez, está diretamente ligada à característica de pulverização de riscos própria do contrato de seguro - em sua acepção de instrumento de prevenção de riscos.

Isso porque, tal como exposto inicialmente, o propósito do contrato de seguro é diluir e afastar o risco mediante a distribuição das consequências econômicas do sinistro por um grande número de patrimônios submetidos ao mesmo risco ${ }^{17}$.

Assim, tal como estruturada a operação de seguro, o papel do segurador é viabilizar a formação desta mutualidade, atuando de forma a centralizar as contribuições recebidas de cada um dos segurados e destiná-las para a constituição do fundo comum, nos termos descritos acima. A obrigação da seguradora é garantir que, em caso de ocorrência do sinistro, as provisões

\footnotetext{
${ }^{15}$ FRANCO, Vera Helena de Mello. Op. Cit. p. 43.

${ }^{16}$ Ibidem. p. 64. Vide também: GUERREIRO, Marcelo da Fonseca. Op. Cit. pp. 6-9.

${ }^{17}$ FRANCO, Vera Helena de Mello. Op. Cit., p.43.
} 
técnicas tenham recursos suficientes para fazer frente às suas consequências econômicas mediante o pagamento de compensação econômica ${ }^{18}$.

Dado o caráter organizado e profissional do negócio e o emprego de técnicas e métodos indispensáveis à viabilidade das operações de seguro, é evidente a presença do elemento de empresa na atividade desempenhada pelo segurador.

Desse modo, conclui-se que a análise de um único contrato não é capaz de explicar a racionalidade que está por trás da atividade seguradora, posto que o seguro se estrutura como operação coletiva, dependendo, portanto, da contratação em massa.

Em síntese, a mutualidade poderia ser definida como a pluralidade de sujeitos titulares de interesses legítimos submetidos a riscos comuns e homogêneos, que, a partir da contribuição individual para formação de um fundo comum, assegura a diluição dos riscos a que estão sujeitos entre diversos patrimônios, de modo que nenhum segurado tenha que suportar, isoladamente, os efeitos econômicos da incidência do sinistro, mas que tampouco ocorra a transferência do risco ao segurador ${ }^{19}$. O pagamento das indenizações é garantido, portanto, não por um único patrimônio individual (seja do segurado ou do segurador), mas sim por um patrimônio comum, formado pelo segurador mediante a constituição de provisões técnicas a partir dos prêmios puros pagos pelo segurado.

É fundamental, no entanto, que essa mutualidade seja composta por indivíduos submetidos a riscos de mesma natureza, de modo a assegurar a maior exatidão dos cálculos probabilísticos de ocorrência do sinistro e de

\footnotetext{
${ }^{18}$ TZIRULNIK, Ernesto; CAVALCANTI, Flávio de Queiroz B.; PIMENTEL, Ayrton. Op. Cit. pp. 61-62.

${ }^{19}$ GUERREIRO, Marcelo da Fonseca. Op. Cit. p. 6.
} 
extensão dos danos. Além dos riscos, os interesses objeto dos seguros também devem ser homogêneos ${ }^{20}$.

Isso porque a homogeneidade de riscos e interesses guarda relação direta com a facilidade e a segurança no cálculo do prêmio, uma vez que garantem não apenas que o valor do prêmio seja suficiente para fazer frente às indenizações decorrentes da concretização do sinistro, como também asseguram um tratamento igualitário entre segurados.

Desse modo, indivíduos expostos a riscos semelhantes devem pagar prêmios equivalentes. Por outro lado, também não seria justo que o mesmo prêmio fosse estabelecido para interesses de valores muito dispares, ainda que os riscos aos quais estão submetidos fossem comuns.

Muito embora à primeira vista o agrupamento de riscos e interesses homogêneos aparente ser tarefa fácil, na prática, ele demanda grande esforço por parte do segurador, que se valerá não apenas de uma equipe técnica qualificada para a produção de estatísticas confiáveis, como também da elaboração das condições gerais das apólices de seguro, que serão aplicadas, indistintamente, a todos os segurados de uma mesma carteira ${ }^{21}$.

Conforme será exposto mais detalhadamente quando da análise do prêmio como elemento do contrato de seguro, há, ainda, outras variáveis determinantes para a determinação da contribuição a ser paga por cada um dos segurados integrantes de uma mesma carteira.

Apresentada a estrutura técnica econômica das operações de seguro, passa-se à análise dos aspectos jurídicos do instrumento que formaliza a relação entre segurador e segurado.

\footnotetext{
${ }^{20}$ RIBEIRO, Amadeu Carvalhaes. Op. Cit. p. 75. Vide também: FRANCO, Vera Helena de Mello. Op. Cit. p. 44.

${ }^{21}$ RIBEIRO, Amadeu Carvalhaes, Op. Cit., p. 76.
} 


\subsection{Contrato de seguro}

\subsubsection{Aspectos jurídicos do contrato}

Em se tratando de contrato celebrado em massa, a padronização das cláusulas gerais adquire especial importância, posto que assegura a uniformização do tratamento conferido aos segurados.

Tal homogeneidade é fundamental para assegurar que os riscos objeto de determinada carteira sejam iguais para todos os segurados integrantes daquela mutualidade, uma vez que a padronização das cláusulas gerais delimita expressamente as hipóteses de sinistro englobadas na cobertura securitária e, a contrario sensu, afasta determinadas situações do escopo do seguro. Ademais, com relação a determinadas situações, as cláusulas gerais do contrato de seguro preveem expressamente a sua exclusão ${ }^{22}$.

Desse modo, tal como explica Vera Helena de Mello Franco, "o conteúdo geral de cada contrato não se regula por pactos especiais, variáveis de caso para caso, mas por normas prefixadas, antecipadamente, nas condições gerais das apólices de seguro" ${ }^{23}$. Estas condições gerais são fixadas pela Superintendência de Seguros Privados - SUSEP e representam o conteúdo mínimo obrigatório que deverá constar em todas as apólices de seguro, a variar dependendo da modalidade de seguro contratada.

Esta característica de padronização do contrato de seguro é fundamental para viabilizar a sua contratação em massa e reduzir os custos de transação do segurador, posto que a fase pré-contratual em que são conduzidas as tratativas do contrato, bem como a estipulação de cláusulas individualizadas para cada contratante envolvem custos adicionais ${ }^{24}$.

Por esta razão, o contrato de seguro é classificado como contrato de adesão, o que, em regra, por força do art. 423 da Lei ${ }^{\circ}$ 10.406, de 10 de janeiro de 2002 ("Código Civil”), impõe uma interpretação mais favorável

\footnotetext{
${ }^{22}$ Ibidem, p. 76.

${ }^{23}$ FRANCO, Vera Helena de Mello. Op. Cit., p. 50.

${ }^{24}$ RIBEIRO, Amadeu Carvalhaes. Op. Cit., p. 76.
} 
ao aderente em casos de contradição ou ambiguidade das cláusulas contratuais, sem prejuízo dos casos em que se configure a relação de consumo tutelada especialmente pela Lei $\mathrm{n}^{\mathrm{o}} 8.078$, de 11 de setembro de 1990 (“Código de Defesa do Consumidor”).

Conforme se verá no capítulo 3 deste trabalho, a intervenção estatal na atividade securitária pressupõe não somente a delimitação das condições gerais das apólices de seguro, como diversos outros mecanismos de regulação e supervisão do mercado de seguros, que exercem influência tanto nas condições contratuais quanto na condução da atividade das seguradoras $^{25}$.

Nota-se, portanto, que, não obstante o contrato de seguro ser um contrato típico, expressamente regulado pelas disposições do Código Civil (artigos 757 a 802), sobre ele incidem tanto regras de direito privado quanto normas de direito público. O fenômeno de publicização do seguro decorre justamente dessa atuação do Estado na regulação e fiscalização da atividade securitária $^{26}$.

Ainda no que diz respeito aos caracteres jurídicos do contrato de seguro, cumpre ressaltar a discussão acerca da classificação deste tipo contratual como aleatório ou comutativo.

Conforme definição apresentada por Caio Mário da Silva Pereira,

"São aleatórios os contratos em que a prestação de uma das partes não é precisamente conhecida e suscetível de estimativa prévia, inexistindo equivalência com a da outra parte. Além disto, ficam dependentes de um acontecimento incerto. (...). Basta que haja o risco para um dos contratantes." ${ }^{27}$.

Ademais, da redação do artigo 458 do Código Civil depreende-se que o contrato aleatório seria aquele que diz respeito a coisas ou fatos futuros,

\footnotetext{
${ }^{25}$ MIRAGEM, Bruno. O Direito dos Seguros no Sistema Jurídico Brasileiro: uma introdução. In: MIRAGEM, Bruno; CARLINI, Angélica (Org.). Direitos dos Seguros: Fundamentos de Direito Civil, Direito Empresarial e Direito do Consumidor. São Paulo: Revista dos Tribunais, 2014, pp. 32-36.

${ }^{26}$ Ibidem, p. 26.

${ }^{27}$ PEREIRA, Caio Mário da Silva. Instituições de Direito Civil. Vol. III - Contratos. $17^{\mathrm{a}}$ ed. Rio de Janeiro: Editora Forense, 2013. p. 61.
} 
cujo risco de não virem a existir é assumido por um dos contratantes, assegurada a contraparte a prestação ajustada.

Para alguns autores, não restaria dúvidas quanto à classificação do contrato de seguro como aleatório, posto que a prestação principal do segurador corresponderia ao pagamento da indenização e, por conseguinte, só se verificaria nos casos em que o risco se concretizasse, transformandose em sinistro. Nesse sentido, posicionam-se Caio Mário da Silva Pereira ${ }^{28}$, Marcelo da Fonseca Guerreiro $^{29}$ e Bruno Miragem ${ }^{30}$.

Por outro lado, outros autores, tais como Vera Helena de Mello Franco ${ }^{31}$, Ernesto Tzirulnik, Flávio de Queiroz e Ayrton Pimentel ${ }^{32}$ entendem que esta interpretação se basearia em uma análise do seguro como um contrato isolado e consideraria apenas um único componente da prestação devida pelo segurador.

De forma a defender a comutatividade do contrato de seguro, argumentase que, ao contrário da operação securitária celebrada isoladamente entre um único "segurado" e o "segurador", em que haveria, na realidade, uma transferência do risco de uma parte a outra, assumindo o "segurador" uma espécie de "aposta" quanto à ocorrência do risco e atrelando os seus resultados a este evento, no caso do contrato de seguro organizado como operação de massa e estruturado com base em fundamentos técnicoeconômicos que permitem ao segurador antever a probabilidade de sinistro, a álea decorrente da concretização dos efeitos do sinistro seria suprimida.

Assim, afirma-se que a probabilidade de incidência do sinistro e a extensão dos danos dele decorrentes seria plenamente conhecida pelo

\footnotetext{
${ }^{28}$ Ibidem, p. 61.

${ }^{29}$ Vale ressaltar que Marcelo da Fonseca Guerreiro, além de reconhecer que o caráter aleatório do seguro distinguir-se-ia da aleatoriedade do jogo e da aposta, apresenta justificativa um pouco distinta da apresentada acima para fundamentar o seu posicionamento. Nesse sentido, o autor afirma que o contrato de seguro é um contrato aleatório por não haver equivalência entre as prestações. (GUERREIRO, Marcelo da Fonseca. Op. Cit. pp. 12-13).

${ }^{30}$ MIRAGEM, Bruno. Op. Cit. pp. 41-42.

${ }^{31}$ FRANCO, Vera Helena de Mello. Op. Cit. p. 51.

${ }^{32}$ TZIRULNIK, Ernesto; CAVALCANTI, Flávio de Queiroz B.; PIMENTEL, Ayrton. Op. Cit. pp.45-46.
} 
segurador com base na aplicação das técnicas estatísticas e na teoria da probabilidade, o que não se poderia precisar seria com relação a qual dos integrantes da mutualidade o risco iria se concretizar ${ }^{33}$.

Outro argumento suscitado pela doutrina para afastar a álea do contrato de seguro é que a vantagem almejada pelo segurado com a celebração do contrato não é o recebimento da indenização. Até mesmo porque, para que possa ser celebrado o seguro, o segurado não pode ter interesse na concretização do risco. Na visão de tais autores, haveria, portanto, um equívoco na interpretação conferida à definição de prestação do segurador, a qual, na realidade, consistiria não no pagamento da indenização, mas na garantia conferida ao segurado ao longo de toda a vigência do contrato, conforme reconhecido pelo próprio Código Civil em seu artigo 757, caput $^{34}$.

Ao celebrar um contrato de seguro, o segurado não buscaria propriamente o recebimento de indenização a ser paga pelo segurador ou, muito menos, o afastamento da ocorrência do sinistro. Na realidade, o segurador celebraria o contrato de seguro e pagaria o prêmio ajustado objetivando obter em contrapartida a segurança e a tranquilidade de que, caso viesse a ocorrer o evento futuro e incerto caracterizado como sinistro, as consequências patrimoniais negativas seriam suportadas pela seguradora.

No entanto, tal posicionamento sofre algumas críticas da corrente doutrinária que defende o caráter aleatório do contrato de seguro. Isso porque, de acordo com o exposto por Bruno Miragem, "a técnica empresarial de dispersão da álea pelo segurador não modifica a natureza do contrato. (...). Note-se, pois, que a álea não se confunde com a causa do contrato, constitui na verdade parte do seu objeto." 35.

\footnotetext{
${ }^{33}$ Ibidem, p. 46.

${ }^{34}$ Ibidem, p. 45.

${ }^{35}$ MIRAGEM, Bruno. Op. Cit. p. 42.
} 


\subsubsection{Elementos do contrato}

Tradicionalmente, Fábio Konder Comparato, autor do substitutivo ao capítulo do Código Civil referente ao seguro, identifica quatro elementos fundamentais do contrato de seguro, quais sejam, (i) o interesse; (ii) o risco; (iii) o prêmio; e (iv) a garantia ${ }^{36}$.

A partir da redação do artigo 757 do Código Civil, segundo a qual "[p]elo contrato de seguro, o segurador se obriga, mediante o pagamento do prêmio, a garantir interesse legítimo do segurado, relativo a pessoa ou a coisa, contra riscos predeterminados"(g.n.), vislumbram-se os referidos elementos indicados por Comparato.

É possível encontrar ainda referências a outros elementos, tal como defendem Ernesto Tzirulnik, Flávio Cavalcanti e Ayrton Pimentel ${ }^{37}$, que enxergam na empresarialidade um quinto elemento do contrato de seguro.

No entanto, este quinto elemento se confunde em certa medida com a própria estrutura econômica e técnica que serve de base para o contrato de seguro, razão pela qual, ao longo do presente trabalho, serão analisados os quatro elementos tradicionais do contrato de seguro.

\subsubsection{Interesse Legítimo}

Antes de adentrar o conceito de interesse legítimo, conforme previsto no Código Civil, cumpre ressaltar a divergência doutrinária existente com relação à definição do objeto do contrato de seguro.

Quanto a este tema, Fábio Konder Comparato esclarece que, enquanto o objeto do contrato de seguro é sempre um interesse submetido a risco, a sua

\footnotetext{
${ }^{36}$ COMPARATO, Fábio Konder. Notas explicativas ao substitutivo ao capítulo referente ao contrato de seguro no anteprojeto de Código Civil. Revista de Direito Mercantil, vol. 5, p.147. São Paulo: Ed. RT, 1972.

${ }^{37}$ TZIRULNIK, Ernesto; CAVALCANTI, Flávio de Queiroz B.; PIMENTEL, Ayrton. Op. Cit. p. 43.
} 
causa, isto é, a motivação que justificaria a celebração do contrato de seguro, seria a assunção deste risco pela companhia seguradora ${ }^{38}$.

Por sua vez, Ernesto Tzirulnik, Flávio Cavalcanti e Ayrton Pimentel apresentam uma diferenciação entre objeto mediato e imediato do contrato de seguro, argumentando que a garantia seria o objeto imediato do seguro e o interesse o objeto da garantia, por conseguinte, objeto mediato do contrato $^{39}$.

Há ainda quem defenda, em uma visão mais tradicional, que o objeto do contrato de seguro seria o risco ${ }^{40}$.

Diante desta controvérsia doutrinária, o Ministro aposentado do Superior Tribunal de Justiça - STJ, Ruy Rosado, em palestra no Congresso Internacional sobre Direito do Seguro ${ }^{41}$, esclareceu que, a partir do texto legal, tem-se que, do ponto de vista jurídico, o objeto imediato de todo contrato é a regulação de uma relação obrigacional, o que não seria diferente no contrato de seguro, que visaria regular a relação entre segurador e segurado. Por sua vez, o objeto mediato do ponto de vista jurídico (e imediato do ponto de vista material) seria o interesse do segurado relativamente ao bem ou pessoa que esteja exposto ao risco.

Isto posto, passa-se a analisar propriamente o conceito de interesse.

Em linhas gerais, o interesse como elemento do contrato de seguro pode ser definido como a relação economicamente apreciável e juridicamente relevante entre o bem ou pessoa submetido ao risco ${ }^{42}$.

\footnotetext{
${ }^{38}$ Segundo Fábio Konder Comparato conforme citado por TZIRULNIK, Ernesto; CAVALCANTI, Flávio de Queiroz B.; PIMENTEL, Op. Cit. pp. 44-45.

${ }^{39}$ Ibidem, pp. 44-45.

${ }^{40}$ PEREIRA, Caio Mário da Silva Pereira. Op. Cit. p. 419.

${ }^{41}$ Exposição do Ministro aposentado Ruy Rosado no Painel "A teoria do interesse e o dano físico nos seguros de dano" realizada em 21 de maio de 2014 no âmbito do Congresso Internacional sobre Direito do Seguro, promovido pelo Conselho da Justiça Federal (CFJ). Disponível em https://www.youtube.com/watch?v=YvDihBKPBIg. Vídeo reproduzido em 07 de outubro de 2017.

${ }^{42}$ TZIRULNIK, Ernesto; CAVALCANTI, Flávio de Queiroz B.; PIMENTEL, Ayrton. Op. Cit. p. 48 e RIBEIRO, Amadeu Carvalhaes. Op. Cit. p. 60.
} 
Nota-se, portanto, que o objeto de proteção do contrato de seguro não é propriamente o bem ou a pessoa em si, mas sim o interesse do segurado com relação a eles. Justamente por ser o interesse o objeto da proteção do seguro que é possível conceber o pagamento de indenização em caso de incidência do sinistro em seguro de vida ${ }^{43}$.

Evidencia-se, ainda, que deve ser possível apreciar economicamente o interesse segurável, de modo que o segurador possa prever, em média, a extensão das indenizações a serem pagas aos segurados e, por conseguinte, fixar o valor do prêmio com base nesses parâmetros.

Ademais, ao referir-se a "interesse legítimo", o legislador buscou não somente afastar a possibilidade de contratação de seguro para cobertura de riscos ilícitos, mas, principalmente, assegurar que o segurado contratante tenha interesse em prevenir a incidência do sinistro. Busca-se evitar que o contrato de seguro seja utilizado como instrumento especulativo por aqueles que não têm interesse legítimo na preservação do bem ou da pessoa ${ }^{44}$.

De outro modo, o sinistro deixaria de ser um evento negativo na esfera patrimonial do segurado, passando a representar a concretização de um investimento, uma vez que, mediante o pagamento de prêmio de valor relativamente baixo, o segurado faria jus ao recebimento de indenização em montante expressivamente superior, lucrando, portanto, com a verificação do sinistro predeterminado.

Além disso, não seria irrazoável imaginar que determinados segurados não legitimados se sentissem estimulados a contribuir para a ocorrência do sinistro.

Em se tratando de seguro de dano, a aplicação do princípio indenitário tem por objetivo esclarecer igualmente que o contrato de seguro busca a

\footnotetext{
${ }^{43}$ Nesse sentido, Amadeu Carvalhaes Ribeiro afirma que: "[é] precisamente porque há um interesse economicamente apreciável para o beneficiário na vida do segurado que é possível estabelecer a importância segurada" (RIBEIRO, Carvalhaes Amadeu. Op. Cit. p. 60).

${ }^{44}$ Ibidem, pp. 60-61.
} 
compensação dos prejuízos sofridos em razão da ocorrência do sinistro, não podendo ser utilizado como meio de enriquecimento do segurado. Para tanto, limita-se a indenização a ser recebida pelo segurado ao montante correspondente aos prejuízos sofridos, não sendo possível estabelecer um valor superior ${ }^{45}$.

Caso contrário, o contrato de seguro perderia a sua natureza de instrumento de preservação de risco e a sua finalidade de recomposição dos efeitos patrimoniais negativos advindos do sinistro.

\subsubsection{Garantia}

Seja como objeto imediato do contrato de seguro (Tzirulnik, Cavalcanti e Pimentel), seja como causa de sua contratação (Comparato) é certo que na sistemática do Código Civil de 2002 a garantia ocupa papel de destaque na caracterização do contrato de seguro.

Com a evolução dos estudos sobre as operações de seguro, notadamente os seus aspectos técnico-econômicos, questiona-se a concepção da indenização como dever único do segurador, cujo cumprimento se diferiria no tempo e estaria condicionado à ocorrência do sinistro.

Nesse sentido, Amadeu Carvalhaes Ribeiro esclarece que:

"[n]inguém contrata um seguro com a finalidade imediata de obter uma indenização. O segurado não quer ser indenizado, quer apenas a garantia de que um eventual sinistro não prejudicará sua atividade econômica elou sua situação financeira. E essa garantia quem lhe dá é o segurador",46.

A partir desta concepção, a prestação principal devida pelo segurador seria a garantia de que, em caso de concretização do evento predeterminado como sinistro, os seus efeitos não repercutirão negativamente no patrimônio do seguro.

\footnotetext{
${ }^{45}$ ALVIM, Pedro. O seguro e o novo código civil (Organização e compilação de Elizabeth Alvim Bonfioli). Rio de Janeiro: Forense, 2007, pp. 95-96.

${ }^{46}$ RIBEIRO, Amadeu Carvalhaes. Op. Cit. p. 63.
} 
Cumpre ressaltar os esclarecimentos prestados por Pontes de Miranda quanto à prestação devida pelo segurador.

Nesse sentido, o jurista explica que a contraprestação ao pagamento do prêmio seria propriamente a obrigação assumida pelo segurador de prestar uma garantia, a qual se apresenta de dois modos: ao longo de toda a vigência do contrato de seguro, esta garantia representa a proteção conferida ao interesse legítimo do segurado, e, com a ocorrência do sinistro, a garantia pressupõe o pagamento da indenização. Dito de outro modo, a prestação do segurador seria única, contudo, ela importaria em comportamentos distintos a depender do momento contratual ${ }^{47}$.

\subsubsection{Risco}

Observadas as considerações apresentadas até o momento no presente trabalho, não restam dúvidas de que o risco é elemento essencial do contrato de seguro, sem o qual, inclusive, não há que se falar em seguro.

A importância do risco está evidenciada na previsão do artigo 773 do Código Civil, segundo a qual, "[o] segurador que, ao tempo do contrato, sabe estar passado o risco de que o segurado se pretende cobrir, e, não obstante, expede a apólice, pagará em dobro o prêmio estipulado". Isso porque entende-se que, neste caso, não estando exposto a risco o interesse legítimo, não há objeto a ser segurado, configurando, portanto, enriquecimento sem causa por parte do segurador. Para que o interesse legítimo possa ser segurável, ele deverá estar submetido a um risco possível.

Em linhas gerais, o risco pode ser definido como a probabilidade de ocorrência de evento pré-determinado passível de causar consequências economicamente adversas ao segurado. O sinistro, por sua vez, seria a concretização do risco.

\footnotetext{
${ }^{47}$ Conforme apontamentos suscitados pelo Ministro Ruy Rosado em sua explanação no Congresso sobre Direito do Seguro, conforme nota de rodapé $n^{\circ} 41$.
} 
Muito embora se afirme que o risco diz respeito a evento futuro e incerto, se o considerarmos em sua dimensão coletiva, isto é, como risco ao qual estão submetidos todos os segurados integrantes de uma mesma mutualidade, é possível verificar que a sua regularidade e a intensidade de sua incidência podem ser antecipados a partir da aplicação da técnica securitária ${ }^{48}$.

Deste modo, como muito bem esclarecido por Tzirulnik, Cavalcanti e Pimentel, o conceito de risco não deve ser confundido com a incerteza individual quanto à incidência de determinado evento ${ }^{49}$.

Conforme exposto inicialmente, a previsibilidade do risco é fundamental para que o segurador possa agrupar os segurados sujeitos a riscos comuns e homogêneos, bem como para que possa precificar adequadamente a contribuição a ser paga por cada segurado, mantendo uma proporcionalidade entre prêmio puro e montante correspondente às indenizações a serem suportadas pelo segurador.

Por esta razão, o agravamento do risco altera substancialmente as bases sobre as quais foram estabelecidas as condições do contrato de seguro, podendo comprometer o equilibro entre despesas e prêmios, rigorosamente estabelecido pelo segurador ${ }^{50}$.

A sistemática do Código Civil prevê, portanto, que uma quebra na proporcionalidade entre prêmio e risco pode acarretar a revisão ou mesmo a extinção do contrato, nos seguintes termos.

“Art. 768. O segurado perderá o direito à garantia se agravar intencionalmente o risco objeto do contrato.

Art. 769. O segurado é obrigado a comunicar ao segurador, logo que saiba, todo incidente suscetivel de agravar consideravelmente o risco coberto, sob pena de perder o direito à garantia, se provar que silenciou de má-fé.

\footnotetext{
${ }^{48}$ TZIRULNIK, Ernesto; CAVALCANTI, Flávio de Queiroz B.; PIMENTEL, Ayrton. Op. Cit. p. 58 .

${ }^{49}$ Ibidem, p. 58 .

${ }^{50}$ Ibidem, p. 59.
} 
$\$ 1^{\circ} O$ segurador, desde que o faça nos quinze dias seguintes ao recebimento do aviso da agravação do risco sem culpa do segurado, poderá dar-lhe ciência, por escrito, de sua decisão de resolver o contrato".

Da redação destes dispositivos depreende-se que diante de um agravamento do risco não intencional, caberá ao segurado comunicar imediatamente tal fato ao segurador, o qual poderá, dentro de 15 dias da comunicação, decidir se resolverá o contrato de seguro ou exigirá a complementação do prêmio. Caso o segurado agrave intencionalmente o risco ou silencie sobre tal fato de má-fé, perderá o direito à garantia ${ }^{51}$.

Da mesma forma, caso haja uma redução considerável no risco coberto, o segurado poderá exigir a revisão do prêmio ou, ainda, a resolução do contrato, conforme se verifica da redação do artigo 770 do Código Civil, segundo a qual:

"Art. 770. Salvo disposição em contrário, a diminuição do risco no curso do contrato não acarreta a redução do prêmio estipulado; mas, se a redução do risco for considerável, o segurado poderá exigir a revisão do prêmio, ou a resolução do contrato."

Por se tratar de contrato de adesão, cujas regras de hermenêutica determinam que seja interpretado em favor do aderente em caso de contradição ou omissão, sem prejuízo de eventuais normas consumeristas aplicáveis em caso de configuração de relação de consumo, é igualmente importante que os riscos cobertos pelo seguro e os riscos excluídos estejam claramente descritos na apólice, de modo a assegurar que a seguradora considere todos os eventos abarcados pelo contrato no cálculo do prêmio.

Em se tratando de riscos excluídos, a redação do Código Civil de 2002, aprimorada a partir da redação original do Código Civil de 1916, proíbe a cobertura de risco proveniente de ato doloso do segurado ou do beneficiário do seguro, nos termos do artigo 762 do Código Civil ${ }^{52}$. A contrario sensu, é possível, no entanto, a cobertura de atos ilícitos culposos, os quais eram

\footnotetext{
${ }^{51}$ GOLDBERG, Ilan . Confiança, cooperação, máxima boa-fé e o contrato de seguro. Rio de Janeiro: Revista Jurídica de Seguros, 2017.

${ }^{52}$ Art. 762 . Nulo será o contrato para garantia de risco proveniente de ato doloso do segurado, do beneficiário, ou de representante de um ou de outro.
} 
afastados sob o regime do Código Civil de 1916, em razão da redação do artigo $1.436^{53}$, que se referia genericamente a "atos ilícitos", e que correspondem justamente à cobertura dos seguros de responsabilidade civil.

\subsubsection{Prêmio}

O último elemento do contrato de seguro a ser analisado é o prêmio, que corresponde à contribuição devida por cada um dos segurados em contraprestação à garantia prestada pelo segurador ao longo da vigência do contrato de seguro.

Ainda que, ao contrário de outros elementos, o prêmio não suscite grandes controvérsias doutrinárias quanto à sua natureza ou ao papel desempenhado no contrato de seguro, tal elemento é de igual importância no desenvolvimento das operações securitárias. Isso porque a capacidade da seguradora de fazer frente às indenizações dependerá, em larga medida, da adequada precificação dos prêmios cobrados dos segurados.

Nesse sentido, tal como adiantado no item 1.2 deste capítulo, há uma relação de equivalência direta entre os prêmios puros e o montante das indenizações que, eventualmente, serão devidas pelo segurador quando da concretização do risco, estipulado com base nos cálculos de probabilidade de ocorrência do sinistro e na aferição da extensão dos seus danos ${ }^{54}$.

Por esta razão, o prêmio puro é utilizado como parâmetro para verificar a higidez da seguradora, e, por conseguinte, evitar que, diante de um desequilíbrio de suas contas, esta última coloque em risco o pagamento das indenizações ajustadas ou o tratamento igualitário dos segurados mediante a elevação dos prêmios para segurados submetidos a risco comum ${ }^{55}$.

Por outro lado, esta relação de equivalência procura evitar abusos por parte do segurador, que, objetivando eliminar seus concorrentes, pode

\footnotetext{
${ }^{53}$ Art. 1.436. Nulo será este contrato, quando o resto, de que se ocupa, se filiar a atos ilícitos do segurado, do beneficiado pelo seguro, ou dos representantes e propostos, quer de um, quer do outro.

${ }_{55}^{54}$ RIBEIRO, Amadeu Carvalhaes. Op. Cit. p. 79.

55 Ibidem, p. 80.
} 
praticar prêmios muito abaixo do montante necessário para arcar com o volume de sinistros, colocando em risco o conjunto de segurados ou elevando a sua dependência de seus resultados financeiros.

Demonstrada a importância da equivalência entre indenizações e prêmios puros, compete ao segurador segregar os valores oriundos dos prêmios puros do restante de seu patrimônio, sob a forma de provisões técnicas, de modo a assegurar a existência de recursos suficientes ao pagamento das indenizações enquanto perdurar a garantia prestada pelo segurador ${ }^{56}$.

Ao longo do tempo, conforme os riscos forem se concretizando, as provisões serão consumidas para o pagamento das indenizações. Somente ao final da vigência do contrato de seguro, as provisões remanescentes poderão ser incorporadas em definitivo no patrimônio do segurador ${ }^{57}$.

Percebe-se, portanto, que esta relação de equivalência entre indenizações e prêmios puros é a base da técnica securitária.

\subsubsection{Aplicação da máxima boa-fé no contrato de seguro}

É certo que o regime legal dos contratos no Código Civil de 2002 prevê a boa-fé como cláusula geral, aplicável não somente na interpretação dos contratos, como também no momento de sua celebração e execução.

Nada obstante se tratar de norma aplicável a todas as espécies contratuais, o legislador achou por bem ressaltar a boa fé no contrato de seguro, prevendo no artigo 765 do Código Civil que "[o] segurado $e$ o segurador são obrigados a guardar na conclusão e na execução do contrato, a mais estrita boa-fé e veracidade, tanto a respeito do objeto como das circunstâncias e declarações a ele concernentes" (g.n). Por esta razão, fala-se em "máxima boa fé" no contrato de seguro ${ }^{58}$.

\footnotetext{
${ }^{56}$ Ibidem, p. 83.

${ }^{57}$ Ibidem, pp. 85-86.

${ }^{58}$ ALVIM, Pedro. Op. Cit. p. 44. Vide também: MIRAGEM, Bruno. Op. Cit. pp. 30-31.
} 
Em primeiro lugar, destaca-se que a aplicação da boa fé no contrato de seguro adquire um forte viés informacional, tanto no momento da formação do contrato quanto ao longo de sua execução. Isso porque o segurador depende das informações prestadas pelo potencial contratante (segurado) quanto ao seu perfil ou às atividades profissionais por ele desempenhadas para avaliar os riscos que envolvem o interesse legítimo a ser garantido. Esta avaliação é que norteará a decisão do segurador de subscrever ou não estes riscos e delimitará o cálculo do prêmio a ser cobrado ${ }^{59}$.

Para que o seguro possa desempenhar a sua finalidade de operação de massa, atendendo a conjunto amplo de indivíduos submetidos a riscos homogêneos, é certo que a sua operacionalização não pode depender de burocráticos processos de fiscalização e pesquisas aprofundadas conduzidas junto aos segurados ${ }^{60}$.

Neste cenário, as informações prestadas pelos contraentes são essenciais para a decisão do segurador de contratar ou não a garantia daquele risco, razão pela qual exigem a mais estrita honestidade e lealdade por parte do segurado, que não poderá manipular ou omitir dados relevantes.

No que diz respeito ao seguro de responsabilidade civil de administradores, no entanto, esta fase pré-contratual de avaliação de riscos é mais complexa, uma vez que, por se tratar de seguro contratado, na maioria das vezes, pela própria sociedade, conforme explicitado no capítulo 3 abaixo, envolve não somente a análise do perfil do beneficiário do seguro, como também o exame da própria empresa ${ }^{61}$.

Desta avaliação dependerá a elegibilidade da companhia, isto é, a decisão da seguradora de celebrar ou não contrato de seguro com esta sociedade, o

\footnotetext{
${ }^{59}$ MIRAGEM, Bruno. Op. Cit. p. 45. Vide também: FRANCO, Vera Helena de Mello. Op. Cit. p. 51. e GUERREIRO, Marcelo da Fonseca. Op. Cit. p. 30.

${ }^{60}$ GOLDBERG. Ilan. Op. Cit. pp. 10-16.

${ }^{61}$ MAIA, Roberta Mauro Medina; BURMAN, Leonardo Joseph. Apontamentos sobre o seguro de responsabilidade civil para atos de gestão de administradores ou diretores de empresas (D\&O). In: Revista Trimestral de Direito Civil. Rio de Janeiro. Vol. 30, abr./jun. 2007, p.135.
} 
que, como veremos adiante, estimula, inclusive, as companhias a desenvolverem boas práticas de governança corporativa.

Portanto, nos termos expostos por Roberta Mauro Medina e Leonardo Burman,

"não se pode dizer que os riscos são homogêneos, variando de acordo com o tipo de atividade desempenhada pela empresa, o histórico profissional de seus diretores e administradores, a existência ou não de holdings, a figura societária escolhida, dentre outros fatores" ${ }^{62}$.

Ainda assim, isto não significa que não se exija a observância da mais estrita boa fé na prestação das informações solicitadas pela seguradora com relação a esta espécie de seguro. Além disso, o que se verifica do regime previsto no Código Civil é que o comportamento de boa fé deverá perdurar ao longo de toda a vigência do seguro, cabendo ao segurado comunicar à seguradora qualquer incidente suscetível de agravar consideravelmente o risco coberto.

Não basta, portanto, assegurar a correta avaliação do risco no momento da celebração do seguro, visto que, o agravamento do risco coberto alterará as bases sobre as quais foram firmadas o contrato de seguro, podendo exigir um reajuste no prêmio cobrado ou, até mesmo, modificar a decisão do segurador de suportar o risco, conforme exposto anteriormente.

No caso de prestação de declarações inexatas ou omissão de informações pelo segurado, que possam influir na aceitação da proposta pelo segurador ou no valor do prêmio fixado, sendo verificada a má-fé do segurado, este perderá o direito à garantia, mas continuará obrigado pelo prêmio ${ }^{63}$.

Por outro lado, no caso em que a inexatidão ou omissão nas declarações não resulte de má-fé do segurado, o parágrafo único, do artigo 766 do

\footnotetext{
${ }^{62}$ Ibidem, p.135.

${ }^{63}$ Art. 766. Se o segurado, por si ou por seu representante, fizer declarações inexatas ou omitir circunstâncias que possam influir na aceitação da proposta ou na taxa do prêmio, perderá o direito à garantia, além de ficar obrigado ao prêmio vencido.

Parágrafo único. Se a inexatidão ou omissão nas declarações não resultar de má-fé do segurado, o segurador terá direito a resolver o contrato, ou a cobrar, mesmo após o sinistro, a diferença do prêmio.
} 
Código Civil determina que terá direito o segurador de resolver o contrato, ou a cobrar, mesmo após o sinistro, a diferença do prêmio. A princípio, dáse a entender que a opção pela resolução ou pela cobrança adicional do prêmio competirá ao segurador.

Defende-se, no entanto, que, em observância ao princípio da preservação do contrato, este último só poderá ser desfeito pelo segurador quando este demonstrar que as alterações no risco por ele avaliado inicialmente foram tais que modificariam a sua decisão de celebrar o contrato, não sendo suficiente a cobrança de prêmio adicional ${ }^{64}$.

Nesse sentido, vem decidindo os Tribunais de Justiça, em especial nos casos em que se verifica que o segurado tinha conhecimento da existência de investigações ou, até mesmo, reclamações envolvendo possíveis fatos geradores do sinistro coberto pelo seguro $\mathrm{D} \& \mathrm{O}$, conforme se vê da ementa a seguir (g.n.):

Cobrança - Indenização securitária - Apólice de Seguro de Responsabilidade Civil Geral de Administradores - Recusa da seguradora estribada em omissão de informações relevantes, pelo segurado, quando do preenchimento do questionário dele exigido no momento da contratação - Recusa também amparada em decorrência da exclusão da cobertura causada por agravamento intencional do risco - Hipóteses excludentes devidamente demonstradas pela seguradora - Danos morais ao segurado que igualmente não são devidos - Sentença de improcedência mantida, ainda que por fundamento diverso - Recurso não provido. (Apelação Cível $\mathrm{n}^{\circ}$ 017225084.2010+8.26.0100, $10^{\mathrm{a}}$ Câmara de Direito Privado, TJSP, Des. Rel. Roberto Maia, julg. em 25.06.2013).

Convém ressaltar, ainda, o seguinte trecho da sentença recorrida na Apelação Cível no 1095579-95.2013.8.26.0100, cuja ementa foi transcrita acima:

"Neste particular vale ressaltar que ainda que tais questionamentos não tenham sido diretamente feitos pela ré, não poderiam os segurados ter omitido informações de substancial relevância para a definição das bases objetivas do negócio jurídico. É sabido e consabido que o contrato de seguro é permeado pela mais estrita boa-fé, seja em sua faceta objetiva (conduta) seja na subjetiva (conhecimento), ex vi do disposto no artigo 765 do Código Civil" (43 ${ }^{\mathrm{a}}$ Vara Cível do Foro Central da Comarca de São Paulo, Juiz Miguel Ferrari Júnior).

\footnotetext{
${ }^{64}$ GOLDBERG, Ilan. Op. Cit. pp. 17-18. Vide também: ALVIM, Pedro. Op. Cit., p. 50.
} 
Muito embora o enfoque da boa fé no contrato de seguro recaia, em grande parte, sobre o segurado, tal comportamento é exigido igualmente do segurador, seja no momento de elaboração das cláusulas contratuais e na definição dos riscos cobertos, seja no compromisso de não celebrar contrato de seguro caso tenha ciência da inexistência do risco.

No caso do segurador, a observância da máxima boa fé é ainda mais importante no campo das regulações e liquidações de sinistro, posto que, neste momento, o segurado encontra-se em estado de necessidade por ter sido atingido pelos efeitos patrimoniais da ocorrência do sinistro, dependendo de uma rápida definição da seguradora quanto ao pagamento da indenização.

No entanto, o que se verifica na prática é que este é o momento propício para comportamentos oportunistas por parte da seguradora, que, mesmo ciente da importância para o segurado da rápida apuração dos danos e solvência da indenização, atua de forma contrária à boa fé, recusando o pagamento da indenização acordada, sob a justificativa de inaplicabilidade da garantia, ou mesmo o condicionando a procedimentos dilatórios na fase de regulação e liquidação, com o propósito de convencer o segurado a celebrar acordo por valor significativamente inferior à indenização devida ${ }^{65}$.

65 TZIRULNIK, Ernesto; CAVALCANTI, Flávio de Queiroz B.; PIMENTEL, Ayrton. Op. Cit. pp. 112-113. 


\section{CAPÍTULO 2 - O REGIME LEGAL DE RESPONSABILIDADE DOS ADMINISTRADORES}

Antes de examinar os elementos do seguro de responsabilidade civil de administradores e a regulamentação desenvolvida pela SUSEP, faz-se necessário tecer algumas considerações gerais quanto ao risco do qual procura resguardar-se o administrador mediante a contratação do seguro $\mathrm{D} \& \mathrm{O}$, qual seja, os efeitos patrimoniais negativos advindos de eventual responsabilização do administrador por atos praticados no exercício de suas funções na administração da companhia.

Nesse sentido, é forçoso reconhecer os altíssimos riscos em que estão envolvidas as funções desempenhadas pelos administradores na gestão de companhias.

Isso porque, além de o processo de tomada de decisões no âmbito empresarial envolver alto grau de incerteza, visto que exige do administrador a ponderação de alternativas de ação diante de determinada situação concreta, e, usualmente, em um curto período de tempo, igualmente incertas são as consequências decorrentes de tais ações. Em determinadas situações, as decisões negociais tomadas no âmbito da companhia produzem efeitos para além da esfera social, acarretando prejuízos a terceiros.

Diante deste cenário, pondera-se entre, de um lado, a tutela de interesses particulares e/ou coletivos lesados em razão da atividade empresarial, e, de outro, a necessidade de resguardar, em certa medida, os administradores dos efeitos decorrentes das decisões negociais, tomadas no curso do exercício regular da gestão social, de modo a não afastar os profissionais capacitados da administração das companhias e inviabilizar a atividade empresarial.

Dada a amplitude do tema e a finalidade a que se propõe o presente trabalho, conforme delimitada na seção introdutória, a análise do regime legal de responsabilidade dos administradores desenvolvida neste capítulo 
se limitará a abordar os aspectos essenciais à adequada compreensão do seguro $\mathrm{D} \& \mathrm{O}$ e à delimitação da cobertura prevista nesta modalidade de seguro.

Conforme ressaltado na introdução a este trabalho, o objetivo deste segundo capítulo é delimitar os riscos aos quais estão expostos os administradores e que, eventualmente, poderão ser objeto de garantia pelo seguro D\&O ou que estarão excluídos da cobertura securitária.

\subsection{As esferas de responsabilização do administrador}

Em razão da complexidade das relações que envolvem a administração de companhias abertas, a responsabilidade dos administradores por atos de gestão se estende por diversas esferas do direito, podendo incidir sobre tais atos normas de natureza cível, administrativa, criminal, tributária, ambiental, trabalhista, previdenciária, consumerista, concorrencial e falimentar.

A depender do ramo do direito, ampliam-se as situações em que o administrador pode vir a responder pessoalmente por determinado ato praticado na gestão da companhia, em grande medida em razão de interpretações jurisprudenciais, tal como se verifica na esfera trabalhista e consumerista, inclusive, por meio da adoção de interpretação ampliativa acerca da teoria da desconsideração da personalidade jurídica ${ }^{66}$.

No entanto, tal como será exposto mais detalhadamente adiante, em regra, os regimes de responsabilização observam o princípio geral segundo

\footnotetext{
${ }^{66}$ Com relação à esfera trabalhista, Clara Beatriz Lourenço de Faria esclarece que "[i]ndependentemente da fundamentação legal adotada, a tendência dos tribunais brasileiros tem sido a atribuição de responsabilidade aos administradores de forma subsidiária, atingindo os seus bens nas hipóteses de desconsideração da personalidade jurídica, ante a inexistência de bens da sociedade suficientes para saldar a dívida, e independente da comprovação de má administração" (p. 49). Por sua vez, no que diz respeito à esfera consumerista, a autora afirma que "o julgado revela a exposição a que estão sujeitos os administradores das sociedades no que tange à responsabilidade civil no âmbito do consumidor, que permite a desconsideração da personalidade jurídica ainda que não haja atuação fraudulenta do administrador, e pode alcançar não só os diretores, como os membros do conselho de administração" (p. 65) (FARIA, Clara Beatriz Lourenço de. Op. Cit. p. 49 e 65).
} 
o qual a responsabilidade pessoal do administrador depende da demonstração do elemento subjetivo.

Não obstante a multiplicidade de normas jurídicas aplicáveis aos administradores de companhias abertas, há três planos de destaque em que são projetadas as responsabilidades dos administradores: civil, administrativo e penal, os quais passam a ser analisados na sequência.

\subsubsection{Responsabilidade Civil}

De um modo geral, a disciplina da responsabilidade civil desempenha um papel fundamental na manutenção do equilíbrio das relações privadas, modificado a partir do evento danoso decorrente da conduta de determinado agente $^{67}$. A responsabilidade civil assegura, portanto, a recomposição da esfera econômico-jurídica do sujeito lesado, buscando sempre o retorno ao estado anterior ao dano ${ }^{68}$.

Há ainda quem identifique uma segunda função desempenhada pela responsabilidade civil, qual seja, a prevenção de práticas ilegais por meio do estímulo ao enquadramento da conduta do administrador aos deveres a ele impostos no plano societário.

Nesse sentido, Nelson Eizirik argumenta que o sistema de responsabilidade civil representaria um meio de controle da atuação dos administradores ${ }^{69}$, assegurando um equilíbrio entre os poderes conferidos a estes profissionais e os deveres a que estão submetidos por força da legislação societária e das disposições do estatuto social, conforme será exposto detalhadamente no item 2.1.1.1 a seguir.

\footnotetext{
${ }^{67}$ EIZIRIK, Nelson. Responsabilidade Civil e Administrativa do Diretor de Companhia Aberta. In: Revista de Direito Mercantil, Industrial, Econômico e Financeiro, São Paulo, n 56, out./dez. 1984, p. 49.

${ }^{68}$ José de Aguiar Dias esclarece que "o interesse em reestabelecer o equilíbrio econômico-jurídico alterado pelo dano é a causa da responsabilidade civil" (DIAS, José Aguiar. Da responsabilidade civil. Rio de Janeiro: Editora Lumen Iuris, 2012, p. 43).

${ }^{69}$ EIZIRIK, Nelson. Op. Cit. p. 49. No mesmo sentido, Marcelo Vieira Von Adamek afirma que "a responsabilidade civil, escusado dizê-lo, constitui importante elemento de regulação da conduta dos administradores, pois torna efetivos os seus vários deveres nos planos societários (...)" (ADAMEK, Marcelo Vieira Von. Responsabilidade civil dos administradores de S/A (e as ações correlatas). São Paulo: Saraiva, 2009. p. 113).
} 
Ao impor a responsabilização pessoal do administrador em determinadas hipóteses, o legislador tem por objetivo impedir desvios de conduta, em que o administrador utilize os poderes a ele atribuídos em proveito próprio ou de forma negligente.

Como veremos adiante neste trabalho, esta função preventiva do regime de responsabilidade civil está profundamente ligada à preocupação demonstrada por alguns autores de que o seguro D\&O favoreça uma conduta negligente ou, até mesmo, oportunista do administrador, identificada como o risco moral do seguro (moral hazard).

\subsubsection{A responsabilidade civil dos administradores na Lei das}

\section{S.A.}

Como exposto na introdução a este capítulo, por exercerem parcela significativa do poder social, notadamente nesta nova etapa de aprofundamento do fenômeno de dissociação entre a propriedade e o controle $^{70}$, a atuação dos administradores na gestão social pode ocasionar danos significativos à própria companhia, aos acionistas ou a terceiros.

Por esta razão, de forma a balancear os poderes atribuídos pela lei e pelos estatutos aos administradores (responsabilidade interna) e resguardar interesses de acionistas e terceiros alheios a companhia (responsabilidade externa) ${ }^{71}$, o legislador estabeleceu padrões de conduta gerais e abstratos, consubstanciados nos deveres fiduciários previstos nos artigos 153 a 157 da Lei das S.A., que deverão orientar o comportamento dos administradores na condução dos negócios sociais, sem prejuízo de outros deveres que se

\footnotetext{
${ }^{70}$ Nesse sentido, Waldirio Bulgarelli reconhece que "a separação entre propriedade das ações e o poder de controle, que se acentua nas companhias abertas, vem gerando, além de medidas de proteção às minorias também um agravamento dos deveres impostos aos administradores relativamente ao corpo acionário e terceiros" (BULGARELLI, Waldirio. Apontamentos sobre a responsabilidade dos administradores das companhias. In: Revista de Direito Mercantil, Industrial, Econômico e Financeiro, v. 22, nº 50, abr./jun. 1983, p. 75).

${ }^{71}$ Conforme esclarece Marcelo Vieira Von Adamek, "a responsabilidade interna constitui critério de balanceamento dos poderes atribuídos pela lei e pelos estatutos aos administradores, assegurando que o seu exercício seja corretamente direcionado para a consecução do interesse da companhia; e a responsabilidade externa, voltada a sancionar os demais interesses também prestigiados pelo legislador (inclusive os interesses individuais dos acionistas" (ADAMEK, Marcelo Vieira Von. Op. Cit. p. 114).
} 
encontram dispersos no referido diploma legal ou implícitos em normas diversas.

Dentre os deveres fiduciários previstos na Lei das S.A., convém ressaltar, para os fins a que se propõe o presente trabalho, (i) o dever de diligência (artigo 153); (ii) o dever de agir de acordo com o interesse social (artigo 154); e (iii) o dever de lealdade (artigo. 155), cujo descumprimento poderá indicar, a depender da situação, uma atuação culposa ou dolosa do administrador e, por consequência, afetar a cobertura do seguro D\&O.

No que diz respeito ao dever de diligência, a Lei das S.A. esclarece que "[o] administrador da companhia deve empregar, no exercício de suas funções, o cuidado e diligência que todo homem ativo e probo costuma empregar na administração dos seus próprios negócios".

Por se tratar de conceito de difícil caracterização, o legislador recorre à figura do "homem ativo e probo" como parâmetro de conduta ${ }^{72}$. Contudo, tal como ressaltado por Flávia Parente, aos administradores impõe-se um nível de diligência superior ao do bonus pater famílias, que demandaria capacidade gerencial e competência profissional ${ }^{73}$.

Para facilitar a verificação do cumprimento do dever de diligência, a doutrina o tem descomposto em cinco diferentes aspectos: (i) o dever de se qualificar para o exercício do cargo; (ii) o dever de bem administrar; (iii) o dever de se informar; (iv) o dever de investigar; e (v) o dever de vigiar ${ }^{74}$.

\footnotetext{
${ }^{72}$ Nesse sentido, Flávia Parente esclarece que "O dever de diligência dos administradores de sociedades é de difícil definição, preferindo as diversas legislações de diferentes países não o conceber em concreto, mas em abstrato, recorrendo, para tanto, a figuras como a do bom pai de família, do comerciante ordenado e cuidadoso ou do homem de negócios consciencioso. Isto é, na maioria dos sistemas legais, a conduta do administrador deverá pautar-se pelo comportamento de um tipo médio, não sendo investigada a conduta que ele mesmo adotaria de acordo com a sua própria diligência. "(PARENTE, Flávia. $O$ dever de diligência dos administradores de sociedades anônimas. Rio de Janeiro: Renovar, 2005. p. 37).

${ }^{73}$ Ibidem, p. 41. Nesse sentido, vide também BULGARELLI, Waldirio. Op. Cit. pp. 77-84. Vide também: (MARTINS). Fran. Comentários à Lei das Sociedades Anônimas. vol. II. Rio de Janeiro: Forense, 1984, p. 362.

${ }^{74}$ EIZIRIK, Nelson. (et. al.). Mercado de Capitais - regime jurídico. $3^{\text {a }}$ Ed. Rio de Janeiro: Renovar, 2011. pp. 430-435.
} 
Em linhas gerais, a partir da análise de cada um desses "sub-deveres", é possível concluir que o administrador deverá atuar na condução dos negócios sociais de maneira informada, buscando adquirir os conhecimentos necessários acerca da atividade social e, em especial no momento da tomada da decisão, as informações a respeito das operações que serão implementadas, bem como analisando criticamente os dados fornecidos e apurando situações que sinalizem algum risco (red flags).

No que concerne ao dever fiduciário previsto no artigo 154 da Lei das S.A., entende-se que os poderes atribuídos pela lei aos administradores são poderes-funções, a serem exercidos visando o interesse da companhia, o qual, em última análise, pressupõe a consecução do escopo-meio, isto é, o objeto social, bem como do escopo-fim, a saber, a obtenção e a partilha de lucros entre os acionistas ${ }^{75}$.

Ao apontar o interesse social como o elemento que deve orientar a conduta do administrador, a Lei das S.A. procurou evitar que as atribuições e os poderes conferidos aos administradores fossem direcionados ao atendimento de seus interesses particulares ou daqueles que os elegeram, em desvio de poder ${ }^{76}$.

Nesse sentido, o artigo 154, $\S 2^{\circ}$ da Lei das S.A. prevê as seguintes vedações ao administrador: (i) a prática de ato de liberalidade ${ }^{77}$ à custa da companhia; (ii) tomar por empréstimo recursos ou bens da companhia ou utilizar os seus bens, serviços ou créditos, em proveito próprio, de

\footnotetext{
${ }_{76}^{75}$ ADAMEK, Marcelo Vieira Von. Op. Cit. p. 143.

${ }^{76}$ Nesse sentido, conceitua-se desvio de poder nos seguintes termos "o desvio de poder pode ocorrer quando os administradores das sociedades, embora observando formalmente as regras previstas no estatuto ou na legislação, delas se afastam substancialmente, ao conduzir-se de forma a atingir finalidades diversas das previstas nas normas estatutárias e legais" (EIZIRIK, Nelson. (et. al.). Mercado de Capitais ..., pp. 451-452). Também nesse sentido vide CAMPOS, Luiz Antônio de Sampaio Campos. Deveres e Responsabilidades. In: LAMY FILHO, Alfredo; PEDREIRA, José Luiz Bulhões (Org.) Direito das Companhias, $2^{\mathrm{a}}$ ed. Rio de Janeiro: Forense, 2017, pp. 816-817.

77 "Por liberalidade, entende-se o ato que 'importando em benefício a outrem, nada proporciona, em troca, à entidade coletiva'. (...) Insta advertir que certos atos são gratuitos na sua aparência, mas não na sua essência, ou porque têm caráter remuneratório, ou por estarem inseridos no contexto maior de uma atividade empresarial" ADAMEK, Marcelo Vieira Von. Op. Cit. pp. 149150.
} 
sociedade em que tenha interesse ou de terceiros, sem prévia autorização; (iii) receber de terceiros, sem autorização estatutária ou assemblear, qualquer modalidade de vantagem pessoal, direta ou indireta, em razão do exercício de seu cargo.

Em estreita ligação ao dever de agir no interesse da companhia, o dever de lealdade pressupõe que, por se encontrarem em uma posição fiduciária, os administradores deverão atuar segundo os princípios da boa-fé, tendo em vista os interesses sociais $^{78}$, razão pela qual não poderão se antepor à companhia, seja para auferir vantagem, seja para impedir que ela se beneficie $^{79}$.

Nos termos da redação do artigo 155, a ideia é que o administrador deve servir à companhia e não dela se servir, de modo que as informações que obtiverem e os atos que praticarem no exercício do cargo deverão se pautar pela mais estrita lealdade à companhia ${ }^{80}$.

Desse modo, estão entre as condutas vedadas ao administrador: (i) a usurpação de oportunidades comerciais de que tenha conhecimento em razão do cargo, em benefício próprio ou de outrem; (ii) omissão no exercício ou proteção de direitos da companhia; (iii) o não aproveitamento de oportunidades de negócio de interesse da companhia visando à obtenção de vantagens; (iv) aquisição de bem ou direito que sabe necessário à companhia, com o objetivo de revender com lucro ${ }^{81}$.

Verifica-se, portanto, que, muito embora tenha elencado os principais deveres dos administradores de sociedades anônimas, o legislador não pretendeu esgotar toda a esfera de atuação do administrador, ditando todos

\footnotetext{
${ }^{78}$ EIZIRIK, Nelson. (et. al.). Mercado de capitais (...), p. 456.

${ }^{79}$ CAMPOS, Luiz Antonio de Sampaio. Op. Cit. p. 821.

${ }^{80}$ Ibidem, p. 821.

${ }^{81}$ Ainda assim, conforme ressaltado por Luiz Antonio de Sampaio Campos, a extensão do dever de lealdade vai muito além das hipóteses previstas nos incisos do artigo 155 da Lei das S.A (Ibidem, p. 822).
} 
os atos que poderiam, não poderiam ou deveriam ser praticados pelo administrador em cada situação da vida empresarial ${ }^{82}$.

Nesse sentido, Norma Parente ressalta que:

"A impossibilidade prática e a falibilidade a que se sujeita o legislador, na tentativa de prever todo o campo de atuação do administrador, demandaram que a lei fosse ampla e flexível, de modo a abranger situações diversas, infinitas e práticas políticoeconômicas dos vários tipos societários, ao longo do tempo. Tal flexibilidade permite, inclusive, permanente adequação às mutações sociais. A opção legislativa por previsão genérica da conduta esperada do administrador consiste em uma resposta à inumerável gama de atividades e circunstâncias que podem permitir a sua atuação, o que escaparia às possibilidades de expressa previsão legal" ${ }^{83}$.

Em outras palavras, ao delimitar standards genéricos, a Lei das S.A. fixa orientações gerais ou modelos de comportamento que deverão informar a conduta dos administradores, mas não enumera todos os deveres e obrigações destes profissionais. Entende-se, portanto, que, salvo as restrições estabelecidas na lei e no estatuto social, os administradores dispõem de discricionariedade para conduzir os negócios sociais.

Assim, verificando-se que a atuação do administrador ocorreu dentro dos limites de discricionariedade a ele conferidos pelas normas legais e estatutárias e em observância aos padrões de conduta impostos pela legislação societária, ainda que dela decorram prejuízos para a companhia, seus acionistas ou terceiros, não importará responsabilidade pessoal do administrador. Isso porque a obrigação assumida pelo administrador quando de sua investidura no cargo da administração ou da aceitação de funções de gestão é uma obrigação de meio e não de resultado ${ }^{84}$.

Destas conclusões é possível extrair o conceito de ato regular de gestão previsto no artigo 158 da Lei das S.A., segundo o qual:

\footnotetext{
${ }^{82}$ ADAMEK, Marcelo Vieira Von. Op. Cit. p. 119.

${ }^{83}$ PARENTE, Norma Jonssen. Limites da responsabilidade dos administradores pela indenização de prejuízos. In: Revista de Direito Bancário e do Mercado de Capitais, vol. 31, jan. 2006. pp. 33 34.

${ }^{84}$ ADAMEK, Marcelo Vieira Von. Op. Cit. p. 197. Vide também: LUCENA, José Waldecy. Das sociedades anônimas: comentários à lei (arts. 121 a 188). vol. 2. Rio de Janeiro: Renovar, 2009. p. 561; e PARENTE, Flávia. Op. Cit. p. 50.
} 
"Art. 158. O administrador não é pessoalmente responsável pelas obrigações que contrair em nome da sociedade e em virtude de ato regular de gestão; responde, porém, civilmente, pelos prejuízos que causar, quando proceder:

(i) dentro de suas atribuições ou poderes, com culpa ou dolo; ou

(ii) com violação da lei ou do estatuto. ".

Conforme ressaltado por José Alexandre Tavares Guerreiro ${ }^{85}$, ao elaborar a redação do referido artigo, o legislador teria incorrido em verdadeira tautologia, visto que a parte inicial do dispositivo prevê que o administrador não será responsável por ato regular de gestão, cuja definição se depreende a partir da interpretação a contrario sensu da parte final da norma, em que são fixadas as hipóteses de responsabilização do administrador.

Não obstante, é possível concluir, sem maiores dificuldades, que o ato regular de gestão é aquele praticado pelo administrador nos limites de suas atribuições e sem violação da lei ou do estatuto social ${ }^{86}$.

Com efeito, a regra geral de (ir)responsabilidade do administrador, nos termos previstos no dispositivo transcrito acima, compatibiliza-se perfeitamente com os princípios norteadores da regra da decisão negocial (business judgment rule), nos moldes desenvolvidos pelas cortes inglesas e norte-americanas, ainda que, tal como ressaltado por Pedro Henrique Castello Brigagão, não pareça ser a regra do caput do artigo 158 da Lei das S.A. a responsável última pela recepção desta regra no direito brasileiro ${ }^{87}$.

Em vista de sua crescente relevância no direito brasileiro, com o desenvolvimento de estudos sobre o tema e análise mais aprofundada de sua compatibilização com o ordenamento jurídico nacional, convém descrever,

\footnotetext{
${ }^{85}$ GUERREIRO, José Alexandre Tavares. Responsabilidade dos administradores de sociedades anônimas. In: Revista de Direito Mercantil, Industrial, Econômico, Financeiro, n. 42, abr./jun. 1981, p. 73.

${ }^{86}$ EIZIRIK, Nelson. A Lei das S/A Comentada. Volume III - $2^{\mathrm{a}}$ edição (artigos 138 a 205). São Paulo: Quartier Latin, 2015. p. 173.

87 "No direito brasileiro, a business judgment rule não está abarcada por um outro artigo lega. A despeito de se poder dizer que a primeira parte do art. 158 - 'o administrador não é pessoalmente responsável pelas obrigações que contrair em nome da sociedade e em virtude de ato regular de gestão - acaba por concentrar os princípios basilares da regra da decisão negocial e é com ela compatível, não parece ser tal norma a responsável última pela recepção dos preceitos de tal regra no direito brasileiro" (BRIGAGÃO, Pedro Henrique Castello. A Administração de Companhias e a Business Judgment Rule. São Paulo: Quartier Latin, 2017. p. 178).
} 
ainda que brevemente, os principais elementos que compõem esta regra, que apresenta importantíssima aplicação prática como padrão de revisão (standard of review) ${ }^{88}$ das decisões negociais.

Em linhas gerais, a partir da aplicação da business judgment rule "presume-se que, ao tomarem uma decisão empresarial, os administradores agiram com os conhecimentos e informações adequadas $e$ de boa fé, acreditando que ela atende aos interesses sociais" ${ }^{89}$.

Diante de tal presunção, transfere-se o ônus da prova àquele que pretende contestar a decisão negocial, cabendo a este demonstrar que o administrador agiu de má-fé, com falta de diligência ou em desrespeito aos interesses sociais. Caso não se desincumba deste ônus, assegura-se proteção à discricionariedade do administrador e, por conseguinte, à decisão negocial, que não poderá ser reexaminada em seu mérito ou, ainda, substituída por outra que o julgador entenda mais razoável ${ }^{90}$.

Tal como se propõe o caput do artigo 158 da Lei das S.A., a regra da decisão negocial tem por objetivo assegurar a proteção da discricionariedade dos administradores de companhias que atuem dentro dos limites legais e estatutários.

Hipótese distinta da regra de decisão negocial é aquela prevista no artigo $159, \S 6^{\circ}$ da Lei das S.A., nos termos da qual "o juiz poderá reconhecer $a$ exclusão da responsabilidade do administrador, se convencido de que este agiu de boa-fé e visando ao interesse da companhia".

\footnotetext{
${ }^{88}$ Ressalta-se que muito embora a acepção da business judgment rule como padrão de revisão (standard of review) de decisões negociais seja majoritária entre a doutrina e a jurisprudência norte-americanas, existem ainda outras formulações acerca desta regra. Nesse sentido, em sua obra referenciada na nota de rodapé $\mathrm{n}^{\circ} 28$ acima, Pedro Henrique Castello Brigagão apresenta ainda as proposições gerais da abstention doctrine e menciona ainda a existência de outros formuações, tal como o gross negligence standard e a immunity doctrine.

${ }^{89}$ EIZIRIK, Nelson. Op. Cit. p. 190. Também nesse sentido, Pedro Henrique Castello Brigagão esclarece que "a business judgment rule constitui uma presunção de que os administradores, no exercício de suas funções, sempre agem de boa-fé, de maneira informada e no interesse da companhia" (BRIGAGÃO, Pedro Henrique Castello. Op. Cit. p. 119). Vide também PARENTE, Flávia. Op. Cit. p. 71.

${ }^{90}$ BRIGAGÃO, Pedro Henrique Castello. Op. Cit. p. 120.
} 
Isso porque, neste caso, a responsabilidade do administrador está plenamente configurada, tendo sido preenchidos todos os requisitos necessários para tanto, conforme descritos adiante, autorizando-se, no entanto, o juiz a considerar a boa fé e a atuação no interesse da companhia para afastar os efeitos patrimoniais decorrentes do reconhecimento da responsabilidade do administrador ${ }^{91}$.

Em que pesem as distinções inerentes a cada situação, tem-se que tanto a hipótese de ato regular de gestão, quanto a aplicação da regra da decisão negocial ou da possibilidade conferida pelo artigo $159, \S 6^{\circ}$ da Lei das S.A. importam a não responsabilização do administrador. Além disso, mencionase, ainda, a aprovação das contas e demonstrações financeiras como hipótese diversa de exoneração de responsabilidade dos administradores, por meio da qual os acionistas, reunidos em assembleia, conferem o quitus à administração relativamente aos atos de gestão tomados durante determinado exercício social (art. 134, $\S 3^{\circ}$ da Lei das S.A.).

Concluiu-se, portanto, que, nestas circunstâncias, o administrador restringe a sua exposição ao risco, posto que afasta as hipóteses de responsabilização previstas na legislação societária. Desse modo, não há que se falar em cobertura do seguro $\mathrm{D} \& \mathrm{O}$ para indenizações posto que ausente o próprio fato gerador do sinistro, qual seja a responsabilização do administrador por ato praticado na gestão social.

Passa-se, então, a examinar as hipóteses de responsabilização do administrador previstas na Lei das S.A.

Como visto inicialmente, o diploma legal (artigo 158, incisos I e II) prevê duas situações em que o administrador responderá pessoalmente pelos prejuízos causados: (i) quando atuar dentro de suas atribuições ou poderes, com culpa ou dolo; ou (ii) quando violar a lei ou o estatuto social.

\footnotetext{
${ }^{91}$ Ibidem, p. 174.
} 
Em ambas as hipóteses, conforme regra geral de responsabilidade civil, caberá ao sujeito lesado demonstrar o ato ilícito, o nexo de causalidade entre o evento danoso e a conduta do administrador e o próprio dano. Diverge-se, no entanto, quanto à natureza de tal responsabilidade, se objetiva ou subjetiva, sendo que, neste último caso, agregar-se-ia ainda o elemento da culpa lato sensu para a configuração da responsabilidade ${ }^{92}$.

A redação do inciso I não deixa espaço para questionamentos, visto que faz referência expressa ao elemento subjetivo (culpa ou dolo) como condicionante da responsabilidade do administrador. Trata-se, portanto, sem maiores dúvidas, de hipótese de responsabilidade subjetiva.

O inciso I do artigo 158 da Lei das S.A. cuida da hipótese em que o administrador, atuando dentro de suas atribuições e de conformidade com os poderes que a lei e o estatuto lhe conferem, age com culpa ou dolo, faltando com o dever de diligência a ele imposto pelo artigo 153 da Lei das S.A. ou desvirtuando as finalidades da administração, buscando benefício próprio ou em favor de terceiro ${ }^{93}$.

Como exemplo de atuação dolosa, menciona-se a celebração de contrato em nome da sociedade movido por interesses escusos e cujas condições o administrador sabe não serem favoráveis à companhia. Ainda no caso de contratações celebradas em nome da sociedade é possível vislumbrar conduta culposa do administrador, em que faltando com a diligência esperada de administrador profissional, celebra contrato que importe prejuízos à companhia ${ }^{94}$.

Cumpre ressaltar que a companhia concorre na responsabilidade por danos causados a terceiros em razão de atos praticados pelo administrador dentro de suas atribuições com culpa ou dolo. Isso porque, tal como exposto

\footnotetext{
${ }^{92}$ EIZIRIK, Nelson. Responsabilidade civil e administrativa do diretor de companhia aberta. In: Revista de Direito Mercantil, Industrial, Econômico e Financeiro. Ano XXIII. n ${ }^{\circ}$ 56, out.-dez., 1984, p. 52.

${ }^{93}$ GUERREIRO, José Alexandre Tavares. Op. Cit., p. 77.

${ }^{94}$ Ibidem, p. 78.
} 
acima, observado o limite das atribuições e dos poderes conferidos ao administrador pela lei e pelo estatuto social, entende-se que este último atuou como órgão próprio da sociedade, expressando a vontade social, razão pela qual eventuais prejuízos decorrentes de sua atuação deverão ser suportados também pela companhia ${ }^{95}$.

É com relação ao inciso II do referido dispositivo que surgem as divergências doutrinárias quanto à natureza da responsabilidade do administrador, dado que, neste caso, não há qualquer referência à atuação culposa ou dolosa do administrador, mas tão somente à verificação de violação à lei ou ao estatuto social.

Sobre o tema desenvolveram-se três correntes distintas. A primeira delas, defendida por Modesto Carvalhosa e fundamentando-se na teoria do "risco do dano criado" 96 , entende que a hipótese do inciso II consignaria a responsabilidade objetiva do administrador, dispensando a demonstração de culpa ou dolo ${ }^{97}$. Por outro lado, há quem entenda, em linha com o posicionamento de Marcelo Von Adamek e Fabio Ulhoa Coelho, não haver distinção entre a natureza da responsabilidade prevista nos incisos I e II do artigo 158. Neste caso, parte-se da premissa que a conduta culposa (lato sensu) do administrador resulta da violação a dever jurídico - que, no limite, tem sua fonte na lei - e, por conseguinte, importa ato ilícito, da mesma forma que a violação da lei configura comportamento culposo do agente. Por essa razão, entender-se-ia que o artigo 158 da Lei das S.A. teria

\footnotetext{
${ }^{95}$ EIZIRIK, Nelson. Responsabilidade Civil (...). pp. 54-55.

${ }^{96}$ Segundo Modesto Carvalhosa, "ao infringir a lei ou o estatuto, o administrador cria o risco do dano para a companhia, independentemente do proveito pessoal que lhe tenha trazido tal risco, $e$, consequentemente, da intenção de favorecer a si próprio, a terceiros, ou de prejudicar aquele que sofre esse risco" (CARVALHOSA, Modesto. Responsabilidade civil de administradores e de acionistas controladores perante a Lei das S/A. In: Revista dos Tribunais, vol. 699, jan. 1994, p. 37).

97 No que diz respeito à adoção da responsabilidade objetiva, Waldirio Bulgarelli afirma que "levar ao extremo da responsabilidade objetiva pura, meramente causal, a situação dos administradores seria quando menos uma demasia, pois este regime severo afastando, via de regra, os verdadeiros mentores (controladores) recairia sobre os administradores assalariados que também comumente não possuem bens suficientes. (...) Dispensar a vítima da prova da culpa e impedir o autor de demonstrar sua isenção, no âmbito da administração das companhias, parece, a esta altura do nosso desenvolvimento, excessivo e em muitos casos inócuo, servindo como desestimulantes para o exercício dos cargos" (BULGARELLI, Waldirio. Op. Cit. p. 96)
} 
se limitado a repetir, sem a mesma precisão, a regra geral da responsabilidade civil por ato ilícito ${ }^{98}$.

Não obstante, a doutrina majoritária ${ }^{99}$ afirma, ao que parece de forma acertada, que, caracterizado o ato ilícito do administrador, nos termos do inciso II, haveria uma presunção relativa de culpa, invertendo-se o ônus da prova, de modo que caberia ao próprio administrador demonstrar que, embora tenha violado a lei ou o estatuto, teria agido sem culpa ou dolo.

Nesse sentido, Waldirio Bulgarelli defende que a análise sistemática do regime de responsabilidade dos administradores previsto na Lei das S.A., revela que a ratio legis está voltada para dar ampla possibilidade aos administradores de justificar seus atos ${ }^{100}$. Poderia o administrador demonstrar, por exemplo, que a violação à lei ou ao estatuto foi a única alternativa possível para favorecer a companhia diante de uma situação de impasse ou, ainda, que tal violação não decorreu da adoção de interpretação distinta do texto legal, devidamente embasada por opiniões técnicas sobre a matéria.

Vale ressaltar, em linha com as considerações iniciais apresentadas acerca dos deveres fiduciários previstos na Lei das S.A., que a apreciação da culpa stricto sensu do administrador para fins de responsabilidade civil (incisos I e II) guarda estreita relação com a verificação do cumprimento do dever de diligência.

No que diz respeito à responsabilidade solidária da companhia por atos causados a terceiros, entende-se que, via de regra, na hipótese de violação à

\footnotetext{
${ }^{98}$ ADAMEK, Marcelo Vieira Von. Op. Cit. pp. 218-219. Ao questionar-se acerca do porquê de a lei das S.A. fazer referência em incisos distintos do artigo 158 a hipóteses redutíveis a uma só (violação culposa de dever legal ou estatutário constitui ato ilícito do administrador), Marcelo Vieira Von Adamek concluiu que a principal motivação do legislador seria distinguir as hipóteses em que a companhia responde solidariamente junto ao administrador pelos danos causados a terceiros (ADAMEK, Marcelo Vieira Von. Op. Cit. pp. 221-225).

${ }^{99}$ Nesse sentido, convém mencionar o posicionamento de Nelson Eizirik (Op. Cit. pp. 158-159), Norma Jonssen Parente (Op. Cit. p. 31), José Alexandre Tavares Guerreiro (Op. Cit. p. 77), Luiz Antônio de Sampaio Campos (CAMPOS, Luiz Antônio de Sampaio. Op. Cit, p. 876) e Waldirio Bulgarelli (Op. Cit. pp. 96-97).

${ }^{100}$ BULGARELLI, Waldirio. Op. Cit. p. 97.
} 
lei ou ao estatuto (inciso II) ${ }^{101}$, os atos praticados pelo administrador não obrigam a sociedade, exceto nos casos em que o prejudicado for terceiro de boa-fé ou, ainda, quando a companhia houver ratificado o ato ou tirado proveito de seus efeitos ${ }^{102}$.

Delimitado o regime de responsabilidade civil dos administradores, convém analisar os instrumentos processuais assegurados pela Lei das S.A. aos sujeitos lesados pelos atos praticados na gestão social, que poderão ser (i) a própria companhia; (ii) os acionistas; e/ou (iii) terceiros.

No que diz respeito aos prejuízos causados ao patrimônio da companhia, o artigo 159 da Lei das S.A. estabelece as regras que orientarão a propositura da ação social. A decisão de buscar a responsabilização dos administradores em juízo deverá ser submetida à assembleia geral, ordinária ou extraordinária, cuja deliberação sobre a matéria é condição de procedibilidade da ação, seja pela própria companhia, seja por acionistas. Aprovada a propositura da ação, ficarão impedidos de atuar na gestão social os administradores contra os quais será movida a demanda, devendo ser substituídos na mesma assembleia ${ }^{103}$.

Caberá então aos demais administradores tomarem todas as providências necessárias à propositura da ação, que será movida em nome da companhia, legitimada ordinária, atuando os administradores tão somente como seus representantes legais. Trata-se, neste caso, da ação social ut universi ${ }^{104}$.

\footnotetext{
${ }^{101}$ Nesse sentido, José Alexandre Tavares Guerreiro esclarece que, via de regra, os atos praticados pelo administrador em violação à lei ou ao estatuto não obrigam a sociedade, posto que só será possível considerar o administrador como órgão social na medida em que atue dentro dos limites de suas atribuições, em observância à delimitação imposta pelo objeto social estatutário e sob o enfoque do interesse social, parâmetros estes que poderiam ser verificados por terceiros a partir da estrutura formal de poder de cada companhia. No entanto, o próprio autor reconhece que tal orientação é mitigada em benefício da boa-fé do terceiro que se relaciona com a companhia, uma vez que se comprova que, a despeito do regime de publicidade das sociedades anônimas, a verificação de poderes não é um hábito que acompanha os indivíduos comuns. (GUERREIRO, José Alexandre Tavares. Op. Cit. p. 75).

${ }^{102}$ EIZIRIK, Nelson. Op. Cit. p. 177.

${ }^{103}$ Ibidem, p. 183.

${ }^{104}$ Ibidem, p. 186.
} 
É possível, no entanto, que a ação social (ut singuli) seja movida por acionistas minoritários em duas hipóteses distintas: (i) caso a propositura da ação seja aprovada em assembleia, mas os administradores não promovam a ação no prazo de três meses, qualquer acionista poderá fazê-lo; ou (ii) caso os acionistas deliberem não propor a ação de responsabilidade, acionistas titulares de, pelo menos, $5 \%$ do capital social poderão ajuizá-la ${ }^{105}$.

Ressalta-se, desde logo, que em ambos os casos a ação é movida buscando satisfazer os interesses da companhia, isto é, a recomposição dos danos causados ao patrimônio social, de modo que, em eventual condenação, as indenizações pagas pelos administradores serão destinadas à sociedade. Nestas situações, os acionistas são indicados pela Lei das S.A. (artigo $159, \S \S 3^{\circ}$ e $4^{\circ}$ ) apenas como legitimados extraordinários para a propositura da ação, atuando como substitutos processuais ${ }^{106}$.

Qualquer que seja a espécie de ação social, ut universi ou ut singuli, havendo deliberação prévia em assembleia geral ordinária aprovando as demonstrações financeiras e as contas da administração e, por conseguinte, exonerando os administradores de responsabilidade civil ${ }^{107}$ não poderá ser proposta a ação sem a desconstituição prévia da referida deliberação assemblear. Tal deliberação poderá ser desconstituída nos casos de erro, dolo, fraude ou simulação, conforme previsto no artigo $134, \S^{\circ}$ da Lei das S.A. ou, ainda, por meio da invalidação da própria assembleia.

Em vista do objeto do presente trabalho, convém tecer algumas considerações adicionais acerca da ação ut singuli movida por acionistas representantes de 5\% do capital social. Nestas circunstâncias, os acionistas minoritários atuam a despeito da vontade manifestada pela assembleia geral, o que importa em algumas consequências práticas para a propositura

\footnotetext{
${ }^{105}$ Ibidem. p. 187.

${ }^{106}$ Ibidem, p. 188.

107 Conforme já reconhecido em decisão da CVM no âmbito do Processo Administrativo Sancionador CVM n ${ }^{\circ}$ 24/2003, Dir. Rel. Wladimir Castelo Branco, julg. em 09 de junho de 2005, o quitus concedido aos administradores pela assembleia geral não elide eventual responsabilidade administrativa.
} 
da ação. Em primeiro lugar, os administradores contra os quais deve ser movida a demanda não são afastados da administração, por se entender que a não aprovação da ação pela maioria dos acionistas seria um indicativo de que a confiança em tais profissionais estaria mantida ${ }^{108}$.

Ademais, todos os custos processuais e despesas com honorários advocatícios, bem como os riscos de eventual sucumbência seriam suportados pessoalmente pelos acionistas minoritários, enquanto que, por outro lado, os benefícios resultantes do sucesso da demanda seriam partilhados entre todos os acionistas e, por conseguinte, as vantagens pessoais do autor da ação seriam indiretas e dissipadas ${ }^{109}$. Por estas razões, ao contrário do que se verifica no sistema norte-americano, conforme mencionado acima, o estímulo à propositura da ação social por acionistas minoritários é muito baixo ${ }^{110}$.

No que concerne aos prejuízos causados a acionistas e terceiros, o artigo $159, \S 6^{\circ}$ da Lei das S.A. prevê expressamente que a propositura da ação social não exclui a possibilidade de acionistas ou terceiros prejudicados moverem ação diretamente em face dos administradores.

Neste caso, a ação promovida por acionistas ou terceiros prejudicados visa à reparação de seu patrimônio pessoal, razão pela qual esta ação se reserva aqueles que foram diretamente prejudicados pelos atos praticados pelo administrador, de modo que se exige a demonstração do dano direto. Os danos sofridos indiretamente pelos acionistas em virtude dos prejuízos

\footnotetext{
${ }^{108}$ CARVALHOSA, Modesto. Op. Cit. p. 41.

109 Tratamento distinto foi conferido pelo legislador às ações propostas em face da sociedade controlador pelos danos causados à controlada. Neste caso, o artigo 246, §2 $2^{\circ}$ da Lei das S.A. prevê que, em caso de condenação da sociedade controladora, esta última estará obrigada a pagar ao autor da ação um prêmio de 5\%, bem como honorários advocatícios de $20 \%$.

${ }^{110}$ Em julgamento recente da CVM no âmbito do Processo Administrativo Sancionador CVM n ${ }^{\circ}$ RJ2014/10556, foi reconhecida a ausência de estímulos à propositura da ação derivada por acionistas minoritários, nos termos do voto do Diretor Gustavo Borba.
} 
sofridos pela companhia não servirão de fundamento para a ação individual $^{111}$.

Ainda que com relação à ação individual os acionistas tenham um estímulo maior à sua propositura, tendo em vista que eventual indenização decorrente do sucesso da demanda será destinada integralmente ao autor da ação, enfrenta-se ainda outro obstáculo à satisfação de seus interesses: os limites patrimoniais do administrador. Especialmente nas ações em que não concorre a sociedade, o êxito na demanda nem sempre assegura a reparação dos danos sofridos pelo acionista ou terceiro lesado, visto que, muitas vezes, o patrimônio do administrador não é suficiente para suportar os custos da indenização ${ }^{112}$.

\subsubsection{Responsabilidade Administrativa}

Também na esfera administrativa no âmbito do poder disciplinar da CVM aprecia-se a responsabilidade de administradores de companhias abertas à luz das disposições da Lei das S.A. e da legislação sobre o mercado de capitais.

Nos termos do artigo $8^{\circ}$, inciso $\mathrm{V}$, da Lei $\mathrm{n}^{\circ} 6.385 / 76^{113}$, compete à CVM a fiscalização e a inspeção das companhias abertas, atribuindo-se a esta autarquia o poder de "apurar, mediante processo administrativo, atos ilegais e práticas não equitativas de administradores, membros do conselho fiscal e acionistas de companhias abertas, dos intermediários e dos demais participantes do mercado", conforme artigo. $9^{\circ}$, inciso $\mathrm{V}$ da referida lei ${ }^{114}$.

\footnotetext{
111 CARVAlHOSA, Modesto. Op. Cit. p. 6. Vide também GUERREIRO, José Alexandre Tavares. Op. Cit. p. 83.

${ }^{112}$ GATTAZ, Luciana de Godoy Penteado. A responsabilidade civil dos administradores de companhias aberas não financeiras e o seguro D\&O. In: Revista de Direito Bancário e do Mercado de Capitais, ano 19, vol. 74, out.-dez, 2016. p. 65.

${ }^{113}$ Art. $8^{\circ}$ Compete à Comissão de Valores Mobiliários: (...) V - fiscalizar e inspecionar as companhias abertas dada prioridade às que não apresentem lucro em balanço ou às que deixem de pagar o dividendo mínimo obrigatório.

${ }^{114}$ Art. $9^{\circ}$ A Comissão de Valores Mobiliários, observado o disposto no $\S 2^{\circ}$ do art. 15 , poderá (...) $\mathrm{V}$ - apurar, mediante processo administrativo, atos ilegais e práticas não eqüitativas de administradores, membros do conselho fiscal e acionistas de companhias abertas, dos intermediários e dos demais participantes do mercado;
} 
O enfoque da atuação administrativa, contudo, é distinto.

Ao tempo que na esfera cível o reconhecimento da responsabilidade do administrador impõe a reparação dos prejuízos causados a terceiros ou, mesmo, à própria companhia, mediante o exercício em juízo da pretensão indenizatória e observadas as condições de legitimidade e cabimento da ação descritos no item 2.1.1. acima, a configuração da responsabilidade administrativa pressupõe a instauração de um procedimento administrativo conduzido pelo ente regulador do mercado de capitais, que pode ter como consequência a aplicação das penalidades previstas no artigo 11, da Lei $\mathrm{n}^{\mathrm{o}} 6.385 / 76$.

Nota-se, portanto, que, enquanto a responsabilização civil do administrador busca a recomposição dos danos causados a partir de ilicitudes verificadas na gestão social, a responsabilização administrativa revela um propósito disciplinar, voltado não à proteção de interesses particulares, mas ao adequado funcionamento e desenvolvimento do mercado de valores mobiliários. A tutela administrativa volta-se não apenas a um único indivíduo lesado pela conduta do administrador, mas à coletividade que participa do mercado de valores mobiliários ${ }^{115}$.

Dessa forma, o dano, cuja demonstração é requisito indispensável para a caracterização da responsabilidade civil, não parece ser elemento condicionante da responsabilidade administrativa. Isso porque, com relação a determinadas ilícitos, o resultado da conduta do agente não seria indispensável para a sua configuração, bastando a verificação do descumprimento da norma. Em outros casos, os prejuízos decorrentes da infração à lei são causados não a sujeitos determinados ou determináveis, mas ao mercado como um todo.

$\overline{{ }^{115} \text { CARA, Marília de. Op. Cit. p. } 71 .}$ 
No que diz respeito ao tema, a CVM manifestou o seu entendimento em algumas oportunidades ${ }^{116}$, esclarecendo que, em vista da transposição de determinados institutos e estruturas do direito penal ao procedimento administrativo sancionador, também na esfera administrativa seria possível identificar infrações classificadas como de "mera conduta", isto é, ilícitos que para a sua caracterização dependem tão somente da conduta omissiva ou comissiva do agente contrária à lei, sendo que o dano ou a ameaça a determinado bem jurídico seria verificável a partir da própria conduta ${ }^{117}$. Nessas situações, a existência ou não de prejuízos decorrentes da conduta ilícita poderia vir a ser considerada na dosimetria da pena a ser aplicada ao infrator, mas não impediria a sua condenação.

Segundo Nelson Eizirik, a dispensa do dano como elemento necessário à responsabilização dos acusados seria, em princípio, discutível ${ }^{118}$, visto que conduziria a crença simplista de que qualquer violação a dispositivo legal deve ser objeto de sanção, dispensando uma avaliação dos valores tutelados pela norma.

\footnotetext{
${ }^{116}$ Processo Administrativo Sancionador CVM no 14/03, Dir. Rel. Pedro Marcílio, julg. em 15 de maio de 2007; Processo Administrativo Sancionador CVM no RJ2007/14515, Dir. Rel. Sergio Weguelin, julg. em 16 de dezembro de 2008; Processo Administrativo Sancionador CVM ${ }^{\circ}$ RJ2005/0098, Dir. Rel. Sergio Weguelin, julg. em 18 de dezembro de 2007; Processo Administrativo Sancionador CVM n ${ }^{\circ}$ RJ2010/1088, Dir. Rel. Otavio Yazbek, julg. em 30 de outubro de 2012; e Processo Administrativo Sancionador CVM no RJ2002/6413, Dir. Rel. Sergio Weguelin, julg. em 14 de dezembro de 2005.

${ }_{117}$ Nesse sentido, destaca-se o seguinte trecho da declaração de voto do Diretor Eli Loria no âmbito do Processo Administrativo Sancionador CVM n ${ }^{\circ}$ RJ2007/14515, julgado em 03 de março de 2009, Dir. Rel. Sergio Weguelin: "Feitas as considerações e concessões devidas quando da transposição dos institutos e estruturas penais ao campo administrativo sancionador, verifica-se que a doutrina penal, no que respeita ao resultado, classifica os crimes em materiais, formais e os de mera conduta. $O$ ilícito de mera conduta seria aquele em que a consumação não exige um resultado naturalístico, exaurindo-se com a própria ação ou omissão do agente. São crimes que encontram seu suporte natural apenas na ação ou na omissão do agente ativo e a maior parte da doutrina reconhece como ponto de distinção dos crimes de mera conduta a presunção legal de uma ofensa a um determinado bem jurídico. Por essa razão, seria possível afirmar que o resultado natural decorrente do crime de mera conduta não interessa para o direito penal, sendo que o dano ou o perigo ao bem jurídico se subsume na própria conduta. A doutrina relaciona, como exemplos, entre outros, a violação de domicílio (art. 150 do Código Penal), o ato obsceno (art. 233) e a omissão de notificação de doença (art. 269). Assim, verifica-se a possibilidade de aplicação da mesma classificação para as infrações administrativas e é possível afirmar que, do ponto de vista da importância do resultado, existem determinados tipos administrativos que dele prescindem para sua configuração".

${ }^{118}$ EIZIRIK, Nelson. Op. Cit. p. 58.
} 
Nesse sentido, o autor afirma que "há inúmeros casos de infrações à lei que não acarretam sanções, ou porque pode o aplicador da lei concluir que sua imposição resultaria inócua ou despropositada, ou porque elas simplesmente não estão previstas" 119.

Tal preocupação em assegurar a maior efetividade da atuação administrativa na regulação do mercado de valores mobiliários parece ter inspirado também o legislador na redação do $\S^{\circ}$, do artigo $9^{\circ}$ da Lei ${ }^{\circ}$ 6.385/1976, segundo o qual deverão ser priorizadas na atuação do ente regulador as infrações de natureza grave, cuja sanção proporcione maior efeito educativo e preventivo, em linha com os princípios da finalidade, da razoabilidade e da eficiência que norteiam a atuação administrativa.

Convém ressaltar que, em razão do propósito disciplinar da responsabilidade administrativa, cujo reconhecimento poderá culminar com a aplicação de uma sanção ao acusado, além da observância das garantias de ampla defesa e contraditório asseguradas expressamente no texto constitucional tanto em processo judicial quanto em processo administrativo, nos termos do artigo $5^{\circ}$, inciso LV, exige-se ainda que sejam delimitados com clareza os pressupostos de aplicação da norma e a descrição das faltas e penas nas quais possa incorrer o administrador ou outro participante do mercado ${ }^{120}$.

\subsubsection{Aspectos da responsabilidade administrativa}

Não obstante as distinções entre as esferas de responsabilização do administrador, ressalta-se que, tal como na esfera cível, a responsabilidade do administrador depende da demonstração de culpa lato sensu, sendo inadmissível a responsabilidade objetiva em procedimento disciplinar, observados os princípios do processo sancionador ${ }^{121}$.

\footnotetext{
${ }^{119}$ Ibidem, p. 58.

${ }^{120}$ Ibidem, p. 59. Vide também SANTOS, Alexandre Pinheiro dos; OSÓRIO, Fábio Medina; WELLISCH, Julya Sotto Mayor. Mercado de Capitais - Regime Sancionador. São Paulo: Saraiva, 2012, pp. 42-47.

${ }^{121}$ Ibidem, p. 59. Vide também: CARVALHOSA, Modesto. Op. Cit., p. 40.
} 
Diante da verificação de descumprimento legal ou estatutário por parte do administrador, autoriza-se a presunção de culpa. Ainda assim, é necessária a demonstração da participação concreta e individual do acusado no ato ilícito objeto de apuração. Isso porque, em razão do caráter sancionador do processo administrativo, a individualização da responsabilidade é indispensável, afastando-se qualquer possibilidade de comunicabilidade da culpa ${ }^{122}$.

Esta ressalva é especialmente importante para o caso de atos praticados por administradores em deliberações de órgãos colegiados. Ainda que se entenda que a manifestação de vontade de órgãos colegiados é una, a eventual responsabilização de seus membros deve considerar a conduta individualizada de cada administrador. Vigora, portanto, o princípio da culpa concreta $^{123}$.

Assim, para que a entidade reguladora possa aplicar uma penalidade ao administrador em decorrência de ato ilícito praticado na gestão da companhia, ela deve estar convencida da culpa própria, concreta e individual do acusado, seja porque os elementos levantados ao longo do inquérito administrativo são suficientes e permitem tal conclusão, seja porque, diante do descumprimento da norma legal ou estatutária, o administrador não logrou demonstrar a ausência de culpa ${ }^{124}$.

Nesse sentido, a Deliberação CVM nº 538, de 05 de março de 2008, determina expressamente em seu artigo $6^{\circ}$, inciso III, que o relatório elaborado a partir das investigações conduzidas no âmbito de inquérito administrativo deverá apresentar, entre outros elementos, "a análise de autoria das infrações apuradas, contendo a individualização da conduta dos acusados, fazendo-se remissão expressa às provas que demonstrem sua participação nas infrações apuradas".

\footnotetext{
${ }^{122}$ SANTOS, Alexandre Pinheiro dos; OSÓRIO, Fábio Medina; WELLISCH, Julya Sotto Mayor. Op. Cit., pp. 72-73.Vide também EIZIRIK, Nelson. Responsabilidade Civil e Administrativa (...), pp. 59-60.

${ }^{23}$ CARVAlHOSA, Modesto. Op. Cit., pp. 40-41.

${ }^{124}$ EIZIRIK, Nelson. Responsabilidade Civil e Administrativa (...). p. 59.
} 
Acrescenta-se, ainda, que o princípio da incomunicabilidade da culpa não se aplica somente na fase de reconhecimento da responsabilidade do administrador, de modo que, em se tratando de ato ilícito praticado por vários administradores em conjunto (via decisão colegiada ou não), a dosimetria da penalidade a ser imposta a cada um deles também deverá considerar a participação individual no evento ilegal.

Cumpre ainda destacar a aplicação da business judgment rule no âmbito da CVM, cujos precedentes revelam a recepção desta regra pela esfera administrativa e a evolução da autarquia na segmentação e delimitação dos elementos que a compõem ${ }^{125}$.

Em linhas gerais, verifica-se que, no que diz respeito a decisões tomadas dentro do limite de discricionariedade conferido ao administrador por força da lei e do estatuto social ${ }^{126}$, a CVM vem adotando a business judgement rule como padrão de revisão (standard of review), a partir do qual se entende que, observados certos cuidados durante o processo decisório, não caberá ao julgador avaliar a conveniência e a oportunidade da decisão tomada.

Ressalta-se, ainda, que, a partir da manifestação de voto do Diretor Pedro Oliva Marcilio no julgamento do Processo Administrativo Sancionador CVM n ${ }^{\circ}$ RJ2005/1443, consolidou-se o entendimento de que a business judgment rule se aplica às decisões (i) informadas; (ii) refletidas; e (iii) desinteressadas.

125 PAS CVM n ${ }^{\circ}$ 03/02, Rel. Norma Jonssen Parente, j. em 12.02.2004; PAS CVM no RJ2005/1443, Rel. Pedro Oliva Marcilio, j. em 10.05.2006; PAS CVM nº 08/05, Rel. Eli Loria, j. em 12.12.2007; PAS CVM no 21/04, Rel. Pedro Oliva Marcilio, j. em 15.05.2007; PAS CVM RJ2007/4776, Rel. Eli Loria, j. em 12.03.2008; PAS CVM nº RJ2008/9574, Rel. Ana Novaes, j. em 27.11.2012; e PAS CVM nº 09/2006, Rel. Ana Novaes, j. em 05.03.2013.

${ }^{126}$ Quanto ao conceito de decisão negocial, ao analisar os precedentes da CVM sobre o tema e identificar as situações em que esta autarquia entender ser o caso de aplicação da business judgment rule, Pedro Henrique Castello Brigagão concluiu que "[p]ortanto, diante dessas considerações, toda e qualquer decisão tomada dentro da discricionariedade conferida aos administradores, seja direcionada ao âmbito interno da companhia, seja direcionada ao seu âmbito externo, deve ser considerada negocial e, consequentemente, analisada conforme os preceitos da business judgment rule”. BRIGAGÃO, Pedro Henrique Castello. A administração de companhias e a business judgment rule. São Paulo: Quartier Latin, 2017. p. 202. 
Deste modo, não havendo determinação legal ou estatutária orientando a atuação do administrador, pressupõe-se que este agiu dentro da esfera de discricionariedade a ele assegurada, razão pela qual goza da presunção conferida pela business judgment rule, cabendo ao titular da pretensão acusatória - no caso da CVM as superintendências responsáveis pela condução do inquérito administrativo - o ônus de provar que o administrador agiu de má-fé, com falta de diligência ou desrespeito aos interesses sociais $^{127}$.

Da análise dos precedentes da CVM envolvendo a aplicação da business judgment rule, nota-se que boa parte envolve a apreciação da conduta do administrador à luz do dever de diligência previsto no artigo 153 da Lei das S.A. Isso porque, tal como exposto no item 2.1.1. acima, a própria avaliação da culpa do administrador confunde-se com a verificação da observância do standard geral de diligência fixado na legislação societária.

\subsubsection{2. $\quad O$ papel da CVM na regulação do mercado de valores mobiliários}

O papel desempenhado pela CVM na regulação e no desenvolvimento do mercado de valores mobiliários pode ser exercido por meio de suas competências normativa, fiscalizadora e reguladora.

Conforme adiantado no item 2.1.2 acima, a CVM, na qualidade de entidade autárquica responsável pela fiscalização das companhias abertas, tem competência para apreciar a responsabilidade de administrador de companhia aberta decorrente de violação da Lei das S.A. e da legislação do mercado de capitais.

Esclareça-se, ainda, que, por força do exercício da competência normativa da CVM, os administradores estão sujeitos não somente às normas previstas na Lei das S.A. e na legislação do mercado de capitais,

${ }^{127}$ Ibidem, pp. 119-120. 
como também às regras dispostas nos atos normativos editados por esta autarquia, em observância ao disposto no artigo $8^{\circ}$, inciso I, da Lei ${ }^{\circ}$ $6.385 / 76$.

De modo a assegurar a eficácia da atuação fiscalizadora da CVM, atribui-se a esta autarquia a competência para impor as seguintes penalidades ao infrator: (i) advertência; (ii) multa pecuniária; (iii) inabilitação temporária para o exercício do cargo de administrador ou de conselheiro fiscal de companhia aberta ou de outras entidades que dependam da autorização ou registro na CVM; (iv) suspensão da autorização ou registro ou inabilitação temporária para o exercício das atividades de que trata a Lei $\mathrm{n}^{\circ}$ 6.385/76; (v) proibição temporária de praticar determinadas atividades ou operações para os integrantes do sistema de distribuição ou de outras entidades que dependam de autorização ou registro na CVM; ou (vi) proibição temporária de atuar, direta ou indiretamente, em uma ou mais modalidades de operação no mercado de valores mobiliários.

No que diz respeito à multa pecuniária a ser aplicada pela CVM em processos administrativos sancionadores, destaca-se que a Lei $n^{\circ} 6.385 / 76$ prevê que o montante a ser fixado a partir da dosimetria da pena não poderá exceder o maior dos seguintes critérios: (i) $\mathrm{R} \$ 500.000,00$; (ii) cinquenta por cento do valor da emissão ou operação irregular; ou (iii) três vezes o montante da vantagem econômica obtida ou da perda evitada em decorrência do ilícito, nos termos do artigo $11, \S 1^{\circ}$ do referido diploma legal. No entanto, nos casos de reincidência, a multa poderá chegar ao triplo do valor máximo da multa considerando um destes três critérios, conforme $\S 2^{\circ}$ deste mesmo dispositivo.

Ademais, vale ressaltar que, em $1^{\circ}$ de novembro de 2017, foi submetido à sanção presidencial o Projeto de Lei da Câmara nº 129/2017 (antes Lei n ${ }^{\circ}$ 8843/2017) prevendo a alteração de normas referentes ao processo 
administrativo sancionador conduzido tanto pelo Banco Central quanto pela $\mathrm{CVM}^{128}$.

Entre as alterações propostas, inclui-se um aumento significativo no teto máximo para esta penalidade, que saltaria de $\mathrm{R} \$ 500.000,00$ (quinhentos mil reais) para $\mathrm{R} \$ 50.000 .000,00$ (cinquenta milhões de reais), nos termos do artigo $11, \S 1^{\circ}$, inciso I do referido diploma legal. Além disso, incluir-se-ia a possibilidade de a multa ser fixada pelo dobro do prejuízo causado aos investidores, mediante a inclusão do inciso IV, do $\S 1^{\circ}$ do artigo 11 da Lei $n^{\circ} 6.385 / 76$.

Entre as penalidades passíveis de aplicação a administradores de companhias abertas, a mais grave seria a inabilitação temporária para o exercício de cargo de administrador ou de conselheiro fiscal de companhia aberta, cujo período máximo de afastamento é de até vinte anos. Esta penalidade, tal como aquelas indicadas nos itens (iv) a (vi) do parágrafo anterior, só poderá ser aplicada nos casos de infração grave, conforme definidos em normas próprias da CVM.

Ainda assim, considerando que o interesse legítimo objeto de garantia pelo seguro de responsabilidade civil de administradores é o patrimônio do administrador, apresenta maior relevância para o presente trabalho a possibilidade de imposição de multa pecuniária, cuja cobertura pelo seguro D\&O foi objeto de controvérsia até a edição da Circular SUSEP $n^{\circ}$ 541/2016, conforme detalhadamente exposto no capítulo 3 adiante.

O valor das multas pecuniárias, acrescido dos honorários advocatícios despendidos para a defesa ao longo de todo o procedimento administrativo, representa pesado ônus ao patrimônio dos administradores. Deste modo, a

\footnotetext{
${ }^{128}$ De acordo com a tramitação informada no website do Senado Federal, em $1^{\circ}$ de novembro de 2017, o Projeto de Lei da Câmara no 129/2017 foi submetido à sanção presidencial. Disponível em $\langle$ http://www25.senado.leg.br/web/atividade/materias/-/materia/131318>. Acessado em $03 \mathrm{de}$ novembro de 2017. Ressalta-se, ainda, que o referido projeto de lei aproveita em parte o conteúdo da Medida Provisória no 784 editada em 07 de junho de 2017, mas que perdeu a sua vigência em 19 de outubro de 2017.
} 
alteração indicada no Projeto de Lei da Câmara no 129/2017, propõe um significativo aumento no potencial de impacto de tais multas.

\subsubsection{3. $\quad$ O termo de compromisso no âmbito da CVM}

A Lei n 9.457, de 05 de maio de 1997 (“Lei n 9.457/97”) introduziu no regime legal da Lei $\mathrm{n}^{\mathrm{o}} 6.385 / 76$, especificamente em seu artigo $11, \S 5^{\circ}$, a possibilidade de celebração de instrumento consensual de ajuste de conduta entre a CVM e o investigado, o qual importará a suspensão do procedimento administrativo até a verificação do cumprimento das obrigações eventualmente assumidas.

Além de promover a resolução antecipada e eficiente de procedimentos administrativos, evitando vicissitudes inerentes a procedimentos de caráter punitivo $^{129}$, e representar uma economia de tempo para a entidade reguladora, o termo de compromisso possibilita a obtenção de resultados que não seriam alcançados por meio da imposição de penalidades em eventual condenação no processo administrativo sancionador, tal como o ressarcimento dos prejuízos causados em razão da conduta ilícita do acusado.

Isso porque o próprio $§ 5^{\circ}$ do artigo 11 da Lei $n^{\circ} 6.385 / 76$ prevê como condições para a celebração do termo de compromisso: (a) a interrupção da prática das atividades ou atos ilícitos objeto de investigação pela CVM; e (b) a correção das irregularidades apontadas, inclusive mediante a indenização dos danos causados.

Como exposto no item 2.1.2 acima, a atuação administrativa sancionadora não tem por objetivo a composição de prejuízos causados a terceiros ou a tutela de interesses particulares da vítima do ato ilícito

\footnotetext{
${ }^{129}$ Nesse sentido, convém ressaltar os desafios enfrentados em procedimentos administrativos no que diz respeito à matéria probatória. Alexandre Pinheiro dos Santos ressalta que "Por derradeiro, cabe ainda mencionar as evidentes dificuldades estatais relacionadas com o tema da prova, especialmente quando se está diante da necessidade de comprovar o consentimento de um ilícito com a utilização, preponderantemente, de prova indiciária (caso, por exemplo, do insider trading)". SANTOS, Alexandre Pinheiro dos. Por que defender os termos de compromisso no mercado de capitais?. Espaço Jurídico BM\&FBOVESPA, jan. 2010. p. 04.
} 
praticado no mercado de valores mobiliários, razão pela qual a sanção administrativa revela um caráter disciplinar, voltado a desestimular a prática de ilícitos pelo próprio infrator e por outros participantes do mercado.

Desse modo, ainda que se conclua pela responsabilização dos acusados, a penalidade a eles imposta não assegurará o ressarcimento dos danos causados aos sujeitos lesados por sua conduta ou, mesmo, ao mercado, em observância aos interesses difusos e coletivos tutelados pela CVM. O termo de compromisso, por sua vez, traz essa possibilidade à entidade reguladora.

Além disso, podem ser negociadas outras obrigações junto ao investigado que assegurem com maior efetividade o restabelecimento do status quo existente antes da prática da conduta supostamente ilícita ${ }^{130}$.

Apresentados os principais benefícios da celebração de termos de compromisso no âmbito dos procedimentos administrativos conduzidos pela CVM, ressalta-se que, em vista do objeto do presente trabalho, não convém esmiuçar o trâmite que deverá ser observado para a celebração do termo de compromisso.

Para o tema do presente trabalho, cabe salientar que, na esfera administrativa, o termo de compromisso representa outra fonte de obrigações ao administrador, por meio da qual impõe-se o dever de ressarcir prejuízos sofridos diretamente por um ou mais investidores, passíveis de quantificação a partir dos elementos constantes do procedimento investigatório, ou, ainda, o dever de recomposição de danos

${ }^{130}$ Como exemplo de obrigações mais efetivas obtidas por meio da celebração de termo de compromisso, convém mencionar a proposta apresentada no âmbito do Processo Administrativo Sancionador CVM n ${ }^{\circ}$ RJ2016/8896, nos termos da qual os proponentes, acusados de terem violado o artigo 155, inciso I, da Lei das S.A., por terem supostamente usado em benefício próprio oportunidade comercial de interesse da Companhia, comprometeram-se a transferir, a título gratuito, todas as ações de emissão da sociedade constituída no Paraguai, em suposta usurpação da oportunidade comercial, à Companhia, sem prejuízo do valor pecuniário a ser pago à CVM. Tal proposta foi apreciada em reunião do Colegiado de 26 de setembro de 2017, que, não obstante o parecer do Comitê de Termo de Compromisso pela rejeição da proposta, entendeu que os efeitos da obrigação não pecuniária indicariam a conveniência da celebração do termo de compromisso. Condicionaram, no entanto, a aceitação da proposta ao ajuste da forma de pagamento da obrigação pecuniária. 
causados aos interesses difusos ou coletivos no âmbito do mercado de capitais.

De uma forma ou de outra, trata-se de obrigação pecuniária, de modo que se questiona acerca da possibilidade de cobertura destes valores pelo seguro de responsabilidade civil de administradores, conforme será exposto no capítulo 3 deste trabalho.

Cumpre ressaltar, no entanto, que o termo de compromisso conta com uma característica fundamental: tal instrumento não importa confissão quanto à matéria de fato, nem reconhecimento de ilicitude da conduta analisada, nos termos expressamente previstos no artigo $11, \S 6^{\circ}$ da Lei $n^{\circ}$ 6.385/76 e no artigo $4^{\circ}$ da Deliberação CVM nº 390/01.

\subsubsection{Responsabilidade Penal}

Conforme ressaltado por Clara Beatriz Lourenço de Faria ${ }^{131}$, em razão da gravidade de determinados atos praticados na gestão social e da intenção do legislador de coibir de forma mais efetiva estas condutas, busca-se não apenas a responsabilização do administrador em âmbito cível, como também na esfera criminal.

No que diz respeito à sua natureza, o direito penal brasileiro consagra a responsabilidade subjetiva e personalíssima daqueles que concorram por qualquer meio para a prática delituosa, de modo que se extraem as seguintes conclusões: (i) a responsabilidade penal depende da demonstração de elemento subjetivo; e (ii) ninguém poderá ser responsável criminalmente por atos de outrem.

Não poderia ser diferente no caso de administradores de companhias abertas, de modo que a sua responsabilidade na esfera penal pressupõe a prova da efetiva participação na consecução do ilícito penal, em observância ao princípio da culpabilidade.

${ }^{131}$ FARIA, Clara Beatriz Lourenço de Faria. O seguro D\&O e a proteção ao patrimônio dos administradores. $2^{\text {a }}$ Ed. São Paulo: Almedina, 2015. p. 37. 
As hipóteses de responsabilização criminal do administrador estão previstas no Decreto-Lei $\mathrm{n}^{\circ}$ 2.848, de 7 de dezembro de 1940 (“Código Penal"), bem como na legislação esparsa que tratam de matérias específicas (crimes contra a ordem tributária, falimentares, ambientais, contra a ordem econômica, etc.) ${ }^{132}$.

No Código Penal, sob o título "Fraudes e abusos na fundação ou administração de sociedade por ações”, os ilícitos penais imputados ao administrador estão previstos nos incisos do $\S 1^{\circ}$ do artigo 177 . O próprio título deste dispositivo revela que a sua aplicação se restringe às condutas verificadas no âmbito de sociedades anônimas. Verifica-se, inclusive, que algumas hipóteses descritas neste artigo, tal como os incisos III, VI e VII, refletem disposições da Lei das S.A., especialmente regras de vedação de conduta impostas ao administrador.

Pela prática dos crimes descritos no artigo $177, \S 1^{\circ}$ do Código Penal atribui-se pena de reclusão de um a quatro anos e multa. Ressalta-se que tais ilícitos penais não admitem a modalidade culposa, sendo necessário o dolo do agente ${ }^{133}$.

Observado esse regime geral de responsabilidade penal do administrador no âmbito do Código Penal, vale ressaltar a crítica apresentada por Hugo de Brito Machado, segundo o qual:

"[n] ão são raras, porém, as manifestações na doutrina e na jurisprudência que, por via oblíqua, em se tratando de crimes ocorridos no âmbito de empresas, adotam a responsabilidade penal objetiva, ou, ainda, o que é mais grave, adotam a responsabilidade penal por fato de outrem" $"$.

Tal afirmação procura rebater algumas interpretações jurisprudenciais adotadas especialmente em crimes contra o meio ambiente ou contra a ordem tributária nacional, em que tem se buscado na esfera criminal uma

\footnotetext{
132 Ibidem, p. 37.

133 Ibidem, p. 40.

134 MACHADO, Hugo de Brito. Responsabilidade Penal no Âmbito das Empresas. In: Direito Penal Empresarial. Org. SALOMÃO, Heloisa Estellita. São Paulo: Dialética, 2001. p. 121.
} 
forma de sancionar com maior gravidade as condutas ilícitas praticadas no âmbito da pessoa jurídica.

Nestes casos, o autor argumenta que, muito embora o artigo 41 do Código Penal determine que a denúncia deverá conter, entre outros elementos, a indicação específica da conduta individual de quem supostamente tenha participado da prática delituosa, em alguns casos verifica-se a apresentação de denúncias genéricas relativas a ilícitos cometidos no âmbito da pessoa jurídica, dispensando a descrição individualizada da conduta, de forma que a imputação de determinado ilícito ao administrador decorreria tão somente da posição por ele ocupada na administração da companhia. É justamente contra esse entendimento que o autor procura se insurgir ${ }^{135}$.

Por estas razões, Hugo de Brito Machado reitera que:

"A responsabilidade penal não pode decorrer do fato do exercício da administração da empresa. (...) Não basta, porém, que o acusado seja de fato diretor. É preciso que tenha praticado a conduta que o coloca na condição de autor, ou de partícipe, no crime. Em outras palavras, a responsabilidade penal depende sempre da conduta pessoal, que há de configurar autoria ou participação" 136.

Em síntese, tem-se que, com base nos princípios gerais do direito penal, notadamente o princípio da culpabilidade, as hipóteses de responsabilização criminal do administrador estão vinculadas à demonstração de culpa lato sensu. Contudo, em se tratando de crimes contra o meio ambiente ou contra a ordem tributária, é possível identificar manifestações jurisprudenciais em sentido diverso.

\footnotetext{
${ }^{135}$ Ibidem, p. 122-123.

${ }^{136}$ Ibidem, p. 125.
} 


\section{CAPÍTULO 3 - O SEGURO D\&O E A REGULAMENTAÇÃO DA SUSEP}

\subsection{A relevância do seguro $D \& O$ como instrumento de tutela de múltiplos interesses}

Os desafios que a condução dos negócios sociais impõe aos administradores associados à expectativa dos acionistas de maximização dos lucros e desenvolvimento das atividades sociais muitas vezes leva estes profissionais a tomarem decisões arriscadas, que podem acarretar prejuízos aos acionistas, à companhia ou a terceiros que com ela se relacionem.

Deste modo, tal como exposto no capítulo anterior, o administrador pode ser chamado a responder por sua conduta na gestão da companhia, seja para fins de reparação dos prejuízos causados, seja em caráter disciplinar.

Muito embora o regime legal de responsabilidade desempenhe papel fundamental na prevenção de danos e na adequação da conduta do administrador às normas legais, também representa um severo ônus ao seu patrimônio, que deverá suportar os custos de defesa e fazer frente ao montante das indenizações ou multas pecuniárias fixadas em caso de condenação.

Por esta razão, os riscos aos quais estão expostos os administradores em razão das funções exercidas na gestão social podem representar um obstáculo às companhias na contratação de profissionais capacitados, ou, ainda, incentivar uma gestão excessivamente conservadora, que, muito provavelmente, não atenderá os interesses sociais.

Soma-se a isso o fato de que a exposição dos administradores é cada vez maior, haja vista as inúmeras áreas do direito em que se admite a responsabilização pessoal do administrador, como exposto acima, bem 
como a interpretação ampliativa que se tem conferido ao instituto da desconsideração da personalidade jurídica ${ }^{137}$.

Diante disso, o patrimônio pessoal do administrador pode ser insuficiente para suportar todos os custos decorrentes das ações judiciais ou procedimentos administrativos movidos para a sua responsabilização, bem como para reparar os prejuízos causados a partir dos atos praticados na administração da companhia.

Há, portanto, uma grande chance de que, mesmo reconhecida a responsabilidade do administrador, este último não disponha de recursos suficientes para assegurar a recomposição dos danos sofridos pelo sujeito lesado.

Nesse sentido, Ernesto Tzirulnik esclarece que:

"o ponto de estagnação da responsabilidade civil, mesmo considerando os rombos havidos na sua concepção clássica, não será outro senão a incapacidade de todo e qualquer instituto jurídico de promover a reparação econômica, especialmente no mundo contemporâneo, na chamada "civilização do risco", que, sem embargo das crescentes técnicas e políticas de prevenção, produz até mesmo danos que jamais os patrimônios individuais seriam capazes de suportar “138.

Verifica-se, portanto, uma intensificação dos riscos, que "perderam, na sociedade contemporânea, o seu caráter acidental e fatalístico, convertendo-se em prejuízos que acompanham, necessariamente, o desenvolvimento de certas atividades socialmente úteis (...)" $139 \mathrm{e}$, por conseguinte, uma ampliação dos danos a serem ressarcidos, sem que houvesse, em contrapartida, um aumento do poder de reparação dos agentes econômicos responsáveis pelos negócios sociais.

Se forem considerados ainda os entraves existentes para a propositura de ação de responsabilidade em face do administrador, tais como os custos da ação, as despesas de sucumbência, a dificuldade em demonstrar a culpa

\footnotetext{
${ }^{137}$ Vide nota de rodapé $\mathrm{n}^{\circ} 68$.

${ }^{138}$ TZIRULNIK, Ernesto. Op. Cit. p. 718.

${ }^{139}$ SCHREIBER, Anderson. Novos paradigmas da responsabilidade civil: da erosão dos filtros da reparação à diluição dos danos. $5^{\mathrm{a}}$ ed. São Paulo, Atlas, 2013. p. 232.
} 
ou dolo do administrador e, em especial nos casos de ação social $u t$ universi, a dificuldade de atingir o quórum de deliberação para aprovação da matéria, nota-se que são muito reduzidos os incentivos para que o sujeito lesado busque a reparação de seus danos.

O estímulo para propositura da ação é ainda menor se a perspectiva de ressarcimento depende da solvabilidade do patrimônio pessoal do administrador.

Conforme ressaltado por Ana Carolina Rodrigues, "[a] ideia de risco do investimento acionário se torna anda mais patente quando notamos que nem o sucesso em uma ação de responsabilidade civil é capaz de garantir o ressarcimento dos danos sofridos" 140.

Levando em conta estes elementos e os diversos interesses envolvidos, o seguro de responsabilidade civil de administradores desponta como a técnica privada mais adequada para conciliar tais interesses, assegurando não apenas o interesse legítimo do administrador de ver o seu patrimônio pessoal resguardado de eventual efeito econômico negativo decorrente de sua responsabilização por ato de gestão, como também o interesse do sujeito lesado de recompor os prejuízos sofridos e evitar a sua permanência em estado de dano.

O seguro de responsabilidade civil de administradores atende igualmente os interesses da companhia, que, na maioria das vezes, figura como tomadora do seguro, respondendo perante a seguradora pelas condições de contratação, inclusive, o pagamento do prêmio.

Ao contratar o seguro D\&O, normalmente por meio de apólice coletiva que assegura a garantia de todos os administradores, adequando-se à rotatividade de profissionais nos órgãos da administração, a companhia atende às preocupações de seus gestores, facilitando a atração de

\footnotetext{
${ }^{140}$ RODRIGUES, Ana Carolina. A responsabilidade civil e o Seguro D\&O. In: Revista de Direito Bancário e do Mercado de Capitais. São Paulo, vol. 58, out.-dez. 2012, p. 440.
} 
profissionais qualificados, e, ao mesmo tempo, a depender da cobertura contratada, assegura a proteção do seu próprio patrimônio.

Isso porque, tal como descrito no capítulo anterior, em determinadas situações, a companhia é chamada a responder solidariamente pelos prejuízos causados pelo administrador na gestão social ${ }^{141}$.

Além disso, caso a companhia venha a assegurar a indenidade de seus administradores, seja por meio da celebração de instrumento particular, seja por meio de cláusula estatutária nesse sentido, poderá ter que suportar os custos de defesa ou, até mesmo, as indenizações atribuídas ao administrador. Neste cenário, o seguro D\&O poderá oferecer o reembolso destas despesas à companhia tomadora, conforme será analisado mais detalhadamente à frente.

Ressalta-se, ainda, que, tal como os demais sujeitos lesados, a companhia poderá beneficiar-se do seguro como destinatária da indenização devida pelo administrador em caso de prejuízos causados ao patrimônio social em decorrência de sua atuação na gestão social.

Conclui-se, portanto, que o seguro de responsabilidade civil de administradores garante não apenas o interesse legítimo do administrador de resguardar o seu patrimônio pessoal, como também os interesses da companhia e dos demais sujeitos lesados por eventual conduta danosa do administrador na condução dos negócios sociais.

Apresentado o conceito geral do seguro de responsabilidade civil de administradores e revelados os diferentes interesses que são tutelados por esta modalidade de seguro, passa-se a analisar as suas características particulares a partir da regulamentação recente editada pela SUSEP.

\footnotetext{
141 Tal como exposto anteriormente, é possível ainda que a companhia venha a responder solidariamente mesmos nos casos em que o administrador atue em violação à lei ou ao estatuto social, nas hipóteses em que o prejudicado for terceiro de boa-fé ou, ainda, quando a companhia houver ratificado o ato ou tirado proveito de seus efeitos.
} 


\subsection{Intervenção do Estado na atividade securitária: o papel da SUSEP}

$\mathrm{O}$ ordenamento jurídico brasileiro trata do seguro tanto sob a perspectiva contratual, nos termos dos artigos 757 a 802 Código Civil, conforme abordado no item 1.3 acima, quanto em seu caráter sistêmico, no que diz respeito ao Sistema Nacional de Seguros Privados.

Sob este enfoque, pressupõe-se destacada intervenção do Estado em diferentes esferas da atividade securitária, mediante (i) a autorização prévia para operação com seguros; (ii) a fiscalização da atividades das seguradoras; (iii) a regulamentação, a priori, das condições gerais das apólices de seguro; (iv) a imposição da contratação do seguro em determinados casos (por exemplo, no caso do DPVAT); (v) a exigência de registro dos contratos de seguros celebrados; e (vi) o controle da higidez das seguradoras ${ }^{142}$.

Como adiantado, essa intervenção foi estruturada a partir da organização do Sistema Nacional de Seguros Privados, criado a partir do Decreto-Lei ${ }^{\circ}$ $73 / 1966^{143}$ e constituído, nos termos do art. $8^{\circ}$ do referido diploma legal, pelo Conselho Nacional de Seguros Privados - CNSP, pela SUSEP, pelos resseguradores, pelas seguradoras e pelos corretores habilitados ${ }^{144}$.

Considerando o objeto do presente trabalho, cumpre ressaltar a atuação do CNSP, a quem compete, em termos gerais, fixar as diretrizes e normas da política de seguros privados, as quais, por sua vez, serão executadas pela SUSEP, que atua como órgão fiscalizador da organização, funcionamento e operações das seguradoras.

Acerca das funções exercidas pela SUSEP, Amadeu Carvalhaes Ribeiro esclarece que estas são de três espécies: (i) função executiva; (ii) função fiscalizadora; e (iii) função reguladora. A função executiva diz respeito

\footnotetext{
${ }^{142}$ RIBEIRO, Amadeu Carvalhaes. Op. Cit. p. 139.

${ }^{143}$ O Decreto-Lei $n^{\circ}$ 73/1966 foi recepcionado pelo artigo 192 da Constituição Federal de 1988 com força de lei complementar e é regulamentado pelo Decreto n ${ }^{\circ} 60.459 / 1967$.

${ }^{144}$ RIBEIRO, Amadeu Carvalhaes. Op. Cit. p. 140.
} 
justamente à execução das atribuições conferidas pelo CNSP, entre as quais se destaca o processamento de pedidos de registro de novas seguradoras e de operações envolvendo a transferência de controle destas sociedades ${ }^{145}$.

Considerando o objetivo do presente trabalho de analisar a regulamentação conferida ao seguro de responsabilidade civil de administradores, ganha destaque a função reguladora.

Nesse sentido, destacam-se as seguintes competências atribuídas à autarquia no artigo 36 do Decreto Lei no 73/1966:

“(...) b) baixar instruções e expedir circulares relativas à regulamentação das operações de seguro, de acordo com as diretrizes do CNSP;

c) fixar condições de apólices, planos de operações e tarifas a serem utilizadas obrigatoriamente pelo mercado segurador nacional; (...)

e) examinar e aprovar as condições de coberturas especiais, bem como fixar as taxas aplicáveis; (...)".

No exercício destas atribuições, por meio da Circular $n^{\circ} 553$, de 28 de abril de 2016, a SUSEP estabeleceu a codificação dos ramos de seguro, entre os quais o ramo da responsabilidade civil de administradores, que, em conjunto com outras modalidades, integra o grupo de seguros de responsabilidade.

\subsection{O histórico de regulamentação do seguro $D \& O$}

Naturalmente, o histórico de regulamentação do seguro de responsabilidade civil de administradores se confunde com o próprio desenvolvimento desta modalidade de seguro no Brasil.

Nesse sentido, verifica-se que, muito embora ao final da década de 90 algumas companhias abertas que negociavam American Depositary Receipts (ADRs) ${ }^{146}$ tenham começado a contratar o seguro D\&O como

\footnotetext{
145 Ibidem, p. 143.

${ }^{146}$ Nos termos do art. $1^{\circ}$, inciso I, da Instrução CVM n ${ }^{\circ} 559$, de 27 de março de 2015, entende-se por "Depositary Receipts" "os certificados emitidos no exterior por instituição depositária, representativos dos ativos autorizados em regulamentação específica emitida pelo Conselho Monetário Nacional - CMN, depositados em custódia específica no País". No caso dos American Depositary Receipts, trata-se de títulos emitidos por instituição depositária norte americana.
} 
forma de se resguardar de eventuais ações indenizatórias propostas por investidores estrangeiros contra seus administradores ou contra a própria companhia, o desenvolvimento do mercado securitário nacional para esta espécie de seguro ganhou força após a reforma do Código Civil, que impôs um regime de responsabilidade civil mais rígido ${ }^{147}$.

Posteriormente, conforme destacado por Ana Carolina Rodrigues, a importância do seguro D\&O passou a ser reconhecida pelas companhias, tendo sido firmada, inclusive, parceria entre a Bovespa - posteriormente, BM\&FBovespa e atual, $\mathrm{B}^{3}$ - e a seguradora Unibanco AIG, oferecendo vantagens especiais às companhias listadas na bolsa que contratassem este seguro, o que teria contribuído para a difusão do seguro de responsabilidade civil de administradores ${ }^{148}$.

Esta difusão do seguro D\&O pôde ser notada não apenas no valor total dos prêmios diretos atuais, que no período de 2003 a 2010 cresceram aproximadamente $185 \%$, como também no número de contratações do seguro entre companhias abertas integrantes do índice Bovespa (Ibovespa) 149

Acompanhando o crescimento desta modalidade de seguro no mercado brasileiro, a regulamentação pátria recepcionou o seguro de responsabilidade civil de administradores como categoria geral de "seguro de responsabilidade" e o identificou como ramo "10", nos termos do Anexo I das Circulares SUSEP no 395/2009 e 535/2016.

No entanto, ainda que a SUSEP tenha determinado o enquadramento do Seguro D\&O como ramo da categoria de seguro de responsabilidade civil, não fixou, neste primeiro momento, um conjunto de regras próprias aplicáveis a esta modalidade de seguro, razão pela qual as cláusulas gerais que regiam a contratação e o funcionamento deste seguro eram aquelas

\footnotetext{
${ }^{147}$ RODRIGUES, Ana Carolina. Op. Cit., p. 446.

${ }^{148}$ Ibidem, p. 446.

${ }^{149}$ Informações extraídas do artigo de Ana Carolina Rodrigues, a partir de dados disponibilizados pela SUSEP e de estudos independentes conduzidos pela autora (Ibidem., pp. 446-447).
} 
aplicáveis às apólices à base de reclamações, entre as quais as normas previstas na Circular SUSEP n ${ }^{\circ} 336 / 2007^{150}$.

Neste período, em razão da ausência de regras específicas para o seguro D\&O, as seguradoras contavam com maior espaço para fixação das condições das apólices de seguros, observadas sempre as cláusulas gerais do seguro de responsabilidade civil à base de reclamações.

Diante disso, algumas apólices de seguro D\&O admitiam a cobertura de multas aplicadas aos administradores em função das atividades por eles exercidas na administração da companhia ${ }^{151}$.

Em 2008, a Procuradoria de Assuntos Societários e Regimes Especiais da SUSEP emitiu parecer interno segundo o qual as apólices de seguro D\&O não poderiam incluir a cobertura de multas impostas ao segurado, uma vez que a partir de tal previsão "haverá um desestímulo ao não respeito as leis ${ }{ }^{152}$, isto é, comprometeria o caráter disciplinador da multa aplicada, afastando os efeitos patrimoniais negativos decorrentes da conduta do administrador e desestimulando a adoção de práticas de governança corporativa $^{153}$.

Contudo, somente em 2012, este entendimento passou a ser adotado pela SUSEP quando da análise das apólices submetidas a registro perante esta autarquia, culminando com a negativa de diversos pedidos de renovação e celebração de seguros $\mathrm{D} \& \mathrm{O}$ com a previsão de cobertura para multas.

Esta nova orientação não foi bem recebida pelo mercado e levou alguns autores a posicionarem-se contrariamente a esta vedação. Nesse sentido,

\footnotetext{
${ }^{150}$ CARA, Marília de. Op. Cit. p. 55.

151 AMARO, Anderson de Souza. O seguro de responsabilidade civil dos administradores. In: Revista de Direito Empresarial. Belo Horizonte: vol. 2, mar.-abr. 2014, pp. 118-119.

152 Conforme "Anexo I" à Dissertação de Mestrado de Marília de Cara (CARA, Marília de. Op. Cit. p. 144-148).

${ }^{153}$ AMARO, Anderson de Souza, Op. Cit. pp. 118-119.
} 
Anderson de Souza Amaro ${ }^{154}$ argumentou que a restrição na cobertura de multas pela apólice D\&O desvirtuaria o próprio objeto do seguro, cuja contratação visa conferir maior liberdade aos administradores para que estes possam tomar decisões negociais menos convencionais sem ter que expor o seu patrimônio pessoal aos efeitos de eventual multa.

Ademais, ressaltou que o limite da legitimidade do interesse do segurado estaria expressamente previsto no artigo 757 do Código Civil com a vedação da cobertura de atos dolosos, de modo que careceria de sustentação jurídica a limitação imposta pelo parecer da SUSEP.

Conforme se verá adiante, esta orientação foi revista pela SUSEP quando da elaboração de regulamentação específica para esta modalidade de seguro.

Posteriormente, com a edição da Circular SUSEP no 437/2012, que fixou as regras básicas para a comercialização do Seguro de Responsabilidade Civil Geral, estabeleceu-se que o seguro D\&O consistiria em outro ramo do seguro, cujos riscos não estariam abarcados pela apólice de responsabilidade civil geral ${ }^{155}$.

A partir de então o mercado securitário passou a aguardar um posicionamento da SUSEP estabelecendo regras específicas para esta modalidade de seguro.

Em 10 de janeiro de 2014, a SUSEP submeteu à Consulta Pública n 26/2013 minuta de circular estabelecendo diretrizes gerais aplicáveis aos seguros de responsabilidade civil de administradores.

\footnotetext{
${ }^{154}$ AMARO, Anderson de Souza. Op. Cit., pp. 118-119.

${ }^{155} \mathrm{O}$ artigo $6^{\circ}$ da Circular SUSEP $\mathrm{n}^{\circ} 437 / 2012$ prevê o seguinte: "Art. $6^{o}$. O Seguro de Responsabilidade Civil Geral, de contratação facultativa, constitui um ramo específico, e cobre os riscos de responsabilização civil por danos causados a terceiros, abrangendo, como Segurados: I - as empresas e os produtos elou serviços a elas vinculados; II - as pessoas físicas; III - os condomínios. (...)

$\S 2^{\circ}$ Os riscos de responsabilização civil vinculados ao exercício de cargos de Direção elou Administração em empresas são enquadrados em outro ramo de seguro, denominado seguro de responsabilidade civil de diretores e administradores de empresas (RCD\&O)'”.
} 
De acordo com o conteúdo da minuta disponibilizada pela SUSEP, destacam-se os seguintes pontos: (i) não era prevista a contratação do seguro diretamente pela pessoa física, isto é, pelos administradores da sociedade; (ii) afastava-se expressamente a garantia dos custos de defesa e dos honorários advocatícios, que deveriam ser objeto de cobertura adicional específica (art. $5^{\circ}, \S 3^{\circ}$ ); e (iii) não havia previsão de cobertura de multas e penalidades cíveis e administrativas.

Cumpre ressaltar que durante o período de ausência de regulamentação específica aplicável ao seguro D\&O prevaleceu no mercado a contratação de apólices na base "all-risks", seguindo o padrão internacional para esta modalidade de seguro ${ }^{156}$. Em apólices "all-risks", delimita-se o objeto de cobertura e apresentam-se definições chaves, tais como "Ato Danoso", "Fato Gerador", "Perdas", "Pessoa Segurada" e etc., e, a partir disso, entende-se que todos os riscos que não estão explicitamente excluídos na apólice de seguro são passíveis de cobertura ${ }^{157}$.

No entanto, com o crescimento do mercado, a criação de normas prevendo novas esferas de responsabilização de administradores, tal como é o caso da Lei Anticorrupção, o fortalecimento das teorias da desconsideração da personalidade jurídica, em especial na justiça do trabalho, e o desenvolvimento das companhias seguradas, passou-se a questionar a extensão da cobertura do seguro D\&O e a capacidade do mercado securitário de lidar com as novas demandas, o que contribuiu para a iniciativa da SUSEP de regulamentar esta modalidade de seguro ${ }^{158}$.

\footnotetext{
156 “The D\&O (Directors' \& Officers') insurance also provides ample protection. An open cover policy exists: everything is covered except for what has been excluded". (WETERINGS, Wim. Directors' \& Officers' liability, D\&O insurance and moral hazard: more control of moral hazard by $D \& O$ insurers needed to increase the incentives of directors and supervisory board members, 2012. p. 2 Disponível em: http://ssrn.com/abstract=2153129. Acessado em: 04 de outubro de 2017)

${ }^{157}$ Conforme ressaltado por Gustavo Galrão em reunião realizada pela Abrasca e FenSeg em 17 de novembro de 2016. (ABRASCA. Abrasca e FenSeg debatem Circular 541 da SUSEP que regula seguros RC e D\&O. In: Sistema de Informação Abrasca às Companhias Abertas - SIA \& CIA. Edição semanal. Número 1331. 10 p. 12/12/2016. Disponível em: <http://www.abrasca.org.br/Upl oads/siacia/1385_Sia_Cia_1331.pdf $>$. Acesso em: 10 de outubro de 2017).

${ }^{158}$ Ibidem.
} 
Conforme ressaltado por Henrique Vargas Beloch, mais recentemente, a explosão das denúncias da Operação Lava-Jato e o consequente aumento da sinistralidade trouxeram maior consciência da exposição dos administradores aos riscos de uma economia em baixa e elevaram os investimentos em políticas de compliance ${ }^{159}$, concorrendo para acelerar o processo de regulamentação do seguro D\&O.

Nessa esteira, em 17 de outubro de 2016, foi publicada a Circular SUSEP n ${ }^{\circ} 541 / 2016$, estabelecendo as cláusulas gerais aplicáveis ao seguro de responsabilidade civil de administradores.

Dentre as condições previstas na minuta preliminar e destacadas acima, a Circular SUSEP n 541/2016 manteve a impossibilidade de contratação do seguro por pessoa física e a exigência de cobertura adicional para os custos de defesa e honorários advocatícios. Contudo, foi incluída previsão expressa quanto à possibilidade de cobertura de multas e penalidades cíveis e administrativas impostas ao segurado quando do exercício de suas funções.

Muito embora seja positiva a pacificação da controvérsia quanto à garantia de multas e penalidades aplicadas aos administradores, ao retirar da cobertura básica do seguro $\mathrm{D} \& \mathrm{O}$ os custos de defesa e honorários advocatícios, que passaria a depender da contratação de cobertura adicional, entendeu-se que a nova norma contribuiria para esvaziar o seguro de responsabilidade civil de administradores ${ }^{160}$.

Nesse sentido, identificou-se que cerca de $90 \%$ do uso desta modalidade de seguro seria justamente a cobertura dos custos envolvendo a defesa do

\footnotetext{
${ }^{159}$ Conforme ressaltado pelo advogado Henrique Vargas Beloch em entrevista concedida ao Jornal Valor Econômico, divulgada em 21 de março de 2017 sob o título "Lava-Jato provoca mudanças no $D \& O$ ”. Disponível em: http://www.bmalaw.com.br/arquivos/Artigos/HENERIQUE LavaJato\%20provoca\%20mudan\%C3\%A7as\%20no\%20DO.pdf . Acessado em 10 de outubro de 2017. ${ }^{160}$ BUENO, Denise. Lava-Jato provoca mudanças no D\&O. In: Valor Econômico. Edição 21 de março de 2017 Disponível em: http://www.bmalaw.com.br/arquivos/Artigos/HENERIQUE_LavaJato\%20provoca\%20mudan\%C3\%A7as\%20no\%20DO.pdf. Acesso em: 08 de novembro de 2017.
} 
administrador $^{161}$. Portanto, esta mudança influenciaria diretamente na precificação deste seguro.

Da mesma forma, em reunião realizada para discutir a Circular SUSEP $n^{\circ}$ 541/2016, Gustavo Galrão, representante da Federação Nacional de Seguros Gerais - FenSeg e superintendente de Financial Lines \& Liability do ArgoGroup, ressaltou que a impossibilidade de contratação do seguro por pessoa física restringiria:

"o direito de executivos de contratar seguro de forma independente da decisão da Sociedade ou até mesmo de complementar sua cobertura ou adequá-la à sua realidade, por exemplo no caso de sociedades que contratam o seguro no exterior com restrições legais à nacionalização da indenização no país" ${ }^{162}$.

Acrescenta-se, ainda, que a referida Circular vedou a referência a qualquer tipo de legislação estrangeira, nos termos do seu artigo 12, caput $^{163}$, o que impactaria diretamente as companhias com operações fora do Brasil, e aquelas cujos valores mobiliários são negociados em bolsa de valores de outros países por meio da emissão de Depositary Receipts, posto que, para essas companhias, os riscos mais significativos são justamente aqueles decorrentes de demandas ajuizadas com base na legislação internacional $^{164}$.

Considerando que, conforme exposto inicialmente, tais companhias tiveram um papel fundamental para o início e desenvolvimento do mercado nacional do seguro D\&O, e ainda representam grande parte da demanda

\footnotetext{
161 Ibidem.

162 Manifestação de Gustavo Galrão, representante da Federação Nacional de Seguros Gerais FenSeg e superintendente de Financial Lines \& Liability do ArgoGroup, em reunião organizada pela Abrasca, com a colaboração do associado BMA Advogados, em 17 de novembro de 2016, para debater a Circular SUSEP n ${ }^{\circ}$ 541/2016, conforme ata divulgada na edição semanal do sistema de informação Abrasca às Companhias Abertas nº 1331, de 12 de dezembro de 2016. Disponível em http://www.abrasca.org.br/Uploads/siacia/1385_Sia_Cia_1331.pdf. Acessado em 10 de outubro de 2017.

163 “Art. 12. São vedadas referências a qualquer tipo de legislação estrangeira.

Parágrafo único. É permitido o uso de expressões estrangeiras relativas ao seguro de $R C D \& O$, quando já habitualmente empregadas no mercado segurador brasileiro, desde que traduzidas localmente ou cuja tradução conste do glossário do seguro".

164 ABRASCA. Abrasca e FenSeg debatem Circular 541 da SUSEP que regula seguros RC e D\&O. In: Sistema de Informação Abrasca às Companhias Abertas - SIA \& CIA. Edição semanal. Número 1331. 10 p. 12/12/2016. Disponível em: http://www.abrasca.org.br/Uploads/siacia/1385 Sia_Cia_1331.pdf. Acesso em: 10 de outubro de 2017.
} 
interna por esta modalidade de seguro, a alteração nesta regra pode reduzir consideravelmente o mercado nacional do seguro D\&O.

Outro ponto de impacto levantado seria a omissão da Circular SUSEP n ${ }^{\circ}$ 541/2016 quanto à cobertura C ("Entity Coverage”), isto é, a contratação do seguro tendo a sociedade como pessoa segurada para os casos de demandas no mercado de capitais ${ }^{165}$.

Além de contrariar a prática de mercado adotada até então, o afastamento dessa cobertura no seguro $\mathrm{D} \& \mathrm{O}$ aumentaria a exposição da companhia e de seus acionistas, que passariam a sujeitar-se a perdas patrimoniais consideráveis em caso de condenações em ações indenizatórias movidas contra a companhia ${ }^{166}$.

Soma-se a isso o fato de que as seguradoras nacionais perderiam espaço no seguro D\&O, uma vez que, impossibilitada a contratação desta cobertura específica no mercado nacional, autorizar-se-ia as companhias brasileiras a contratarem essa garantia no exterior, por força do artigo 20, inciso I, da Lei Complementar $n^{\text {o }} 126 / 2007^{167}$, o que, somado a impossibilidade de referência a legislações estrangeiras na apólice do seguro, importaria em forte impacto ao mercado nacional.

Logo após a edição da Circular SUSEP no 541/2016, em razão das intensas críticas levantadas pelo mercado, foi publicada em 24 de fevereiro de 2017 a Circular SUSEP n546/2017, que suspendeu os efeitos daquele normativo por um período de 90 dias.

\footnotetext{
165 Ao definir em seu artigo $3^{\circ}$, incisos XXX e XXXI, os conceitos de "Segurado" e "Segurado (por extensão de cobertura)", a Circular n ${ }^{\circ}$ 541/2016 não faz qualquer menção à pessoa jurídica. O mesmo se entende da redação do artigo $4^{\circ}$ e do artigo $7^{\circ}$, inciso II.

166 ABRASCA. Abrasca e FenSeg debatem Circular 541 da SUSEP que regula seguros RC e D\&O. In: Sistema de Informação Abrasca às Companhias Abertas - SIA \& CIA. Edição semanal. Número 1331. 10 p. 12/12/2016. Disponível em: http://www.abrasca.org.br/Uploads/siacia/1385 Sia_Cia_1331.pdf. Acesso em: 10 de outubro de 2017.

167 “Art. 20. A contratação de seguros no exterior por pessoas naturais residentes no País ou por pessoas jurídicas domiciliadas no território nacional é restrita às seguintes situações: I cobertura de riscos para os quais não exista oferta de seguro no País, desde que sua contratação não represente infração à legislação vigente; (...)"
} 
Estabelecidos novos diálogos entre o mercado e o ente regulador, com destaque para a atuação conjunta de diversas entidades, tais como a Associação Brasileira de Gerência e Riscos - ABGR, a Comissão de Seguros da OAB/SP, a Federação de Empresas de Resseguros FENABER, a CVM, a FenSeg e a AIDA ${ }^{168}$, antes de findo o prazo de 90 dias de suspensão da norma, foi editada a Circular SUSEP n ${ }^{\circ}$ 553/2017, cujo conteúdo será objeto de análise no item 3.4. seguinte.

\subsection{O regime regulatório da Circular SUSEP no 553/2017}

Em termos gerais, a Circular SUSEP no 553/2017 atendeu a algumas preocupações e críticas levantadas pelos participantes do mercado à regulamentação anterior, em especial no que diz respeito à extensão da cobertura securitária e à possibilidade de contratação do seguro D\&O diretamente pelo administrador, bem como aprimorou algumas regras já previstas na Circular SUSEP n⿳0 541/2016.

No entanto, ainda que se verifique um saldo positivo da nova regulamentação, alguns aspectos desta modalidade de seguro ainda dependerão de ajustes pontuais e de esclarecimentos futuros, a serem prestados pela SUSEP caso a caso, a partir da análise das apólices apresentadas para registro pelas seguradoras, já refletindo as novas regras da Circular SUSEP nº 553/2017.

\footnotetext{
${ }^{168}$ Conforme exposto por Gustavo Galrão em sua exposição no seminário "Café com Seguro Seguro D\&O - Circular 553" realizado pela ANSP, todo esse esforço das entidades de mercado e as críticas decorrentes da regulamentação proposta na Circular SUSEP n n 541/2016 justificam-se em razão da verificação dos potenciais impactos destas novas regras no mercado nacional de D\&O, uma vez que, tal como propostas, as novas previsões descaracterizariam esta modalidade de seguro frente às práticas internacionais, de modo que os tomadores do seguro voltar-se-iam para as seguradoras estrangeiras, buscando coberturas mais adequadas às suas demandas. Em termos numéricos, conforme ressaltado por Gustavo Galrão, verificou-se que as novas regras importariam a redução pela metade dos valores arrecadados com os prêmios do seguro $\mathrm{D} \& \mathrm{O}$, bem como significativa diminuição nas indenizações pagas e nas comissões de corretagem de seguro e resseguro. (GALRÃO, Gustavo; SALVADOR, Dinir; CICARELLI, Márcia. Café Com Seguro D\&O - Circular 553 - Ansp. Disponível em: <http://www.anspnet.org.br/site/galerias-devideos/cafe-com-seguro-do-circular-553-ansp/> . Acesso em: 08 de novembro de 2017).
} 
No que diz respeito à atuação da SUSEP em termos de política regulatória, deve ser objeto de reflexão o nível de intervenção do Estado no mercado securitário. Isso porque, conforme ressaltado por Bruno Miragem,

"se de um lado a intervenção do Estado justifica-se pela necessidade de assegurar a higidez econômico-financeira do plano de seguros e a segurança da garantia dos segurados e beneficiários, de outro pode frear o aperfeiçoamento da técnica securitária, reduzindo o nível de concorrência entre os segurados" 169.

Desse modo, ainda que confira maior segurança jurídica, deve-se reconhecer que, em certa medida, a regulamentação das modalidades de seguro pela SUSEP apresenta um aspecto negativo, qual seja, a limitação da atuação das seguradoras no sentido de desenvolver novos produtos, aprimorando as apólices e, por conseguinte, estimulando a concorrência neste mercado.

Esta foi justamente a crítica suscitada pelo presidente da Academia Nacional de Seguros e Previdência - ANSP, João Marcelo dos Santos, na abertura do seminário "Café com Seguro - D\&O - Circular SUSEP 553/2017', realizado em 14 de junho de 2017, em que pontuou que a estrutura deste produto seria mais bem debatida no âmbito das próprias seguradoras, que, visando atender a demanda e as especificidades do mercado D\&O, buscariam desenvolver as melhores condições para esta modalidade de seguro ${ }^{170}$.

Com a regulamentação da SUSEP, as seguradoras estarão vinculadas às regras fixadas pela referida circular, reduzindo o espaço para inovações e soluções alternativas, as quais, naturalmente, contribuem para o desenvolvimento do mercado.

Muito embora, reconheça-se a excelente postura adotada pela SUSEP ao receber as críticas do mercado após a edição da Circular SUSEP $\mathrm{n}^{\circ}$ 541/2016 e estabelecer diálogo com algumas entidades do setor para

\footnotetext{
${ }^{169}$ MIRAGEM, Bruno; CARLINI, Angélica (Org.). Op. Cit. p. 36.

${ }^{170}$ GALRÃO, Gustavo; SALVADOR, Dinir; CICARELLI, Márcia. Café Com Seguro D\&O Circular 553 - Ansp. Disponível em: <http://www.anspnet.org.br/site/galerias-de-videos/cafecom-seguro-do-circular-553-ansp/> . Acesso em: 08 de novembro de 2017.
} 
aprimorar a regulamentação do seguro D\&O, é importante dar um passo atrás e refletir se a interferência desta autarquia na estruturação das apólices de seguro representa o melhor caminho em termos de política regulatória.

Prestados esses esclarecimentos iniciais, passa-se a análise dos principais aspectos objeto de regulamentação pela referida Circular.

\subsubsection{Apólice à base de reclamação (claim made basis)}

Como exposto no item 3.2 acima, no início do seu desenvolvimento no mercado brasileiro, o seguro D\&O foi recepcionado como ramo do seguro de responsabilidade civil e, diante da ausência de regulamentação específica, passou a ser regido pelas cláusulas gerais aplicáveis às apólices à base de reclamações, inicialmente previstas na Circular SUSEP $\mathrm{n}^{\mathbf{o}}$ $336 / 2007$.

Deste modo, ao prever a contratação do seguro D\&O por meio de apólice à base de reclamações e afastar a possibilidade de transformação desta em apólice à base de ocorrências, a Circular SUSEP no 553/2017 apenas reafirmou a prática de mercado.

A opção por apólice a base de reclamações ou apólice à base de ocorrências diz respeito ao momento em que se considera ocorrido o sinistro que enseja a cobertura securitária.

Nos termos da definição adotada pela SUSEP, no caso de apólice à base de reclamação, a cobertura do seguro dependerá da verificação de dois requisitos (i) que os danos tenham ocorrido durante o período de vigência da apólice ou durante o período de retroatividade; e (ii) que o terceiro apresente a reclamação ao segurado, durante a vigência da apólice, durante o prazo complementar ou durante o prazo suplementar ${ }^{171}$.

\footnotetext{
${ }^{171}$ II - apólice à base de reclamações ("claims made basis"): forma alternativa de contratação de seguro de responsabilidade civil, em que se define, como objeto do seguro, o pagamento e/ou o reembolso das quantias, respectivamente, devidas ou pagas a terceiros, pelo segurado, a título de reparação de danos, estipuladas por tribunal judicial civil, decisão arbitral ou decisão administrativa, ou por acordo aprovado pela sociedade seguradora, desde que:
} 
No que diz respeito à ocorrência propriamente do fato danoso, verificase que, mesmo nas hipóteses em que o evento não ocorra durante a vigência do contrato, ele poderá ser objeto de cobertura do seguro D\&O desde que abarcado pelo período de retroatividade, que compreenderia o intervalo entre a data limite de retroatividade fixada na apólice e o início de sua vigência $^{172}$.

Em regra, a data limite de retroatividade é ajustada entre a seguradora e a tomadora no momento da contratação do seguro, devendo ser igual ou anterior à data de início da vigência da primeira apólice contratada, no caso de contratações sucessivas e ininterruptas. No entanto, conforme ressaltado por Clara Beatriz Lourenço Faria, no âmbito do seguro D\&O, a prática de mercado seria a estipulação de data limite de retroatividade ilimitada ${ }^{173}$.

Não obstante a ocorrência do fato danoso dentro do período de retroatividade, como exposto acima, para cobertura do seguro D\&O exigese um segundo requisito: que a reclamação referente ao ato danoso seja apresentada durante a vigência da apólice ou durante o prazo complementar ou suplementar ${ }^{174}$.

Conforme ressaltado por Roberta Medina Maia e Leonardo Burman, tendo em vista que o seguro D\&O prevê a cobertura de "riscos de latência prolongada",

“(...) a equiparação do sinistro à reclamação proposta contra o segurado pode mostrar-se muito vantajosa no caso do seguro $D \& O$ porque, em muitos casos, o

a) os danos tenham ocorrido durante o período de vigência da apólice ou durante o período de retroatividade; $\mathrm{e}$

b) o terceiro apresente a reclamação ao segurado:

1. durante a vigência da apólice; ou

2. durante o prazo complementar, quando aplicável; ou

3. durante o prazo suplementar, quando aplicável;

${ }^{172}$ FARIA, Clara Beatriz Lourenço de Faria. Op. Cit. p. 88.

${ }^{173}$ Ibidem, p. 88.

${ }^{174}$ Nos termos da Circular SUSEP n ${ }^{\circ} 553 / 2007$, o prazo complementar deverá ser concedido pela seguradora sem qualquer ônus ao segurado e se iniciará logo após o fim da vigência da apólice de seguro. Por sua vez, o prazo suplementar é de contratação facultativa pelo segurado, mediante o pagamento de prêmio adicional, e terá início após o encerramento do prazo complementar. (FARIA, Clara Beatriz Lourenço de. Op. Cit. pp. 88-91). 
segurado não será capaz de vislumbrar que de um determinado ato seu possa advir alguma reclamação ou mesmo um dano" ${ }^{175}$.

Não obstante a possibilidade de o seguro D\&O cobrir atos danosos ocorridos antes do início da vigência da apólice, mas dentro do período de retroatividade, o Tribunal de Justiça de São Paulo já se manifestou no sentido de que nos casos em que os fatores geradores sejam conhecidos pelos segurados antes da contratação do seguro e não sejam informados à seguradora afastar-se-ia a cobertura securitária, nos termos das ementas a seguir:

Apelação. Direito de empresa. Nulidade da sentença por cerceamento de defesa. Inocorrência. Suficiência da prova constante dos autos para o deslinde da causa. Seguro de responsabilidade civil (D\&O). Inexistência de cobertura para fatos geradores conhecidos pelos segurados ocorridos antes da assinatura do contrato. Recomposição indevida. Honorários de sucumbência. Manutenção do valor arbitrado por força do que dispõe o art. $85, \S 6^{\circ}$, do atual CPC. Redução inviável. Sentença mantida por seus próprios fundamentos, reproduzidos na forma do art. 252 do RITJSP. Precedentes do STJ e STF. Apelo a que se nega provimento. (Apelação Cível nº 1087421-51.2013.8.26.0100, $1^{\text {a }}$ Câmara de Direito Empresarial, TJSP, Des. Rel. Manoel de Queiroz Pereira Calças, julg. em 15.03.2017)

SEGURO. Ação de indenização securitária. Sentença de improcedência. Fatos que ensejam o pleito de indenização ocorreram antes da contratação. Ausência de informação da conduta no formulário de avaliação de risco. Decisum mantido por seus próprios e jurídicos fundamentos, nos termos do art. 252 do Regimento Interno desta Corte. Precedentes. Recurso não provido. (Apelação Cível ${ }^{\circ} 1095579$ 95.2013.8.26.0100, $1^{\text {a }}$ Câmara de Direito Privado, TJSP, Des. Rel. Rui Cascaldi, julg. em 23.02.2016).

\subsubsection{Tomador e Segurado}

Ao analisar as principais características do seguro de responsabilidade civil de administradores, verificou-se que, em muitos casos, esta modalidade de seguro é contratada não pelo próprio segurado, mas pela companhia na qual este último exerce cargo executivo e/ou de gestão, que, neste caso, figuraria como tomadora do seguro ${ }^{176}$.

Nos termos das definições constantes da Circular SUSEP n ${ }^{\circ}$ 553/2017, a tomadora do seguro responsabiliza-se junto à seguradora a atuar em nome do segurado no que concerne às condições contratuais, inclusive em relação

\footnotetext{
${ }^{175}$ MAIA, Roberta Mauro Medina; BURMAN, Leonardo Joseph. Op. Cit. pp. 153-154.

${ }^{176}$ RODRIGUES, Ana Carolina. Op. Cit. pp. 437-438.
} 
ao pagamento do prêmio e ao adiantamento das despesas para a sua defesa em juízo.

Nesse sentido, o Tribunal de Justiça de São Paulo reconheceu a legitimidade ativa da tomadora do seguro para propositura de ação em face da seguradora buscando reaver os valores adiantados aos segurados para pagamento de despesas judiciais, nos seguintes termos:

Seguro de responsabilidade civil para sócios e administradores de empresa. "D\&O". Directors and Officers. Legitimidade ativa da tomadora do seguro, que figura na apólice como segurada e efetuou o pagamento das despesas judiciais de seus administradores como terceira interessada, sub-rogando-se nos direitos que lhes pertenciam (arts. 304 e 346, III, do CC). Prescrição anual não reconhecida. Cláusula que prevê que estarão segurados os administradores responsabilizados pelas omissões e atos praticados no exercício de suas respectivas funções diretivas. Sócios e administradores que foram demandados por equívoco em ação de terceira empresa. Representação comercial de empresa estrangeira que se insere no objeto social da empresa segurada. Indenização devida. Ciência das ações antes da contratação não comprovada. Recurso provido. (Apelação n ${ }^{\circ}$ 0081391-51.2012.8.26.0100, 4 $4^{\mathrm{a}}$ Câmara de Direito Privado, TJSP, Des. Rel. Hamid Bdine, julg. em 13 de agosto de 2015.) (g.n).

Em que pese esta seja a forma usual de contratação do seguro D\&O, é possível que o próprio administrador tenha interesse em contratar diretamente apólice de seguro para garantir-se contra riscos decorrentes de sua atuação na administração de determinada companhia. No entanto, conforme descrito no item 3.2 acima, esta possibilidade de contratação não havia sido mencionada pela Circular SUSEP nº 541/2016.

A Circular SUSEP no 553/2017 altera a definição de "Segurado", constante de seu artigo $3^{\circ}$, inciso XXX, bem como a redação final do artigo $4^{\mathrm{o}}$, caput, de modo a prever expressamente a possibilidade de contratação deste seguro por pessoa física.

Deste modo, em paralelo à previsão de contratação do seguro pela própria companhia, identificada na Circular SUSEP no 553/2017 como "Tomadora do Seguro" ${ }^{177}$, a quem caberia atuar em nome do segurado

\footnotetext{
177 De acordo com a redação do artigo $3^{\circ}$, inciso XXXVI da Circular SUSEP n ${ }^{\circ}$ 553/2017, o "Tomador do Seguro" seria "a pessoa jurídica que contrata o seguro D\&O em benefício dos segurados, e que se responsabiliza, junto à seguradora, a atuar em nome destes com relação às condições contratuais do seguro, inclusive em relação ao pagamento do seguro (sem ônus para os
} 
perante a seguradora, inclusive em relação ao pagamento do prêmio, haveria ainda a possibilidade de contratação direta pelo próprio administrador (segurado).

Acrescenta-se, ainda, no $\S^{\circ}$ do artigo $4^{\circ}$ a previsão de que os processos de aprovação das apólices de seguro contratadas por pessoas físicas e pessoas jurídicas deverão ter números de processos distintos, por corresponderem a produtos distintos, e, por conseguinte, terão clausulados distintos.

Ainda no que diz respeito ao conceito de segurado, a Circular SUSEP $\mathbf{n}^{\circ}$ 553/2017 manteve o conceito de "Segurado (por extensão da cobertura)", conforme previsto na Circular SUSEP $\mathrm{n}^{\circ}$ 541/2016, mas incluiu nesta definição a pessoa jurídica "nos casos em que realize adiantamento de valores, elou assuma o compromisso de indenizar, pessoas que exerçam funções executivas elou cargos de administração" (artigo $3^{\circ}$, inciso XXXII, alínea “d”).

Afora as pessoas jurídicas, a extensão de cobertura prevista na referida Circular as pessoas físicas que (a) ocupem cargos executivos e/ou de gestão em subsidiárias e/ou coligadas da companhia; (b) por força de dispositivos legais, ocupem cargos na pessoa jurídica, tal como auditores, depositários, liquidantes e/ou interventores, etc.; e (c) contratadas pela companhia, sociedades subsidiárias e/ou coligadas para darem assessoria de qualquer natureza, tais como advogados, contadores, secretários, técnicos, entre outros.

Ressalta-se que, para as pessoas identificadas como "Segurado (por extensão de cobertura)", a garantia conferida pelo seguro depende da contratação de extensão de cobertura específica para cada um dos “segurados por extensão". juízo civil elou a indenizações cobertas pelo seguro". 


\subsubsection{Garantia e Cobertura Securitária}

As alterações mais relevantes trazidas pela Circular SUSEP n ${ }^{\circ}$ 553/2017 dizem respeito à garantia e cobertura securitária do seguro $\mathrm{D} \& \mathrm{O}$.

Antes de analisar as disposições da nova regulamentação da SUSEP, convém apresentar, em breve síntese, o padrão de cobertura oferecido pelo seguro D\&O.

Em linhas gerais, tal como exposto no item 3.1. deste capítulo, a cobertura do seguro D\&O tem por objetivo neutralizar os efeitos econômicos decorrentes da propositura de ações judiciais, procedimentos administrativos e/ou arbitrais, bem como outras reclamações movidas em face do administrador para apuração de sua responsabilidade na condução dos negócios sociais. Para tanto, prevê-se o pagamento pela seguradora (i) dos custos de defesa incorridos pelo administrador nos processos judiciais e administrativos movidos contra ele; (ii) das condenações pecuniária na hipótese de responsabilização do administrador; e (iii) dos acordos celebrados com a anuência da seguradora.

Conforme ressaltado por Márcia Cicarelli, estas três coberturas representariam os "pilares" do seguro D\&O, sendo expressamente adotadas nas apólices comercializadas no mercado ${ }^{178}$.

No entanto, como mencionado acima, com a edição da Circular SUSEP $\mathrm{n}^{\circ} 541 / 2016$, e, notadamente, pela forma como determinados termos teriam sido definidos, tais como "Fato Gerador", "Perda" e "Reclamação", teria sido alterada a tendência do mercado de adoção de apólices D\&O sob o modelo "all risks", passando a pender para um modelo de apólice de risco nomeado, em que somente os riscos descritos na apólice são cobertos pela seguradora.

\footnotetext{
${ }^{178}$ Nos termos de sua exposição no seminário "Café com Seguro - Seguro D\&O - Circular 553" realizado pela ANSP (GALRÃO, Gustavo; SALVADOR, Dinir; CICARELLI, Márcia. Café Com Seguro D\&O - Circular 553 - Ansp. Disponível em: <http://www.anspnet.org.br/site/galerias-devideos/cafe-com-seguro-do-circular-553-ansp/> . Acesso em: 08 de novembro de 2017).
} 
Nota-se, nesse sentido, que a inclusão do termo definido "Perda Indenizável", baseado justamente nos "três pilares" desta modalidade de seguro e aplicável "para fins de definição da cobertura básica da apólice" ${ }^{179}$, bem como a possibilidade conferida pelo artigo $7^{\circ}$, inciso I, alínea "a" da Circular SUSEP n ${ }^{\circ}$ 553/2017, de serem adotadas nas apólices de seguro definições equivalentes àquelas previstas na referida circular, buscaria uma reaproximação do modelo de apólice "all risks" ${ }^{180}$.

Não obstante as alterações promovidas pela nova circular, conforme ressaltado por Márcia Cicarelli e Gustavo Galrão, alguns conceitos ainda revelam problemas técnicos e apresentam definições mais restritivas do que a prática de mercado para o seguro $\mathrm{D} \& \mathrm{O}^{181}$.

Como exposto no capítulo 2, a responsabilidade dos administradores por atos de gestão se estende por diversas esferas do direito, de modo que eventuais custos de defesa ou condenações pecuniárias delas decorrentes poderão ser objeto de cobertura pelo seguro $\mathrm{D} \& \mathrm{O}$.

Na prática, conforme descrito por Clara Beatriz Lourenço de Faria, a inclusão de determinada perda indenizável na cobertura básica do seguro D\&O variaria conforme as condições da apólice negociadas por cada seguradora. Dito de outro modo, a estrutura das apólices de seguro se alteraria substancialmente a depender da seguradora, de forma que determinada cobertura poderia ser prevista como "cobertura adicional" em determinada apólice e, em outra, estar incluída na garantia básica do seguro $^{182}$.

\footnotetext{
${ }^{179}$ Artigo $3^{\circ}$, inciso XXIII - perda indenizável: para fins de definição da cobertura básica da apólice, define-se como perda indenizável os itens indicados abaixo quando decorrentes de uma relação contra o segurado coberta pela apólice: a) quaisquer Custos de Defesa; b) indenização; ou c) acordos, desde que seja com anuência prévia por escrito da seguradora.

${ }^{180}$ GALRÃO, Gustavo; SALVADOR, Dinir; CICARELLI, Márcia. Café Com Seguro D\&O Circular 553 - Ansp. Disponível em: <http://www.anspnet.org.br/site/galerias-de-videos/cafecom-seguro-do-circular-553-ansp/> . Acesso em: 08 de novembro de 2017.

181 Ibidem.

${ }^{182}$ FARIA, Clara Beatriz de Lourenço. Op. Cit. p. 98.
} 
No entanto, analisando o padrão de cobertura adotado pelas seguradoras, a autora apresentou esquema organizando as diferentes esferas de responsabilização e a respectiva cobertura (cobertura básica, adicional ou exclusão) pelo seguro D\&O. Em síntese, verificou-se que, via de regra, estão cobertos os custos de defesa em todas as esferas (cível, penal, tributário, trabalhista, previdenciário, falimentar, concorrencial e consumerista), ressalvado os custos na esfera ambiental. Por sua vez, em alguns casos, como no âmbito tributário, trabalhista e previdenciário, a garantia de indenizações exigia a contratação de cobertura adicional ${ }^{183}$.

Em que pese este "padrão de mercado", com a edição da Circular SUSEP no 553/2017, Márcia Cicarelli aponta uma possível tendência de que algumas coberturas, que antes poderiam ser tratadas como cobertura básica do seguro, passariam a ser tratadas como extensões de cobertura ${ }^{184}$.

Nesse sentido, Márcia Cicarelli ressalta que o conceito de "reclamação" constante da referida circular refere-se tão somente aos procedimentos administrativos e arbitrais e às ações cíveis e criminais, não havendo, portanto, qualquer menção às ações fiscais, trabalhistas e previdenciárias, que teriam grande incidência nesta modalidade de seguro.

Outra crítica apresentada por Márcia Cicarelli diz respeito à desnecessária restrição imposta pela definição de "fato gerador" e "ato danoso", que dariam especial ênfase à conduta culposa individualizada do administrador, quando, na realidade, verificar-se-ia que, em determinadas situações, especialmente no âmbito trabalhista e consumerista, o administrador seria envolvido em reclamações tão somente em razão do cargo por ele ocupado ou da função desempenhada na administração da companhia.

\footnotetext{
${ }^{183}$ Ibidem, pp. 118-119.

${ }^{184}$ GALRÃO, Gustavo; SALVADOR, Dinir; CICARELLI, Márcia. Café Com Seguro D\&O Circular 553 - Ansp. Disponível em: <http://www.anspnet.org.br/site/galerias-de-videos/cafecom-seguro-do-circular-553-ansp/> . Acesso em: 08 de novembro de 2017.
} 
Até mesmo na esfera criminal, em que, a princípio, não se prescindiria da demonstração da culpa lato sensu do agente, seria possível identificar, em casos de crimes tributários e ambientais, manifestações jurisprudenciais imputando responsabilidade ao administrador sem a demonstração de culpa ou, ainda, a individualização de sua conduta, nos termos do item 2.1.3 acima.

Por esta razão, concluir-se-ia que as definições conferidas a "fato gerador" e "ato danoso" afastariam da cobertura securitária situações de risco aos quais está exposto o administrador e que antes da regulamentação poderiam ser objeto de cobertura pelo seguro.

Ainda no que diz respeito à falta de técnica demonstrada pela SUSEP na definição de alguns termos que impactam diretamente na cobertura do seguro, a autora ressaltou a inclusão da companhia tomadora como "segurada por extensão de cobertura" nos casos em que esta adiante os custos de defesa ou às indenizações devidas pelo administrador. Esta seria justamente a hipótese da cobertura Side $B$.

Sobre este ponto, cabe destacar que a forma de contratação da cobertura do seguro D\&O pode variar, a depender da pessoa que suportou o ônus dos custos de defesa e indenizações, bem como do destinatário da cobertura. Tradicionalmente, apontam-se três modalidades de apólices.

A primeira delas, conhecida como side A, pressupõe o pagamento direto pela seguradora ao administrador dos valores que ele tenha despendido com custos de defesa e condenações pecuniárias, decorrentes de sua responsabilização por atos praticados na gestão social e cobertos pelo seguro $^{185}$.

Por sua vez, as coberturas side $B$ e side $C$ estão voltadas à proteção do patrimônio social da própria companhia tomadora. A cobertura side $B$, também conhecida como cobertura de reembolso, busca ressarcir a

\footnotetext{
${ }^{185}$ FARIA, Clara Beatriz Lourenço de. Op. Cit. p. 79.
} 
companhia dos custos suportados com a defesa do administrador ou com o pagamento das indenizações atribuídas a este último nas hipóteses em que a companhia tenha adiantado esses valores ao administrador e/ou assumido a obrigação de mantê-lo indene.

A cobertura side $C$ (corporate entity coverage) tem por finalidade resguardar o patrimônio social dos efeitos econômicos negativos decorrentes de ações movidas em face da própria companhia ${ }^{186}$.

Na visão de Márcia Cicarelli, não seria o mais adequado incluir a companhia tomadora como "segurada (por extensão de cobertura)", uma vez que no caso da cobertura Side $B$, a responsabilidade continua sendo do administrador, sendo que apenas o ônus econômico é suportado pela companhia.

Não obstante as críticas apresentadas até então, convém ressaltar que a Circular SUSEP $n^{\circ} 553 / 2017$ trouxe previsões muito importantes para assegurar a adequação da regulamentação do seguro D\&O às práticas de mercado.

Nesse sentido, destaca-se que a garantia dos custos de defesa e honorários advocatícios passou a ser indicada como cobertura básica do seguro D\&O, tendo sido alteradas as redações do artigo $5^{\circ}$, $\S \S 3^{\circ}$ e $4^{\circ}$ e do artigo $7^{\circ}$, inciso I, alínea " $b$ " e inciso III, alínea "a" para refletirem esta nova orientação.

Ressalta-se que o $\S 4^{\circ}$, do artigo $5^{\circ}$, exige a inclusão de menção expressa ao direito de "regresso" - melhor dizendo, direito de reembolso - da seguradora nos casos em que os danos causados a terceiros decorram de atos ilícitos dolosos, ou em que o segurado reconheça a sua responsabilidade.

\footnotetext{
${ }^{186}$ WETERINGS, Wim. Op. cit. p. 9.
} 
Isso porque, em regra, os custos de defesa e honorários advocatícios são adiantados ao segurado antes da decisão final da reclamação movida por terceiro, razão pela qual, caso venha a se demonstrar ao final da demanda que o segurado agiu com dolo ou ele confesse a sua conduta dolosa, a seguradora terá direito de regresso quanto ao montante adiantado “indevidamente" ${ }^{187}$. Diante desta disposição, resta claro, ainda, que, caso o segurado celebre uma delação premiada admitindo a participação em ato fraudulento ou em crime de modalidade dolosa, tal como crime de corrupção ou lavagem de dinheiro, não fará jus à cobertura do seguro.

Márcia Cicarelli esclarece que, no âmbito criminal, a cobertura dos custos de defesa ganha especial importância, não somente em razão dos altos valores envolvidos despendidos em honorários advocatícios ${ }^{188}$.

Passou-se a prever também, mas neste caso como cobertura adicional específica a ser contratada pelo tomador, a garantia dos “danos causados a terceiros, aos quais a sociedade tenha sido responsabilizada, em consequência de atos ilícitos culposos praticados por pessoa física [administrador]" (artigo $5^{\circ}, \S 6^{\circ}$ ). Trata-se da já mencionada “cobertura C", que havia sido omitida da Circular SUSEP no 541/2016.

De acordo com os esclarecimentos prestados por Gustavo Galrão no seminário realizado pela ANSP a respeito do seguro D\&O, ao incluir tal cobertura na Circular SUSEP $n^{\circ}$ 553/2017, a SUSEP manifestou entendimento no sentido de que tal garantia à sociedade é admitida no âmbito do seguro D\&O somente quando a reclamação movida por terceiro envolver tanto a pessoa jurídica quanto o administrador ${ }^{189}$.

\footnotetext{
187 Nos termos ressaltados por Clara Beatriz Lourenço de Faria, “(...) a seguradora não tem legitimidade para fazer esse juízo de valor e negar a cobertura de plano. Assim, ela adianta os custos de defesa em qualquer hipótese, mas se houver condenação por fraude ou dolo, o administrador tem que reembolsá-la". (FARIA, Clara Beatriz Lourenço de. Op. Cit. p. 100).

${ }^{188}$ GALRÃO, Gustavo; SALVADOR, Dinir; CICARELLI, Márcia. Café Com Seguro D\&O Circular 553 - Ansp. Disponível em: <http://www.anspnet.org.br/site/galerias-de-videos/cafecom-seguro-do-circular-553-ansp/> . Acesso em: 08 de novembro de 2017.

${ }^{189}$ Ibidem.
} 
Caso a demanda seja proposta apenas em face da sociedade, a cobertura dos custos de defesa e das indenizações dela decorrentes não serão objeto desta modalidade de seguro, sendo necessária a contratação de seguro de responsabilidade civil geral.

Nesse sentido, incluiu-se parágrafo único ao artigo $6^{\circ}$, de modo a esclarecer que, quando estes riscos forem comercializados como cobertura básica, devem ser enquadrados no ramo de responsabilidade civil geral e não no seguro D\&O.

Dito de outro modo, impossibilita-se a contratação de seguro D\&O com cobertura exclusiva para a companhia. Caso venha a ser garantido tal risco no âmbito do seguro D\&O deverá ocorrer por meio de cobertura adicional, atrelada à cobertura básica em benefício dos administradores da companhia.

Quanto às previsões de cobertura já refletidas na Circular SUSEP no 541/2016, destaca-se que foi mantida a possibilidade de cobertura de multas e penalidades. No entanto, aprimorada a redação, ao invés de referir-se a multas e penalidades "contratuais", tal como previsto na Circular revogada, a Circular SUSEP nº 553/2017 fala em multas e penalidades "cíveis", além das administrativas, já indicadas.

Com a elaboração do Projeto de Lei da Câmara n ${ }^{\circ}$ 129/2017, que aguarda a sanção presidencial, a cobertura de multas e penalidades ganha maior relevância para esta modalidade de seguro, sendo certo que o incremento dos valores das multas aplicadas pela CVM impactará diretamente na precificação dos prêmios cobrados pelas seguradoras, cuja exposição a risco aumentará consideravelmente ${ }^{190}$.

\footnotetext{
${ }^{190}$ Em entrevista concedida à Capital Aberto em 29 de outubro de 2017, sob o título " $D \& O$ mais caro", Paula Lopes, diretora da corretora de seguros Marsh, o aumento dos valores das multas aplicadas pela CVM e pelo Banco Central irá repercutir diretamente no prêmio dos seguros que prevejam cobertura de multa, em especial para as instituições financeiras e companhias de capital aberto. Acrescentou, ainda, que, atualmente, a única seguradora que já está comercializando o seguro com cobertura de multas e penalidades é a Chubb Brasil Companhia de Seguros, que, para este tipo de cobertura, cobra um adicional de 30 a $40 \%$ sobre o valor da apólice básica. (FOLEGO, Thais. D\&O mais caro. In: Capital Aberto, 29 de outubro de 2017. Disponível em:
} 
A cobertura de acordos celebrados pelo segurado também já estava prevista no artigo $5^{\circ}$, caput da Circular SUSEP n ${ }^{\circ}$ 541/2016, contudo, não com a mesma clareza da Circular SUSEP no 553/2017, que, além de manter a redação do referido dispositivo, incluiu no conceito de "perdas indenizáveis" os acordos celebrados com a anuência da seguradora.

No entanto, nem sempre foi pacífico o entendimento de que os valores ajustados no acordo seriam objeto de cobertura pelo seguro D\&O.

Conforme ressaltado por Marília de Cara em sua tese de mestrado sobre o tema ${ }^{191}$, em um primeiro momento, em vista do entendimento manifestado pela SUSEP em parecer exarado pela Procuradoria de Assuntos Societários e Regimes Especiais quanto à impossibilidade de cobertura de multas e penalidades pelo seguro D\&O, conforme exposto acima, passou-se a discutir se os valores ajustados em termo de compromisso equiparar-se-iam à multa pecuniária imposta pela CVM em processos sancionadores. Caso assim se entendesse estaria afastada a cobertura do seguro D\&O para os casos de termo de compromisso celebrados por administradores de companhias abertas.

Muito embora se defenda o caráter indenizatório (e não sancionador) das obrigações pecuniárias ajustadas no termo de compromisso, voltadas ao ressarcimento de prejuízos causados a determinados investidores, passíveis de identificação, ou ao mercado como um todo, a partir da edição da Circular SUSEP n⿳ 541/2016 tal discussão foi superada, posto que passou a ser admitida a cobertura de multas e penalidades cíveis e administrativas.

Ainda que o incremento do teto máximo de multa pecuniária se refira às hipóteses de condenação do investigado, acredita-se que a alteração proposta pelo Projeto de Lei da Câmara no 129/2017, influenciará diretamente no montante dos termos de compromisso negociados por esta

http://www.multclipp.com.br/verNoticia.aspx?n=6iM2WNehP1k\%3d\&e=I6sWPfMdnf4\%3d. Acesso em: 03 de novembro de 2017).

${ }^{191}$ CARA, Marília de. Op. Cit. 94-95. 
autarquia, cuja análise de conveniência leva em consideração, entre outros elementos, o valor das penalidades que eventualmente poderiam ser impostas em caso de condenação do acusado ${ }^{192}$.

Outra importante alteração promovida pela Circular SUSEP n ${ }^{\circ} 553 / 2017$ diz respeito à restrição da vedação a referências a legislações estrangeiras somente às apólices cuja cobertura se dê no território nacional, conforme nova redação conferida ao caput e $\$ 1^{\circ}$ do artigo 12 , a partir da qual se reabre a possibilidade de contratação de apólices com cobertura que se estenda a jurisdições internacionais, o que havia sido inviabilizado em razão da proibição de referência a legislação estrangeira.

No que diz respeito às situações não abordadas pela Circular SUSEP n ${ }^{\circ}$ 553/2017, merece especial atenção a hipótese de cobertura de custos de defesa e eventuais condenações pecuniárias decorrentes de ação de responsabilidade movida pela própria companhia tomadora do seguro. Como visto no capítulo anterior, a ação social é o principal instrumento de que dispõe o ente social para reparar os prejuízos decorrentes da conduta do administrador na gestão social.

Em que pese à importância desta ação, é certo que, neste caso, há uma dificuldade conceitual, pois o sujeito lesado pelo administrador é, ao mesmo tempo, a pessoa responsável pela contratação do seguro em seu benefício. Diante disso, questiona-se se seria possível incluir a companhia tomadora na expressão "terceiro" a que se refere o conceito de "fato gerador".

\footnotetext{
${ }^{192}$ Também em entrevista à Capital Aberto, conforme mencionada na nota de rodapé acima. Fernando Saccon, responsável pelas linhas financeiras da seguradora Zurich Seguros, afirmou que, mesmo os seguros que não preveem cobertura de multas e penalidades, mas, tão somente a garantia de termos de compromisso e termos de ajustamento de conduta, serão impactados pelo aumento do patamar máximo de multas, uma vez que "para que o acordo faça sentido para a CVM, o executivo que está sendo investigado terá que oferecer um valor maior para fechar o termo". (FOLEGO, Thais. D\&O mais caro. In: Capital Aberto, 29 de outubro de 2017. Disponível em: http://www.multclipp.com.br/verNoticia.aspx?n=6iM2WNehP1k\%3d\&e=I6sWPfMdnf4\%3d. Acesso em: 03 de novembro de 2017).
} 
Roberta Mauro Medina e Leonardo Burman concluem ser razoável equiparar o tomador ao terceiro lesado, pelas seguintes razões:

"Se a contratação da apólice D\&O mostra-se válida justamente por evitar prejuízos também à tomadora do seguro - sendo essa a razão primordial das obrigações por ela contraídas - não importa se tais prejuízos representam danos causados a terceiros por atos do administrador ou aqueles que abalam diretamente a empresa. "193.

Nesse sentido, Clara Beatriz Lourenço de Faria acompanha o entendimento dos referidos autores, mas ressalva que, para tanto, será necessária a contratação da respectiva cobertura adicional ${ }^{194}$.

Ainda no que diz respeito à cobertura do Seguro D\&O, convém fazer referência à decisão do Tribunal de Justiça do Estado de São Paulo ${ }^{195}$ que reconheceu que os atos praticados pelos administradores da tomadora no cumprimento de mandato outorgado a esta sociedade configurariam atos de gestão. Isso porque o próprio objeto social da tomadora indicava que estava sociedade prestava "assessoria na estruturação de negócios e oportunidades no mercado financeiro", de modo que fazia parte das atividades sociais a representação de outras sociedades.

\subsubsection{Exclusões de Cobertura}

Nos termos do artigo $6^{\circ}$ da Circular SUSEP $n^{\circ}$ 553/2017, estão expressamente excluídos da garantia os riscos de responsabilização dos segurados decorrentes de (i) danos causados a terceiros, pelos segurados, oriundos de atos por eles praticados não na qualidade de administradores e/ou gestores da companhia e/ou de suas subsidiárias ou coligadas, mas como cidadãos comuns; (ii) danos causados a terceiros, pelos segurados, no exercício de profissões liberais que não estão relacionadas ao exercício de seus cargos na administração e/ou gestão da companhia; e (iii) danos ambientais.

\footnotetext{
${ }^{193}$ MAIA, Roberta Mauro; BURMAN, Leonardo Joseph. Op. Cit. p. 139.

${ }^{194}$ FARIA, Clara Beatriz Lourenço de. Op. Cit. pp. 107-108.

195 Apelação no 0081391-51.2012.8.26.0100, 4ª Câmara de Direito Privado, TJSP, Des. Rel. Hamid Bdine, julg. em 13 de agosto de 2015.
} 
Tais situações se enquadrariam em outros ramos do seguro de responsabilidade civil, quais sejam, o seguro de responsabilidade civil geral, o seguro de responsabilidade profissional e o seguro de riscos ambientais, todos objeto de contratação específica.

Ademais, por força legal, exclui-se a cobertura de atos ilícitos dolosos e/ou fraudulentos.

Recentemente, o Superior Tribunal de Justiça - STJ manifestou-se em julgamento de recurso especial ${ }^{196}$ acerca da exclusão de cobertura do seguro D\&O no caso de ocorrência do ilícito de insider trading, que pressupõe a negociação de valores mobiliários de posse de informação relevante ainda não divulgada ao mercado, prática vedada pelo artigo $155, \S \S 1^{\circ}$ e $4^{\circ}$ da Lei das S.A c/c artigo 13 da Instrução CVM nº 358, de 3 de janeiro de 2002.

Nesta oportunidade, o STJ ressaltou que os riscos garantidos por meio desta modalidade de seguro dizem respeito a eventuais prejuízos causados por atos de gestão de administradores, que, na condução da atividade social, agiram com culpa, excluindo-se a cobertura de atos dolosos, em linha com o disposto no artigo 762 do Código Civil.

Nesse sentido, concluiu que:

"o seguro de $R C D \& O$ somente possui cobertura para (i) atos culposos de diretores, administradores e conselheiros; (ii) praticados no exercício de suas funções (atos de gestão). Em outras palavras, atos fraudulentos e desonestos de favorecimento pessoal e práticas dolosas lesivas à companhia e ao mercado de capitais, a exemplo do insider trading, não estão abrangidos na garantia securitária".

Desse modo, além de configurar ato doloso, a negociação de valores mobiliários de companhia aberta supostamente de posse de informação privilegiada não representaria ato de gestão, mas sim ato pessoal, na condição de acionista, voltado à obtenção de benefícios financeiros próprios.

\footnotetext{
${ }^{196}$ REsp n ${ }^{\circ} 1.601 .555$, Terceira Turma do Superior Tribunal de Justiça, Min. Rel. Ricardo Villas Bôas, julg. em 14 de fevereiro de 2017.
} 
No caso em análise, concorreu ainda para a exclusão de cobertura do seguro D\&O o fato de a tomadora do seguro ter omitido a existência de investigação conduzida pela CVM para apuração de eventual conduta irregular decorrente da negociação de ações da tomadora antes da divulgação de fato relevante, hipótese que vai de encontro ao princípio da boa-fé que norteia os contratos de seguro, tal como exposto no item 1.3.3 acima.

É imprescindível ressaltar, no entanto, que a exclusão da cobertura do seguro D\&O em decorrência da prática de ato doloso pelo administrador depende (a) de confissão por parte do segurado do ato ilícito doloso ${ }^{197}$; ou (b) transito em julgado de decisão judicial, arbitral ou administrativa reconhecendo a prática de ato doloso pelo segurado, tal como reconheceu o Tribunal de Justiça do Estado de São Paulo no julgamento de apelação cível, nos termos a seguir:

"Assim, ainda que inexista confissão do apelante de que tenha cometido atos dolosos que tenham levado à Reclamação em razão da qual se quer a cobertura do seguro, como também não haja decisão judicial pela qual ficou configurada conduta dolosa do apelante, relativamente à reclamação, necessários para que se configure o ato doloso, estão presentes as demais hipóteses excludentes da cobertura securitária (omissão de informações relevantes e agravamento intencional do risco)" ${ }^{198}$ (g.n.).

Por esta razão, não comprovada a prática de ato doloso, seja por confissão do segurado, seja por decisão transitada em julgado, caberá à seguradora adiantar os custos de defesa.

Nos casos em que importar confissão do acusado quanto à sua participação em ilícito doloso, o "acordo administrativo em processo de previsão" previsto no Projeto de Lei da Câmara n 129/2017 e inserido no

\footnotetext{
${ }^{197}$ Márcia Cicarelli esclarece em sua exposição no seminário "Café com Seguro - D\&O - Circular SUSEP 553/2017”, realizado em 14 de junho de 2017, que o reconhecimento da responsabilidade só afasta a cobertura do seguro $\mathrm{D} \& \mathrm{O}$ em casos de confissão de atos ilícitos dolosos, o que não se confunde com a admissão da prática de ato culposo ou ainda a celebração de acordos previamente aprovados pela seguradora. (GALRÃO, Gustavo; SALVADOR, Dinir; CICARELLI, Márcia. Café Com Seguro D\&O - Circular 553 - Ansp. Disponível em: $<\mathrm{http} / / /$ www.anspnet.org.br/site/galerias-de-videos/cafe-com-seguro-do-circular-553-ansp/> Acesso em: 08 de novembro de 2017).

${ }_{198}$ Apelação Cível no ${ }^{\circ}$ 0172250-84.2010.8.26.0100, 10ª Câmara de Direito Privado, TJSP, Des. Rel. Roberto Maia, julg. em 25 de junho de 2013.
} 
rol de competências da CVM e do Banco Central, não poderá ser objeto de garantia pelo seguro de responsabilidade civil de administradores.

No que diz respeito às entidades públicas organizadas sob a forma de sociedade anônima e sujeitas às regras da Lei das S.A., vale ressaltar o posicionamento que se consolidou nas decisões do Tribunal de Contas da União - TCU a partir do Acórdão 3116/2013.

Nesta ocasião, o plenário do TCU foi instado a se manifestar sobre a possibilidade de a companhia subsidiar a defesa de integrantes ou exintegrantes de sua administração em processos judiciais e administrativos em razão de atos praticados no exercício de suas funções. Sobre esse tema já havia manifestação anterior do Tribunal no âmbito dos Acórdãos 35/2000, 313/2008 e 1.179/2008, em que se entendeu que as entidades públicas não poderiam utilizar advogados de seus quadros para atuarem na defesa de dirigentes e empregados da empresa.

No entanto, por ocasião da análise de disposição estatutária da Eletrobras ${ }^{199}$, reconheceu-se que esta argumentação não se adequava ao regime de responsabilidade previsto na Lei das S.A., que afasta a responsabilidade do administrador por ato regular de gestão. Analisou-se, ainda, neste cenário, a contratação de seguro D\&O pela referida sociedade.

Concluiu-se que a cobertura do referido seguro não poderia alcançar atos ilícitos ou ilegais praticados dolosamente ou com culpa pelo administrador, sendo que, com relação à conduta culposa, caso comprovado

\footnotetext{
199“Art. 29. Os membros do conselho de administração e da diretoria executiva responderão, nos termos do art. 158 da Lei 6.404/1976, individual e solidariamente, pelos atos que praticarem e pelos prejuízos que deles decorram para a companhia.

$\$ 1^{\circ}$ A Eletrobras assegurará aos integrantes e integrantes da diretoria executiva e dos conselhos de administração e fiscal a defesa em processos judiciais e administrativos contra eles instaurados pela prática de atos no exercício do cargo ou função, desde que não haja incompatibilidade com os interesses da companhia.

$\S 2^{\circ}$ O benefício previsto no parágrafo primeiro deste artigo aplica-se, no que couber e a critério do conselho de administração, aos ocupantes e ex-ocupantes de função de confiança e demais empregados regularmente investidos de competência por delegação dos administradores.

$\S 3^{\circ}$ A forma do benefício mencionado será definida pelo conselho de administração, ouvida a área jurídica da Eletrobras".
} 
que foram adotadas todas medidas normativas legais esperadas de um "homem médio", admitir-se-ia a sua cobertura pelo seguro.

Na visão do Tribunal, não obstante a existência de orientação no âmbito da SUSEP no sentido de que não seria possível a cobertura de multas e penalidades, não haveria uma definição legal quanto ao conceito de interesse legítimo objeto do seguro, razão pela qual a sua delimitação deveria seguir os parâmetros descritos acima, qual seja, a não cobertura de atos dolosos.

Nesse sentido, afirmou-se que:

"verificação do dolo ou culpa na prática de um ato, deve ser o fundamento da decisão desautorizar ou não o pagamento de multa pela seguradora em nome do segurado. Referida análise é produzida no estudo do sinistro e deve apontar se ao praticar o ato, o administrador objetivou lesar terceiros para obter vantagem ilícita ou não se cercou dos devidos cuidados mínimos"

Verifica-se desta decisão, mantida pelo Tribunal no âmbito do Acórdão 176/2017, que há uma ampliação da hipótese de exclusão de cobertura regularmente prevista nas apólices desta modalidade de seguro e expressamente estabelecida nas Circulares SUSEP nº 541/2016 e 553/2017, posto que, além de excluir a cobertura de atos dolosos, afasta também a garantia da conduta culposa do administrador.

No que diz respeito à exclusão dos riscos ambientais, destaca-se que, antes da regulamentação do seguro D\&O, a SUSEP vinha aceitando a cobertura de riscos ambientais, desde que mediante a contratação de produto secundário.

Muito embora alguns participantes do mercado entendam acertada a decisão da SUSEP de afastar a cobertura de riscos ambientais, em vista da amplitude técnica desse seguro e dos direitos coletivos/difusos envolvidos, em artigo para a Revista Opinião.Seg, Fábio Figueira e Andrea Piccolo argumentam que

${ }^{200}$ Acórdão TCU 3116/2013 - Plenário, sessão de 20 de novembro de 2013. 
“(...) essa questão poderia ser mais bem analisada pela SUSEP, notadamente no que se refere aos custos de defesa e casos onde a seguradora tenha condições de oferecer a cobertura e calcular o respectivo prêmio, sujeita a certas limitações que podem ser previamente estabelecidas/aprovadas, conforme já vinha ocorrendo" 201.

\subsubsection{Limite Máximo de Indenização (LMI), Limite Agregado (LA) e Limite Máximo de Garantia (LMG)}

Tal como disposto originalmente na Circular SUSEP $n^{\circ}$ 541/2016, a nova regulamentação manteve a previsão de limitações ao montante a ser indenizado pela seguradora em caso de sinistro. Para tanto, a Circular SUSEP $n^{\circ} 553 / 2017$ prevê os seguintes conceitos: (i) limite máximo de indenização por cobertura (LMI); (ii) limite agregado (LA); e (iii) limite máximo de garantia (LMG).

Tanto o limite máximo de indenização quanto o limite agregado deverão, obrigatoriamente, estar previstos na apólice do seguro D\&O, conforme determinação do artigo 10 da referida Circular ${ }^{202}$.

Enquanto o LMI busca estabelecer um valor máximo a ser indenizado para cada cobertura contratada pelo segurado e/ou tomador, com relação às reclamações decorrentes de um mesmo fato gerador, o LA tem por objetivo delimitar o valor total máximo para cada cobertura, considerando não apenas as despesas com reclamações decorrentes de um mesmo fator gerador, mas sim os custos relacionados com todos os sinistros ocorridos.

Ademais, cumpre ressaltar que, nos termos do parágrafo único, do artigo 10, "os limites máximos de indenização de cada cobertura (LMI), assim como os respectivos limites agregados (LA), não se somam nem se comunicam". Desse modo, afasta-se a possibilidade de que, esgotadas as verbas para determinada cobertura, o segurado passe a recorrer ao limite de outra cobertura.

\footnotetext{
${ }^{201}$ FIGUEIRA, Fábio; PICCOLO, Andrea. O seguro D\&O e a Circular SUSEP 553/2017”. In: Revista Opinião.Seg. Editora Roncarati, no 14, julho 2017, p. 157.

${ }^{202}$ Art. 10. Para cada cobertura deve ser estipulada a existência de um limite máximo de indenização (LMI) e de um limite agregado (LA). Parágrafo único. Deve ser ressaltado que os limites máximos de indenização de cada cobertura (LMI), assim como os respectivos limites agregados (LA), não se somam nem se comunicam.
} 
Por sua vez, o LMG é facultativo e representa o limite máximo de responsabilidade da seguradora nas situações em que uma reclamação (ou série de reclamações) decorrente de determinado fato gerador é garantida por mais de uma das coberturas contratadas pelo segurado e/ou tomador.

\subsubsection{Direito de reembolso ou pagamento direto a terceiro}

Não obstante a controvérsia existente quanto à natureza da obrigação assumida pela seguradora, que pressuporia ou o dever de reembolsar ou o dever de manter indene o segurado, a Circular SUSEP no 553/2017 não apresentou uma definição sobre o assunto, adotando "solução conciliatória".

Nesse sentido, ao tratar da garantia assumida pela seguradora perante o segurado, o artigo $5^{\circ}$, caput, refere-se ao dever de reembolsá-lo das indenizações que for obrigado a pagar em razão de eventual sentença judicial ou arbitral condenatória ou de acordo celebrado com terceiro prejudicado. A partir desta previsão, deduz-se, a princípio, que não caberia o pagamento direto da seguradora ao terceiro lesionado.

Contudo, o $\S 2^{\circ}$ deste mesmo dispositivo prevê que:

"[a] o invés de reembolsar o segurado, a seguradora poderá: (i) oferecer a possibilidade de pagamento direto aos terceiros prejudicados; ou (ii) reembolsar o tomador, caso este tenha adiantado, para o segurado, total ou parcialmente, quantias correspondentes às indenizações cobertas por este seguro".

Deste modo, conclui-se que, em regra, o pagamento da indenização será realizado pelo próprio segurado, o qual fará jus ao recebimento do reembolso pela seguradora, nos termos da apólice $\mathrm{D} \& \mathrm{O}$ contratada, sendo facultado à seguradora oferecer a possibilidade de pagamento direto aos terceiros prejudicados.

Cumpre observar que a possibilidade de o terceiro lesado acionar diretamente à seguradora vinha sendo objeto de discussão não somente no âmbito do seguro D\&O como em outras modalidades de seguro, com manifestações favoráveis por parte da doutrina, que recorre à redação do 
artigo 787 para fundamentar o seu posicionamento. $\mathrm{O}$ referido dispositivo prevê que "[n]o seguro de responsabilidade civil, o segurador garante o pagamento de perdas e danos devidos pelo segurado a terceiro”.

Segundo alguns autores ${ }^{203}$, a partir desta redação, o legislador teria esclarecido que a pessoa destinatária da indenização devida em virtude do seguro de responsabilidade civil é o terceiro lesado e não o segurado, de modo que não haveria razão para impedir a propositura de ação direta pela vítima do dano.

No entanto, em análise de recurso repetitivo sobre o tema ${ }^{204}$, o STJ entendeu que não caberia a terceiro prejudicado a propositura de ação indenizatória direta e exclusivamente em face da seguradora do autor do dano, uma vez que a obrigação de indenização por parte da seguradora dependeria da prévia verificação da responsabilidade do segurador, autor do suposto dano, a quem caberia se defender dos fatos expostos, nos resumidos da ementa a seguir:

PROCESSUAL CIVIL. RECURSO ESPECIAL REPRESENTATIVO DE CONTROVÉRSIA. ART. 543-C DO CPC. AÇÃO DE REPARAÇÃO DE DANOS AJUIZADA DIRETA E EXCLUSIVAMENTE EM FACE DA SEGURADORA DO SUPOSTO CAUSADOR. DESCABIMENTO COMO REGRA.

1. Para fins do art. 543-C do CPC:

1.1. Descabe ação do terceiro prejudicado ajuizada direta e exclusivamente em face da Seguradora do apontado causador do dano.

1.2. No seguro de responsabilidade civil facultativo a obrigação da Seguradora de ressarcir danos sofridos por terceiros pressupõe a responsabilidade civil do segurado, a qual, de regra, não poderá ser reconhecida em demanda na qual este não interveio, sob pena de vulneração do devido processo legal e da ampla defesa.

2. Recurso especial não provido.

Por fim, ressalta-se que tal posicionamento restou refletida no teor da Súmula 529 do STJ, que repete a disposição da ementa acima: "No seguro de responsabilidade civil facultativo, não cabe o ajuizamento de ação pelo terceiro prejudicado direta e exclusivamente em face da seguradora do apontado causador do dano".

\footnotetext{
${ }^{203}$ ALVIM, Pedro. Op. Cit. pp. 142-144; e TZIRULNIK, Ernesto; CAVALCANTI, Flávio de Queiroz B.; PIMENTEL, Ayrton. Op. Cit. pp. 213-216.

${ }^{204}$ REsp 962.230-RS, Rel. Min. Luis Felipe Salomão, julg. em 08 de fevereiro de 2012.
} 


\subsection{O risco moral (moral hazard)}

Apresentadas as características particulares do seguro de responsabilidade civil de administradores e a regulamentação aplicável a esta modalidade securitária, convém tecer algumas considerações acerca da crítica levantada por alguns estudiosos a respeito do risco moral associado aos seguros de responsabilidade civil e, em especial neste caso, ao seguro D\&O.

Como exposto no item 2.1.1 acima, além de sua função primordial compensatória, o regime de responsabilidade civil desempenha outro papel: a prevenção de danos.

$\mathrm{Na}$ visão de alguns autores, a celebração do seguro de responsabilidade civil poderia desestimular a adoção de uma conduta diligente pelo segurado, haja vista que, assegurada a cobertura do evento danoso pela seguradora, o segurado não sofreria os efeitos patrimoniais de sua responsabilização.

De outro modo, entende-se que o risco de suportar os prejuízos econômicos decorrentes de eventual dano causado a terceiro representaria um estímulo ao acusado para a adoção de um padrão de comportamento mais cuidadoso e consciente.

Ao mesmo tempo, resguardados sob a garantia de que eventuais prejuízos decorrentes da responsabilização dos administradores não recairiam sobre o patrimônio da companhia, sendo suportados pela seguradora em razão da contratação de cobertura side $B$ e/ou side $C$, os demais administradores e conselheiros fiscais teriam reduzidos incentivos para fiscalizar a atuação dos diretores.

No entanto, ao analisar a base econômica e o método de precificação do seguro de responsabilidade civil, bem como os procedimentos de avaliação de risco que antecedem a sua contratação, verifica-se que, além de adotar justificativa simplista, que reduz a racionalidade das decisões e do comportamento dos indivíduos a uma lógica utilitarista, a crítica dirigida a 
esta modalidade de seguro desconsidera alguns elementos fundamentais que podem ser apontados como limitadores do risco moral.

Em primeiro lugar, destaca-se que a própria estrutura técnicoeconômica das operações de seguro evidencia que o ônus de reparação não é simplesmente transferido à seguradora, sem qualquer relação com o segurado, mas sim diluído entre diversos "agentes potencialmente lesivos", cujas contribuições individuais (prêmio) serão destinadas a indenizar os prejuízos causados a terceiros por alguns integrantes desta mutualidade.

Nota-se, portanto, que há uma relação de equivalência entre os prêmios puros pagos pelos segurados e o custo global das indenizações que, eventualmente, serão devidas pelo segurador em caso de concretização do sinistro, de modo que o aumento do valor total das indenizações será sentido por todos os segurados, de quem se exigirá uma contribuição maior $^{205}$.

A intensificação dos sinistros e, por conseguinte, o aumento do montante total de indenizações pago pelo segurador importa não somente a elevação dos custos totais do seguro, como também influencia a avaliação do segurado ou, no caso do seguro de responsabilidade civil de administradores, da própria companhia tomadora, cujo perfil de risco será considerado na fixação do prêmio devido à seguradora e, até mesmo, para a própria aceitação do seguro.

Conforme exposto no item 1.3.3. acima, via de regra, em razão da característica do seguro como contrato de adesão, a avaliação de risco realizada pela seguradora é muito limitada, dependendo, em grande medida, das informações prestadas pelo próprio segurado a partir do preenchimento

\footnotetext{
205 Nesse sentido, Anderson Schreiber esclarece que "o ônus da reparação é apenas aparentemente transferido à seguradora, uma vez que o custo global das indenizações pagas reflete-se, invariável e continuamente, sobre o preço dos seguros" (SCHREIBER, Anderson. Op. Cit. p. 242).
} 
de formulários e das respostas aos questionamentos formulados previamente pelo segurador ${ }^{206}$.

No entanto, no que diz respeito ao seguro D\&O, essa fase précontratual é mais detalhada, conduzindo-se uma análise prévia das características particulares da companhia tomadora do seguro (estrutura societária, importância das operações econômicas envolvidas, existência ou não de holdings, segmento de atuação no mercado, saúde financeira, etc.), bem como uma avaliação do histórico profissional dos administradores beneficiários do seguro ${ }^{207}$.

Todos esses elementos serão considerados para o cálculo do prêmio, razão pela qual as companhias contam com um incentivo adicional para desenvolver e adotar boas práticas de governança corporativa, de modo a reduzir a sua exposição a riscos e, por conseguinte, obter melhores condições na contratação do seguro.

Acrescenta-se, ainda, que a própria seguradora emprega mecanismos alternativos de estímulo à conduta cuidadosa por parte do segurado, visto que tem interesse direto na redução dos sinistros, de forma a reduzir os seus custos $^{208}$.

Nesse sentido, destaca-se que, da mesma forma que o perfil do segurado pode demonstrar uma maior exposição a riscos e, por consequência, justificar um aumento no valor da contribuição devida à

\footnotetext{
206 "In addition, the D\&O insurer makes use of application forms, through which attempts are made to gather supplemental information on the company and its directors and officers. The application forms request, for instance: the financial data (turnover, result, assets, liabilites, etc.), as well as information on the shareholders and the percentage of their shares, the structure of the legal entity, subsidiares, the corporate governance structure, the nature of the activities, the history of the legal entity and its participations, previous and anticipated mergers and acquisitions, expected changes in profitability, activities in North America, listings, audits and audit opinions, the desired insured amount, previously concluded $D \& O$ insurance policies and previously filed and/or anticipated claims vis-à-vis directors". (WETERINGS, Wim. Op. cit. p. 9). ${ }^{207}$ MAIA, Roberta Mauro Medina; BURMAN, Leonardo Joseph. Op. Cit. p. 135

${ }^{208}$ Nesse sentido, Marília de Cara aponta estudo recente na Universidade de Chicago (EUA), que verificou que a acirrada concorrência no mercado securitário e o incentivo de contenção de custos após o pagamento dos prêmios teriam estimulado as seguradoras a desenvolver mecanismos de controle de riscos por vezes mais eficientes do que os próprios órgãos reguladores ou o judiciário. (CARA, Marília de. Op. Cit. p. 122)
} 
seguradora, a ausência ou baixa incidência de seu histórico lesivo pode lhe assegurar alguns benefícios concedidos pela seguradora, tal como bônus e alíquotas diferenciados.

Deixando de lado a perspectiva econômica, vale ressaltar as referências mencionadas por Marília de Cara quanto aos estudos realizados recentemente apontando a existência de mecanismos efetivos de controle do risco moral pelas seguradoras ${ }^{209}$. As referidas pesquisas demonstram que a atuação da seguradora no monitoramento da conduta do segurado e no acompanhamento da saúde financeira da companhia tomadora poderia conter o risco moral.

Especial destaque merece a pesquisa desenvolvida por Wim Weterings $^{210}$. Muito embora reconheça o risco moral como uma realidade nesta modalidade de seguro, que demanda especial atenção, o autor identifica a partir da experiência do mercado securitário holandês dois instrumentos que podem ser utilizados para reduzir este risco $^{211}$.

O primeiro instrumento indicado por Wim Weterings seria o monitoramento da companhia e dos segurados ao longo da execução do contrato de seguro e o aumento proporcional do prêmio a depender da conduta por eles adotada e de seu perfil de risco ${ }^{212}$. Nada muito diferente das alternativas apresentadas nos demais estudos mencionados acima.

\footnotetext{
${ }^{209}$ Ibidem, pp. 121-122.

${ }^{210}$ WETERINGS, Wim. Op. Cit.

211 "There are various instruments for insurers to reduce this moral hazard. It is importante for $D \& O$ insurers to use those instruments as much as possible and to reduce the moral hazard as much as possible. If that does not happen, the incentives from liability law to take preventive measures and act carefully will be undermined too much" (Ibidem. p.2).

${ }^{212}$ No entanto, tal como ressaltado por Wim Weterings, as companhias seguradoras enfrentam algumas limitações no monitoramento da companhia tomadora e de seus administradores. Isso porque, em um mercado competitivo, a solicitação de informações mais detalhadas e a formulação de exigências para a contratação do seguro podem levar a companhia tomadora a procurar outra seguradora. Além disso, os mecanismos de fiscalização envolvem altos custos, que deverão ser suportados pela seguradora. Soma-se a isso o fato de que, naturalmente, há uma assimetria informacional entre o segurado e a seguradora, que, não obstante o esforço de monitoramento, sempre enfrentará dificuldades para identificar todos os riscos aos quais está exposto o segurado.
} 
Chama atenção, no entanto, o segundo instrumento proposto pelo autor: a exposição parcial da companhia tomadora e dos segurados ao risco objeto do contrato de seguro. Para tanto, a seguradora pode adotar diferentes medidas, tal como a limitação da cobertura do seguro, a fixação de um limite máximo de cobertura ou a previsão de franquia em determinadas hipóteses.

Na visão do autor, esta última medida teria especial importância, uma vez que, neste caso, a exposição parcial aos efeitos econômicos de eventual responsabilização serviria de estímulo ao administrador para a adoção de uma conduta diligente, mas, ainda assim, resguardaria, em grande medida, o seu patrimônio dos danos decorrentes da sua atuação na administração da companhia $^{213}$.

No que diz respeito à nova regulamentação do seguro D\&O editada pela SUSEP, é possível identificar a adoção de alguns desses instrumentos. Nesse sentido, merecem destaque as hipóteses de exclusão delimitadas pela Circular SUSEP n’ 553/2017, em especial a não cobertura de "atos ilícitos dolosos, isto é, praticados pelo segurado comprovadamente com dolo ou culpa grave", nos termos da definição de "fato gerador". Como exposto acima, a própria jurisprudência do STJ reconhece a exclusão de cobertura nos casos em que a atuação do administrador busque auferir benefícios pessoais e/ou esteja desvinculada da gestão social (REsp n $\left.{ }^{\circ} 1.601 .555\right)$.

Desse modo, não há que se falar que a contratação do seguro levaria o administrador a adotar, propositadamente, conduta descuidada e negligente, uma vez que é expressa a exclusão de cobertura de atos dolosos.

Acrescenta-se, ainda, que a Circular SUSEP n ${ }^{\text {o }}$ 553/2017 prevê não apenas um limite máximo agregado (LMA), como também um limite

\footnotetext{
213 "After all, part of the defense costs and the possible compensation to be paid, when the insured risk occurs, is not borne by the insurer. The director then still receives incentives to act with due care and not to develop any entrepreneurial risks that are irresponsible or more than normal. This reduces the moral hazard." (Ibidem, p. 12).
} 
máximo de indenização por cobertura (LMI) e, facultativamente, um limite máximo de garantia (LMG).

No que diz respeito à previsão de franquia no seguro $\mathrm{D} \& \mathrm{O}$, segundo Clara Beatriz Lourenço de Faria, tal estipulação não é adotada usualmente nas apólices brasileiras ${ }^{214}$.

Outro elemento fundamental que muitas vezes é desconsiderado na análise do risco moral do seguro $\mathrm{D} \& \mathrm{O}$ diz respeito às esferas de responsabilização do administrador.

Conforme exposto no capítulo 2 deste trabalho, o administrador pode ser responsabilizado por sua atuação na gestão social não apenas na esfera cível, como também nas esferas criminal e administrativa. Nestes casos, a responsabilização do acusado importa não apenas a condenação ao pagamento de indenização ou multa pecuniária, como também a aplicação de penalidades restritivas de direito. Na esfera administrativa sancionadora, por exemplo, caso o administrador venha a ser responsabilizado pela prática de conduta que configure infração grave, nos termos do artigo $11, \S 3^{\circ}$ da Lei $n^{\circ} 6.385 / 76$, poderá ser aplicada a penalidade de inabilitação temporária para o exercício dos cargos de administração.

Ressalta-se que, mesmo na esfera cível, o fato de a seguradora suportar o ônus econômico de eventual condenação, não exclui a responsabilidade do administrador.

Ainda que afastados os efeitos econômicos, é certo que o reconhecimento da responsabilidade ou, até mesmo, a simples propositura de ações em face do administrador podem afetar a sua reputação, sua empregabilidade e sua habilitação para ocupar cargos na administração de companhias.

${ }^{214}$ FARIA, Clara Beatriz Lourenço de. Op. Cit. p. 97. 
Por todo o exposto, conclui-se que o risco moral ao qual se associa o seguro de responsabilidade civil de administradores não seria irremediável a ponto de desaconselhar a contratação desta modalidade de seguro, haja vista não somente a existência de instrumentos aptos a mitigá-lo, os quais, em grande parte, podem ser adotados pela própria seguradora, como também a importância deste seguro para a conciliação dos diferentes interesses envolvidos na gestão social, conforme exposto no item 3.1. deste capítulo. 


\section{CONCLUSÃO}

O contrato de seguro pode ser compreendido como um instrumento voltado à prevenção de riscos e à administração dos efeitos danosos dele decorrentes.

No caso do seguro de responsabilidade civil de administradores, o risco que se busca afastar por meio da contratação da cobertura securitária decorre da atuação do administrador na condução dos negócios sociais, que, além de envolver alto grau de incerteza, característica inerente ao processo de tomada de decisões, poderá produzir efeitos para além do âmbito interno da própria companhia, repercutindo na esfera de interesses de terceiros.

Conforme se procurou demonstrar ao longo do presente trabalho, grande parte dos riscos aos quais está exposto o administrador advém de sua responsabilização nas esferas cível, administrativa e criminal, sem prejuízo dos efeitos decorrentes da apuração de responsabilidade em outros ramos do direito.

Identificaram-se, portanto, três situações representativas de riscos ao administrador: (i) a propositura de ação judicial para reparação de danos; (ii) a instauração de processo administrativo sancionador no âmbito da CVM para apuração da conduta do administrador à luz da legislação societária e do mercado de valores mobiliários; e (iii) a abertura de processo criminal para avaliar a incidência da conduta do administrador em algum tipo penal.

Ainda assim, a responsabilidade do administrador nestas hipóteses sofre uma limitação importante: a necessidade de verificação da culpa lato sensu. Seja para fins de reparação dos danos causados a terceiros em eventual ação de responsabilidade civil, seja para apuração da conduta do administrador em processo de caráter sancionador exige-se o elemento subjetivo.

Nos termos descritos no capítulo segundo deste trabalho, o ato regular de gestão, que pressupõe a atuação do administrador dentro dos limites de 
suas atribuições e em observância aos preceitos legais e estatutários, não ensejará a sua responsabilização pessoal, ainda que dele advenham prejuízos à companhia, aos seus acionistas ou a terceiros.

Por sua vez, nos casos de atuação fora dos limites de discricionariedade conferidos por lei ou pelo estatuto ou, ainda, em caso de falta de diligência, desvio de poder, conduta desleal ou outro descumprimento de dever legal ou estatutário, verifica-se a responsabilidade pessoal do administrador, do que decorrerá, eventualmente, condenação à reparação dos danos causados, imposição de penalidade na esfera administrativa ou, ainda, a celebração de termo de compromisso por meio da assunção de obrigações pelo administrador, cujo cumprimento levará a extinção do processo sancionador.

Todos esses resultados tem o potencial de impactar negativamente o patrimônio pessoal do administrador, em razão dos recursos despendidos com custos de defesa, com o pagamento da indenização ao sujeito lesado ou da multa fixada em processo sancionador ou com o cumprimento de obrigação pecuniária assumida pelo administrador para celebração de termo de compromisso.

Deste modo, é fundamental que a cobertura securitária oferecida nas apólices D\&O comercializadas pelas seguradoras seja capaz de garantir, da forma mais ampla possível, o patrimônio pessoal do administrador face aos riscos decorrentes de sua atuação na gestão da companhia.

Conforme exposto no capítulo terceiro deste estudo, diante das inúmeras críticas dirigidas ao primeiro normativo editado pela SUSEP, o esforço conjunto desta entidade reguladora e de diferentes agentes do mercado securitário no sentido de rediscutir as disposições aplicáveis ao seguro D\&O parece ter gerado resultados positivos com a edição da Circular SUSEP $n^{\circ} 553 / 2017$, os quais só poderão ser confirmados com o tempo, 
conforme forem sendo submetidas a registro as apólices sob as novas condições.

A Circular SUSEP n ${ }^{\circ}$ 553/2017 prevê que a cobertura do seguro D\&O abarcará os custos de defesa, as indenizações e os acordos celebrados com a anuência da seguradora decorrentes de reclamação nas esferas cível, penal e administrativa, que representariam boa parte dos riscos aos quais estão expostos os administradores, conforme ressaltado acima.

De especial importância foram os ajustes promovidos quanto à garantia dos custos de defesa, os quais eram tratados pela Circular SUSEP $n^{0}$ 541/2016 como objeto de cobertura adicional e que passaram a ser incluídos na cobertura básica do seguro, em linha com as práticas de mercado, bem como a pacificação da controvérsia acerca da cobertura de multas e penalidades cíveis e administrativas, superando entendimento manifestado anteriormente pela SUSEP com base em parecer emitido pela Procuradoria de Assuntos Societários e Regimes Especiais.

A possibilidade de cobertura de multas e penalidades administrativas atende em especial os interesses de administradores de companhias abertas, os quais se encontram expostos aos riscos decorrentes da atuação sancionadora da CVM, sem prejuízo da atuação de outras entidades administrativas, cuja competência não foi objeto de análise no presente trabalho.

A alteração da previsão normativa no sentido de possibilitar a inclusão de referências à legislação estrangeira nas apólices cujo âmbito geográfico de cobertura não se restrinja ao território nacional reabre a possibilidade de contratação do seguro D\&O com cobertura internacional, notadamente por companhias cujos valores mobiliários estejam listados em outras bolsas de valores e companhias com operações no exterior.

Verificou-se, portanto, que para estes riscos principais decorrentes da responsabilização do administrador nas esferas cível, administrativa e 
penal, a Circular SUSEP n ${ }^{\circ}$ 553/2017 parece se alinhar, em grande medida, às práticas de mercado e aos interesses das companhias tomadoras e seus administradores.

Contudo, em razão da limitação conferida ao conceito de "reclamação", que faz menção apenas aos processos administrativos e às ações cíveis e penais, resta dúvida quanto à cobertura dos riscos advindos da responsabilização do administrador em outras esferas do direito (trabalhista, consumerista, tributária, etc.), havendo a possibilidade de eles virem a ser objeto de cobertura adicional.

Há ainda outros "termos definidos" que suscitam maiores dificuldades na interpretação do normativo à luz das práticas de mercado. No entanto, tendo em vista a previsão da Circular SUSEP n ${ }^{\circ}$ 553/2017 de que poderão ser adotadas definições equivalentes nas apólices do seguro $\mathrm{D} \& \mathrm{O}$, a possibilidade de alteração da cobertura básica pela própria seguradora dependerá da interpretação conferida pela SUSEP a este dispositivo e da discricionariedade conferida às seguradoras para elaboração dessas definições equivalentes.

Dito isso, conclui-se que, em linhas gerais, a Circular SUSEP $n^{\circ}$ 553/2017 parece abarcar os principais riscos aos quais estão expostos os administradores de sociedades anônimas, observadas as ressalvas quanto à cobertura de riscos advindos de outras esferas do direito. 


\section{BIBLIOGRAFIA}

ABRASCA. Abrasca e FenSeg debatem Circular 541 da SUSEP que regula seguros $R C$ e $D \& O$. In: Sistema de Informação Abrasca às Companhias Abertas - SIA \& CIA. Edição semanal. Número 1331. 10 p. 12/12/2016. Disponível em: http://www.abrasca.org.br/Uploads/siacia/1385 _Sia_Cia_1331.pdf. Acesso em: 10 de outubro de 2017.

ADAMEK, Marcelo Vieira Von. Responsabilidade civil dos administradores de S/A (e as ações correlatas). São Paulo: Saraiva, 2009.

ALVIM, Pedro. O Seguro e o Novo Código Civil. Rio de Janeiro: Forense, 2007.

AMARO, Anderson de Souza. O seguro de responsabilidade civil dos administradores. In: Revista de Direito Empresarial. Belo Horizonte: vol. 2, mar.-abr. 2014.

BITTAR, Carlos Alberto. Responsabilidade dos Administradores de Sociedades Anônimas. In: Doutrinas Essenciais de Responsabilidade Civil. Vol. III. São Paulo: Out.2011.

BRAGA, Julia de Castro Tavares. As novas regras do seguro $D \& O$ no Brasil. Sincor-RJ. 29/06/2017. Disponível em: https://www.sincorrj.org.br/single-post/2017/06/29/As-novas-regras-do-seguro-DO-no-Brasil. Acesso em: 08 de novembro de 2017.

BRIGAGÃO, Pedro Henrique Castello. A Administração de Companhias e a Business Judgment Rule. São Paulo: Quartier Latin, 2017.

BUENO, Denise. Lava-Jato provoca mudanças no $D \& O$. In: Valor Econômico. Edição 21 de março de 2017. Disponível em: http://www.bmalaw.com.br/arquivos/Artigos/HENERIQUE_LavaJato\%20provoca\%20mudan\%C3\%A7as\%20no\%20DO.pdf. Acesso em: 08 de novembro de 2017. 
BULGARELLI, Waldirio. Apontamentos sobre a responsabilidade dos administradores das companhias. In: Revista de Direito Mercantil, Industrial, Econômico e Financeiro, v. 22, nº 50, abr./jun. 1983, p. 75.

CAMPOS, Luiz Antônio de Sampaio. Deveres e responsabilidades. In FILHO, Alfredo Lamy; PEDREIRA, José Luiz Bulhões (org). Direito das companhias. $2^{\mathrm{a}}$ ed. Rio de janeiro: Forense, 2017.

CARA, Marília de. A aplicabilidade do seguro de responsabilidade civil de administradores e diretores no âmbito da administração das companhias. 142 p. Dissertação de Mestrado, USP, 2013.

CARVALHOSA, Modesto. Responsabilidade civil de administradores e de acionistas controladores perante a Lei das S/A. In: Revista dos Tribunais, vol. 699, jan. 1994.

DIAS, José de Aguiar. Da Responsabilidade Civil. 12a ed. Rio de Janeiro: Lumen Juris, 2012.

EIZIRIK, Nelson. Responsabilidade civil e administrativa do diretor de companhia aberta. In: Revista de Direito Mercantil, Industrial, Econômico e Financeiro. Ano XXIII. nº 56, out.-dez., 1984.

EIZIRIK, Nelson. (et. al.). Mercado de capitais - regime jurídico. $3^{\text {a }}$ Ed. Rio de Janeiro: Renovar, 2011.

EIZIRIK, Nelson. A Lei das S/A Comentada. Vol. III-2aed.. Artigos 138 a 205. São Paulo: Quartier Latin, 2015.

FARIA, Clara Beatriz Lourenço de. $O$ seguro $D \& O$ e a proteção ao patrimônio dos administradores. $2^{\mathrm{a}}$ ed.. São Paulo: Almedina, 2015.

FIGUEIRA, Fábio; PICCOLO, Andrea. $O$ seguro $D \& O$ e a Circular SUSEP 553/2017. In: Revista Opinião.Seg, Editora Roncarati, no 14, julho 2017, p. 157. Disponível em: http://www.veirano.com.br/upload/content_att 
achments/509/Fabio_Figueira_Andrea_Piccolo_Opiniao_14 original.pdf. Acesso em: 08 de novembro de 2017.

FOLEGO, Thais. D\&O mais caro. In: Capital Aberto, 29 de outubro de 2017. Disponível em: http://www.multclipp.com.br/verNoticia.aspx?n=6iM 2WNehP1k\%3d\&e=I6sWPfMdnf4\%3d. Acesso em: 03 de novembro de 2017.

FRANCO, Vera Helena de Mello. A operação de seguros e sua qualificação jurídica. In: Revista de direito mercantil, industrial, econômico, financeiro no 67. Jul.-Set./1987, Revista dos Tribunais, pp. 3956.

GALRÃO, Gustavo; SALVADOR, Dinir; CICARELLI, Márcia. Café Com Seguro D\&O - Circular 553 - Ansp. Disponível em: http://www.anspnet.org.br/site/galerias-de-videos/cafe-com-seguro-docircular-553-ansp/. Acesso em: 08 de novembro de 2017.

GATTAZ, Luciana de Godoy Penteado. A responsabilidade civil dos administradores de companhias aberas não financeiras e o seguro $D \& O$. In: Revista de Direito Bancário e do Mercado de Capitais, ano 19, vol. 74, out.-dez, 2016.

GOLDBERG, Ilan. Confiança, cooperação, máxima boa-fé e o contrato de seguro. Rio de Janeiro: Revista Juridica de Seguros, 2017.

GUERREIRO, José Alexandre Tavares. Responsabilidade dos administradores de sociedades anônimas. In: Revista de Direito Mercantil, Industrial, Econômico, Financeiro, n. 42, abr./jun. 1981.

GUERREIRO, Marcelo da Fonseca. Seguros Privados: Doutrina, legislação e jurisprudência. $2^{\mathrm{a}}$ ed. Rio de Janeiro: Forense Universitária, 2004. 
MACHADO, Hugo de Brito. Responsabilidade Penal no Âmbito das Empresas. In: SALOMÃO, Heloisa Estelita (org). Direito Penal Empresarial. São Paulo: Dialética, 2001.

MAIA, Roberta Mauro Medina; BURMAN, Leonardo Joseph. Apontamentos sobre o seguro de responsabilidade civil para atos de gestão de administradores ou diretores de empresas $(D \& O)$. In: Revista Trimestral de Direito Civil. Rio de Janeiro. Vol. 30, abr./jun. 2007, p.135.

MELLO, Sergio Ruy Barroso de. O Seguro de Responsabilidade Civil na Modalidade $D \& O$. In: Revista Jurídica de Seguros, ${ }^{\circ} 2$. Rio de Janeiro: CNseg, Maio de 2015.

MIRAGEM, Bruno; CARLINI, Angélica. Direitos dos Seguros: Fundamentos de Direito Civil. Direito Empresarial e Direito do Consumidor. São Paulo: Revista dos Tribunais, 2014.

PARENTE, Flávia. O dever de diligência dos administradores de sociedades anônimas. Rio de Janeiro: Renovar, 2005.

PARENTE, Norma Jonssen. Limites da responsabilidade dos administradores pela indenização de prejuízos. In: Revista de Direito Bancário e do Mercado de Capitais, vol. 31, jan. 2006.

PEREIRA, Caio Mário da Silva. Instituições de Direito Civil. Volume III $17^{\mathrm{a}}$ ed. Rio de Janeiro: Forense, 2013.

RIBEIRO, Amadeu Carvalhaes. Direito de Seguros: Resseguros, Seguro Direto e Distribuição de Serviços. São Paulo: Atlas, 2006.

RODRIGUES, Ana Carolina. A Responsabilidade Civil e o Seguro D\&O. In: Revista de direito Bancário e do Mercado de capitais. Vol.58. São Paulo: Revista dos Tribunais, 2012. 
SANTOS, Alexandre Pinheiro do; OSÓRIO, Fábio Medina; WELLISCH, Julya Sotto Mayor. Mercado de Capitais: Regime sancionador. São Paulo: Saraiva, 2012.

SANTOS, Alexandre Pinheiro dos. Por que defender os termos de compromisso no mercado de capitais?. Espaço Jurídico BM\&FBOVESPA, jan. 2010.

SCHREIBER, Anderson. Novos paradigmas da responsabilidade civil: da erosão dos filtros da reparação à diluição dos danos. $5^{\mathrm{a}}$ ed. São Paulo, Atlas, 2013.

STJ, REsp n ${ }^{\circ}$ 1.601.555, Terceira Turma, Min. Rel. Ricardo Villas Bôas, Brasília, 14 de fevereiro de 2017.

STJ, REsp 962.230-RS, Rel. Min. Luis Felipe Salomão, Brasília, 08 de fevereiro de 2012.

TJSP, Apelação Cível n ${ }^{\circ}$ 0172250-84.2010+8.26.0100, 10ª Câmara de Direito Privado, Des. Rel. Roberto Maia, São Paulo, 25 de junho de 2013. TJSP, Apelação Cível nº1087421-51.2013.8.26.0100, 1ª Câmara de Direito Empresarial, Des. Rel. Manoel de Queiroz Pereira Calças, São Paulo, 15 de março de 2017.

TJSP, Apelação Cível no 1095579-95.2013.8.26.0100, 1ª Câmara de Direito Privado, Des. Rel. Rui Cascaldi, São Paulo, 23.02.2016.

TJSP, Apelação n ${ }^{\mathrm{o}}$ 0081391-51.2012.8.26.0100, 4 ${ }^{\mathrm{a}}$ Câmara de Direito Privado, Des. Rel. Hamid Bdine, São Paulo, 13 de agosto de 2015.

TZIRULNIK, Ernesto. O futuro do seguro de responsabilidade civil. In: JUNIOR, Nelson Nery; NERY, Rosa Maria de Andrade (org.). Responsabilidade Civil. Volume II - Direito de obrigações e direito negocial. São Paulo: Revista dos Tribunais, 2010. 
TZIRULNIK, Ernesto; CAVALCANTI, Flávio de Queiroz B.; PIMENTEL, Ayrton. $O$ contrato de seguro de acordo com o código civil brasileiro. $3^{\mathrm{a}}$ ed. São Paulo: Roncarati, 2016.

WETERINGS, Wim. Directors' \& Officers' liability, $D \& O$ insurance and moral hazard: more control of moral hazard by $D \& O$ insurers needed to increase the incentives of directors and supervisory board members, 2012. Disponível em: http://ssrn.com/abstract=2153129. Acessado em 04 de outubro de 2017. 